\title{
Ze studiów nad dziejami podwarszawskich rezydencji. Zabudowania w otoczeniu pałacu Brühlów w Młocinach (od połowy XVIII w.).
}

Słowa kluczowe: pałac, architektura ogrodowa, rezydencje nowożytne, Warszawa
Key words: palace, garden architecture, residences in Modern Times, Warsaw

Pałac w podwarszawskiej wsi Młociny ${ }^{1}$, zbudowany ok. połowy XVIII stulecia, stanowił część nowożytnego, rozległego założenia obejmującego, prócz najbliższego otoczenia (w tym parku, oficyn i innych zabudowań gospodarczych), także m.in. nadwiślańskie ogrody z ozdobnymi pawilonami, zwierzyniec, karczmę oraz wiatrak. Był to najbardziej wysunięty na północ na linii Skarpy Warszawskiej tego typu zespół rezydencjonalny². W tej rozbudowanej formie istniał on dość krótko; począwszy od schyłku XVIII w. zaczął bowiem ulegać przekształceniom, które powodowały jego postępującą degradację poprzez zanik tworzących go poszczególnych części, a tym samym pierwotnej koncepcji architektonicznej, oraz w wyniku zmniejszania się zajmowanego przezeń obszaru (ryc. 1).

Niniejszy artykuł dotyczy przede wszystkim budynków i budowli wchodzących w skład programu użytkowego i kompozycyjnego młocińskiego założenia ogrodowego, pełniących funkcje mieszkalne, gospodarcze $e^{3}$ bądź dekoracyjne, służące wypoczynkowi i rozrywce. Zebrano dostępne dane na ten temat, $\mathrm{w}$ tym zawarte w źródłach pisanych i ikonograficznych (m.in. na archiwalnych mapach i zdjęciach lotniczych), uzupełnione wynikami nowszych badań archeologicznych ${ }^{4}$ — wykopaliskowych (przeprowadzonych w 2010 r.) i nieinwazyjnych (analiza numerycznych modeli terenu w oprogramowaniu GIS wykonana w 2017 r. ${ }^{5}$ ).

1 Młociny zostały przyłączone do stolicy w 1951 r. Do tego czasu były wsią położoną na północ od Warszawy. Obecnie pałac jest w granicach miasta, w dzielnicy Bielany, przy ul. Muzealnej 1. Figuruje w rejestrze zabytków pod numerem 646/1, decyzją z 1 lipca 1965 r. Istniejącymi i podlegającymi ochronie elementami tego dawnego założenia są: korpus pałacu, dwie oficyny oraz niewielki obszar dawnego parku. Od 2010 r. nie podejmowano tam prac badawczych ani remontowych. Obiekt stopniowo niszczeje.

${ }^{2}$ Rezydencje z ogrodami na tarasach nad Wisłą wznoszono od połowy XVI stulecia (z tego czasu pochodzą np. królewskie wille przy Krakowskim Przedmieściu i w Ujazdowie), lecz najwięcej ich powstało w ciągu XVIII w. i było w posiadaniu magnatów. To m.in.: Bażantarnia (Natolin), Rozkosz, Królikarnia, Mon Coteau, Belweder, Zamek Ujazdowski, Na Książecem, a także Dynasy, Villa Regia, rezydencje Koniecpolskiego i Kazanowskiego oraz Marymont (por. np. Putkowska J. 2016; Napieralski M. 2017). Podstawowym walorem lokalizacji na wzniesieniu był malowniczy wiślany pejzaż oraz możliwość rozplanowania osi widokowych z daleką perspektywą (np. Morawińska A. 1977, s. 39). Rozwiązania przestrzenne tych ogrodów były zróżnicowane, a zależały od rodzaju, wielkości i położenia posiadłości (Majdecki L. 1973, s. 231).

3 Majdecki L. 2007, s. 459, hasło: Architektura ogrodowa.

4 O zastosowaniu metod archeologicznych we współczesnych badaniach zabytkowych parków i ogrodów, por. np. Dix B. 2016; Sourcebook. 2013.

5 Archiwalną kartografię porównano z czterema rodzajami danych pobranych z serwisu Geoportal: ortofotomapą, numerycznymi modelami terenu (warstwy ISOK-Cieniowanie i ISOK-Hipsometria o dynamicz- 


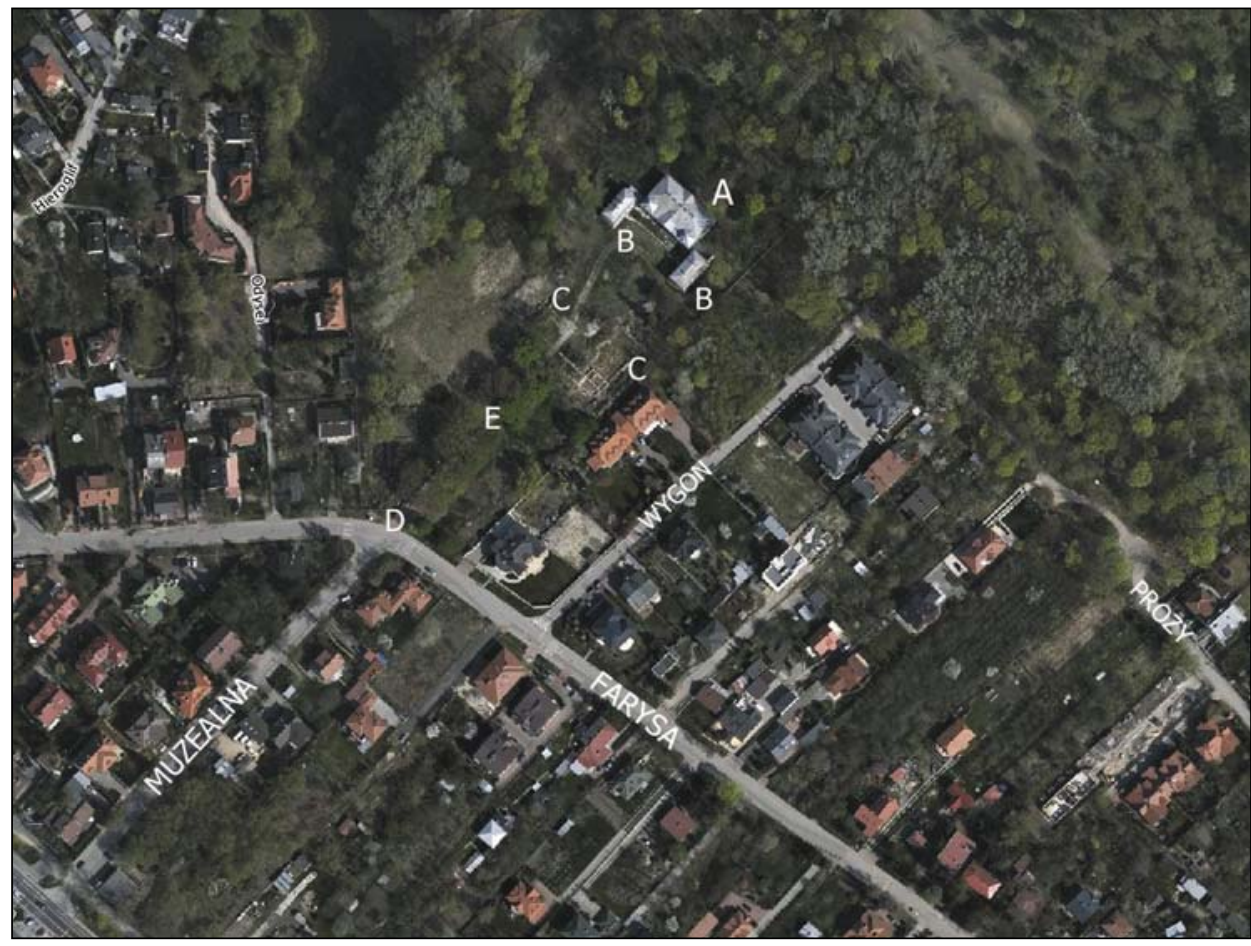

Ryc. 1. Fragment współczesnych Młocin z częścią dawnego założenia pałacowo-ogrodowego, zdjęcie lotnicze, 2011 r.: A — pałac; B — oficyny pierwsze; C — relikty zabudowań odsłonięte podczas badań archeologicznych w 2010 r.; D — lokalizacja współczesnej bramy i reliktów bramy-wjazdu z drugiej połowy XVIII w.; E — aleja grabowa (fot. nieznany, portal Urzędu m.st. Warszawy; za: Muzealna. 2011; oprac. W. Bis)

Fig. 1. A part of contemporary Młociny, with a fragment of the former palace-and-garden complex, an aerial photograph, $2011 \mathrm{r}$ : A - the palace; B - the outhouses closer to the palace; $\mathrm{C}$ - relics of buildings excavated in 2010; D - the contemporary gate and relics of the gate from the $2^{\text {nd }}$ half of the 18th c.; E - an alley of hornbeams (photographer unknown; the portal of the Municipal Council of Warsaw; after: Muzealna. 2011; compiled by W. Bis)

Korelacja informacji z tych rozmaitych kategorii przekazów umożliwiła scharakteryzowanie poszczególnych obiektów oraz określenie ich losów — od projektu, przez realizację, po stopniowe zniszczenie. Pozwoliła także na lokalizację i identyfikację części z nich, niegdyś istniejących, obecnie zaś niezachowanych w terenie, przede wszystkim dawnych oficyn, bramy oraz niektórych pawilonów. Poza tym wskazano potencjał tkwiący w dalszych badaniach tego interesującego, wieloczłonowego zespołu.

nej skali barw) oraz danymi o charakterze katastralnym (granice i numery działek). ISOK — Informatyczny System Osłony Kraju to projekt rządowy uruchomiony w 2009 r., którego głównym celem było stworzenie jednolitego systemu informatycznego służącego osłonie społeczeństwa, gospodarki oraz środowiska naturalnego przed szczególnymi zagrożeniami, m.in. powodziami. Dla niektórych obszarów opracowano dane wysokościowe pozyskane za pomocą lotniczego skanowania laserowego. Numeryczne modele terenowe udostępniono w serwisie geoportal.gov.pl. Mogą one być z powodzeniem stosowane w archeologii terenowej, należy jednak uwzględnić niską rozdzielczość punktów numerycznych modeli terenu, por. Maślanka M., Wężyk P. 2015. 
Założeniu w Młocinach poświęcono kilka odrębnych prac z zakresu historii, historii sztuki i archeologii ${ }^{6}$. Informacje o tym zamieszczono także w publikacjach o charakterze popularnonaukowym ${ }^{7}$. Do najistotniejszych źródeł do dziejów tego założenia, z uwagi na informacje i dokumentację elementów architektonicznych, szczególnie tych współcześnie niezachowanych, należą relacje z epoki, w tym pochodzące z roku 1765 - inwentarz (zawierający skrótowy opis wyglądu pałacu oraz znajdujących się w pobliżu zabudowań) (por. Inwentarz. 1765) ${ }^{8}$ oraz doniesienia w prasie warszawskiej i toruńskiej na temat wizyty w Młocinach króla Stanisława Augusta Poniatowskiego, w których wymieniono obiekty odwiedzane wówczas przez monarchę9. Poza tym spisane i wydane w 1784 r. przez Szymona Bogumiła Zuga informacje o ogrodzie młocińskim (w tym o niektórych elementach całego założenia $i$ ich funkcji) ${ }^{10}$, a także wzmianki we wspomnieniu o Alojzym Fryderyku Brühl'u, zamieszczone w zbiorze Friedricha Schlichtegrolla z 1795 r. ${ }^{11}$ Dla podejmowanych rozważań nieodzowne są też mapy, plany i widoki z drugiej połowy XVIII i pierwszej ćwierci XIX w. stanowiące dokumentację projektową albo oddające rzeczywisty wygląd lub rozplanowanie ówczesnego kompleksu pałacowo-parkowego ${ }^{12}$. $\mathrm{Z}$ kolei dla określenia zmian $\mathrm{w}$ jego rozkładzie przestrzennym i zasięgu oraz stopnia destrukcji istotne są wybrane przedstawienia ikonograficzne uwzględniające Młociny powstałe w XIX i w pierwszej połowie XX w. ${ }^{13}$

Spośród faktów z historii młocińskiego założenia zasygnalizujemy najważniejsze dla podejmowanych tu rozważań, zwłaszcza odnośnie do osób i czynników, które przyczyniły się do powstania bądź do dekompozycji poszczególnych jego składowych. Inicjatorem budowy pałacu był hrabia Henryk von Brühl (1700-1763), saski arystokrata, pełniący funkcję pierwszego ministra na dworze królów Augusta II Mocnego i Augusta III z dynastii Wettinów ${ }^{14}$. Przyjmuje się, że to w efekcie jego inwestycji w latach pięćdziesiątych XVIII w. (zapewne pomiędzy 1757 a 1758 r.) wzniesiony został późnobarokowy korpus pałacu. Za jego projektanta uważa się

${ }^{6}$ Drukiem ukazały się: Sokołowska-Grzeszczyk K. 1962; Bis M., Bis W. 2011-2012. Sporo informacji na ten temat także w: Hentschel W. 1967, t. I, s. 336-340 (podrozdział: Młociny); t. II, [ryc.] 453-457; Kwiatkowski M. 1971, s. 83-86, 261-263, 331; Putkowska J. 2016, s. 170-175, 456-458. Pozostałe to niepublikowane opracowania w formie maszynopisów: Pustoła-Kozłowska E. 1991; Siuder H. 1974; Kozłowska B. 2005 ; Pape D. 2008; Bis W. 2010; Napieralski M. 2017.

7 To encyklopedie, leksykony i przewodniki poświęcone zabytkowym budowlom warszawskim (np. Chrościcki J.A., Rottermund A. 1977, s. 96; Encyklopedia Warszawy. 1975, s. 388) i generalnie położonym na Mazowszu (np. Libicki P., Libicki M. 2009; Żabicki J. 2010) lub odnoszące się do przeszłości dzielnicy Bielany, na terenie której znajduje się opisywane założenie (Spacerownik. 2009; Zieliński J. 2016).

8 W Archiwum Głównym Akt Dawnych w Warszawie, Seria 11, Archiwum Skarbu Koronnego LVI, Inwentarze Starostw, jednostka nr 304, nr mikr. 2915, s. 67-71 (Aneks).

9 Thornische wöchentliche Nachrichten. 1765; Wiadomosci Warszawskie. 1765.

10 Wydane na łamach „Kuryera Niedzielnego”, z objaśnieniami F.M. Sobieszczańskiego, Zug S.B. 1898.

11 Schlichtegroll F. 1795, s. 43-44.

12 Najbardziej znane i wymieniane w większości uwzględnionych tu prac poświęconych Młocinom są: projekt pałacu i założenia pałacowo-parkowego J.F. Knöbla z ok. 1752 r.; Zygmunta Vogla z 1803 i 1811 r. Widok Młocin oraz Wiatrak w Młocinach; Aleksandra Majerskiego z 1818 r. Widok asterii w Młocinach i Widok dawnej altany w Młocinach; Stanisława Gepperta, Mappa Młocin z ostatniej ćwierci XVIII w. Dokumentacja Knöbla i Gepperta ostatnio została opublikowana w doskonałej jakości w: Putkowska J. 2016, s. 168, [ryc.] 108; s. 170, [ryc.] 109-110; s. 172-173, [ryc.] 111; s. 457, [ryc.] 289. Pozostałe, wzmiankowane przedstawienia reprodukowane najliczniej w: Sokołowska-Grzeszczyk 1962, s. 142-143, [ryc.] 12-13; s. 147, [ryc.] 15.

13 Zwłaszcza: Planta miasta Warszawy. 1777; Okolice Warszawy w diametrze piaciu mil. 1783; Plan von Warschau. ok. 1796; Environs de Varsovie [Młociny]. 1819; Plan okolic Warszawy. 1829; Mapa okolic Warszawy. 2 poł. XIX w.; Karta okrestnostej Varšavy. 1836-1860; Karta Varšavskogo Učastka. 1875; Sonderplan. 1915; Brytyjskie zdjęcie lotnicze. 1944. Były one rzadko wykorzystywane i przywoływane w badaniach nad tym tematem (trzy z nich wzmiankowane w: Sokołowska-Grzeszczyk K. 1962, s. 138, przyp. 20; inne np. w: Zieliński J. 2016, s. 162-176, ryciny nienumerowane).

14 Por. np. biogram w: Konopczyński W. 1937. 
Johanna Friedricha Knöbla ${ }^{15}$. Budynek o charakterze willowym, o uproszczonej formie, lecz jak wskazują przekazy źródłowe bogato wyposażony ${ }^{16}$, stanął na wiślanej skarpie w pobliżu zabudowań wsi Młociny, przez którą wiodła droga ku niemu ${ }^{17}$. Dopełnieniem był niewielki ogród założony przed frontem pałacu od strony Wisły, czyli od północy, regularny ogród i sad na wschód od budynku, a także park z układem duktów od południa ${ }^{18}$. Powstała tym samym podmiejska siedziba magnacka, która, zdaniem Jolanty Putkowskiej, pełniła raczej funkcję dworu myśliwskiego ${ }^{19}$. Kilkaset metrów od budynku pałacowego rozciągał się bowiem zwierzyniec - obszar ogrodzony, wydzielony z dużego kompleksu leśnego zwanego Puszczą Młocińską. Jako królewski leśny zwierzyniec istniał już zapewne przed budową brühlowskiego założenia $^{20}$. Został on połączony z nowym pałacem i folwarkiem aleją. Autorstwo jego aranżacji również przypisuje się Johannowi Friedrichowi Knöblowi ${ }^{21}$.

Po śmierci saskiego ministra dobra młocińskie odziedziczył jego starszy syn - Alojzy Fryderyk (1739-1793), starosta warszawski i generał artylerii koronnej22. Zdaniem badaczy to on do prac w Młocinach zatrudnił Szymona Bogumiła Zuga, architekta niemieckiego pochodzenia, do stworzenia założenia ogrodowego prawdopodobnie od lat sześćdziesiątych XVIII w. ${ }^{23}$ lub — według nowszych ustaleń — pomiędzy rokiem 1772 a przed $1784^{24}$. Zug zasłynął zwłaszcza projektami sentymentalnych zespołów ogrodowych z pawilonami w stylu „malowniczym”25. Także w tym przypadku jego zadaniem, poza przebudową samego pałacu było, jak można sądzić, przeorganizowanie kompozycji przestrzennej na skarpie wiślanej. Zapewne w efekcie tych działań powstał „piękny pałac z przepysznym [...] ogrodem” — jak opisał siedzibę młocińską, należącą do hrabiego Brühla, w swoim pamiętniku spisanym po roku 1840, Jan Duklan Ochocki ${ }^{26}$. Prawdopodobnie otoczenie zaaranżowano wtedy w stylu angielskim (,wiejskim”) ${ }^{27}$, a sam S.B. Zug w 1784 r. określił to miejsce jako „piękny dom wiejski, przy którym jest ładny sad i miejsce dziko zarosłe, schodzące aż do płaskiego brzegu Wisły"28.

Wycofując się z aktywnego życia, podjąwszy zamiar przeniesienia się do rodzinnej Saksonii, w roku 1790 Alojzy Fryderyk Brühl sprzedał młociński majątek Michałowi Starzeńskiemu, staroście brańskiemu, od którego z kolei jeszcze w latach dziewięćdziesiątych nabył go kupiec i bankier niemieckiego pochodzenia, Jerzy Fryderyk Poths (1750-1807) ${ }^{29}$. Młociny pozostawały w rękach rodziny Pothsów do początku XX w., przy czym sam pałac, pod nazwą „Willa pałacowa Młociny” o powierzchni „mórg ${ }^{2} 17$ prętów² 254”, odłączono od reszty majątku i sprzedano w 1876 r. ${ }^{30}$ Pozostała część dawnego założenia, obejmująca rozległy niegdyś

15 Sokołowska-Grzeszczyk K. 1962, s. 128; Sito J. 2016, s. 260-261.

16 Sokołowska-Grzeszczyk K. 1962, s. 127-131, ryc. 1.

17 To dzisiejsza ulica Prozy.

18 Sokołowska-Grzeszczyk K. 1962, s. 129-130.

19 Był to drugi taki obiekt należący do Henryka Brühla. Pierwszy, pełniący podobne funkcje, lecz bardziej okazały, powstał w tym czasie (po 1747 r.) w Piasecznie, Putkowska J. 2016, s. 169-171.

20 Sokołowska-Grzeszczyk K. 1962, s. 126.

21 Putkowska J. 2016, s. 174.

22 Por. np. Hniłko A. 1937, s. 13-16; Dudziak J. 2010.

${ }^{23}$ Kwiatkowski M. 1971, s. 83-85; Sokołowska-Grzeszczyk K. 1962, s. 130. Według E. Pustoły-Kozłowskiej (1991, s. 3) to J.Ch. Schuch współpracował z Zugiem jako planista ogrodu od 1779 r.

${ }^{24}$ Mączyński R. 2016, s. 500-501, 503.

25 Pevsner N. i in. 1992, s. 406.

26 Bukar S. 1912, s. 48.

${ }^{27}$ Kwiatkowski M. 1971, s. 86.

28 Zug S.B. 1898, s. 443.

29 Biogram J.F. Pothsa, por. Hass L. 1982, s. 718. Dzieci Jerzego Fryderyka zmarły w dzieciństwie, a jego majątek odziedziczył młodszy brat, Henryk Filip (1759-1834), protoplasta polskiej gałęzi Pothsów.

${ }^{30}$ Pustoła-Kozłowska E. 1991, s. 3; Pustoła-Kozłowska E. i in. 2005, s. 82. 
zwierzyniec oraz park, podlegała dalszym przekształceniom i parcelacji ${ }^{31}$. Następnymi właścicielami zespołu pałacowego wraz z najbliższym otoczeniem byli warszawscy bankierzy, Hipolit Wawelberg i Stanisław Rotwand. W latach 1896-1906 nieruchomość trzykrotnie zmieniała właścicieli, kolejnymi zaś (w latach ok. 1906-1939) była rodzina Grodzickich. Po śmierci nabywcy, Stefana Antoniego ( $† 1919)$, majątek odziedziczyły jego dzieci — Stefan Kazimierz, który przejął pałac z otaczającym go parkiem, oraz Irena z Grodzickich Żeglińska, która otrzymała sad z ogrodem warzywnym ${ }^{32}$. W latach trzydziestych teren sadów podzielono na działki i wyznaczono tam obecną ulicę Wygon, znacznie zmniejszając teren pałacowej posesji ${ }^{33}$. W maju 1934 r. wskutek pożaru uległa zniszczeniu część pałacu ${ }^{34}$.

W latach okupacji niemieckiej przez krótki czas jedną z oficyn pałacowych zajmowały zakonnice ze Zgromadzenia Sióstr Urszulanek. Po drugiej wojnie światowej pałac ocalał, a dobra te przejął Skarb Państwa. Następnie (u schyłku lat czterdziestych) budynek stał się siedzibą Muzeum Kultur Ludowych, późniejszego Muzeum Etnograficznego, z przestrzenią wystawową oraz magazynową. Muzeum funkcjonowało na Młocinach do lat sześćdziesiątych. Po 1971 r. obiekt miał się stać Domem Zasłużonego Twórcy Związku Literatów Polskich. W latach osiemdziesiątych należał on do Instytutu Matematyki PAN, potem zaś przeszedł w prywatne ręce ${ }^{35}$. Od lat dziewięćdziesiątych XX w. do dziś trwa zabudowa mieszkaniowa pozostałych obszarów dawnego parku, w tym przedwojennych sadów na wschód od pałacu i na prawo od alei wjazdowej, wzdłuż współczesnego, wschodniego ogrodzenia ${ }^{36}$, zniknął też ogród na południe od pałacu. Od 1 lutego 2008 r. właścicielem obiektu, dzisiejszej posesji przy ulicy Muzealnej 1, jest Sylwester Gardocki ${ }^{37}$. Obecnie nie są tu prowadzone żadne prace remontowo-budowlane, a założenie nie jest dostępne.

W skład osiemnastowiecznego założenia w Młocinach, oprócz głównego korpusu pałacu wchodziły obiekty usytuowane zarówno w jego najbliższym sąsiedztwie, jak i w oddaleniu od niego, w obrębie ogrodu pałacowego oraz poza nim. Powstały one w efekcie realizacji ówczesnej kompleksowej koncepcji architektonicznej. To „,budowle [...] niezbędne w każdego rodzaju ogrodzie, [które — M.B., W.B., M.N.] pomagają urozmaicić krajobraz, dają przyjemność oku, zajęcie umysłowi, służą za schronienie i są nawet użyteczne”, jak pisał w swojej Rozprawie o ogrodnictwie angielskim z 1774 r. August Fryderyk Moszyński ${ }^{38}$. W przypadku analizowanego założenia funkcjonowały one wraz z pałacem, lecz w większości dość krótko (maksy-

31 W 1837 r. część majątku przeznaczono na tereny wojskowe. W 1864 r. przekazano na własność chłopom uprawiane przez nich pola (Korotyński W. 1918, s. 224; Pape D. 2008, s. 3). Natomiast w części północnej dawnego zwierzyńca powstał folwark z zabudowaniami i lasem, których zasięg stopniowo malał (w 1867 r. zajmował ok. 100 włók, Korotyński W. 1918, s. 224), co obrazują np. mapy wydane po 1845 (Plan okrestnostej goroda Varšavy. po 1845) i w 1860 r. (Karta okrestnostej Varšavy. 1836-1860). W 1907 r. znaczną część parku i las pomiędzy Wisłą a szosą do Zakroczymia (o powierzchni 226 mórg i 118 prętów) rodzina Pothsów sprzedała Magistratowi Warszawy. W 1911 r. na tym terenie założono park nazwany Laskiem Młocińskim, według projektu Stanisława Rutkowskiego (Pape D. 2008, s. 3). W 1914 r. w obrębie dawnego zwierzyńca planowano założenie dzielnicy willowej - „Miasta-Ogrodu Młociny”, według projektu Ignacego Miśkiewicza. Jej realizację przerwał wybuch I wojny światowej (Pape D. 2008, s. 3-4; Zieliński J. 2016, s. 216-217). Znaczna degradacja tego obszaru nastąpiła w czasach PRL. Spory obszar dawnego zwierzyńca zajęła budowana w latach pięćdziesiątych XX w. Huta Warszawa oraz powstała w kolejnej dekadzie zajezdnia tramwajowa „Żoliborz”, z czasem rozwijająca się też stopniowo zabudowa mieszkaniowa. Przekształcenia te obrazują zdjęcia lotnicze z lat siedemdziesiątych i osiemdziesiątych (Muzealna. 1976-1977; Muzealna. 1982; Muzealna. 1987).

32 Pape D. 2008, s. 4; Spacerownik. 2009, s. 20.

33 Pustoła-Kozłowska E. 1991, s. 4; Pape D. 2008, s. 4-5.

34 Olbrzymi pożar. 1934.

35 Pape D. 2008, s. 18; Spacerownik. 2009, s. 20.

36 Zgodę na tę inwestycję wydał ówczesny Konserwator Zabytków, mimo iż granice ochrony konserwatorskiej były wyznaczone i obejmowały całe założenie pałacowo-parkowe, Pape D. 2008, s. 5.

37 Bis M., Bis W. 2011-2012, s. 92.

38 Morawińska A. 1977, s. 94. 


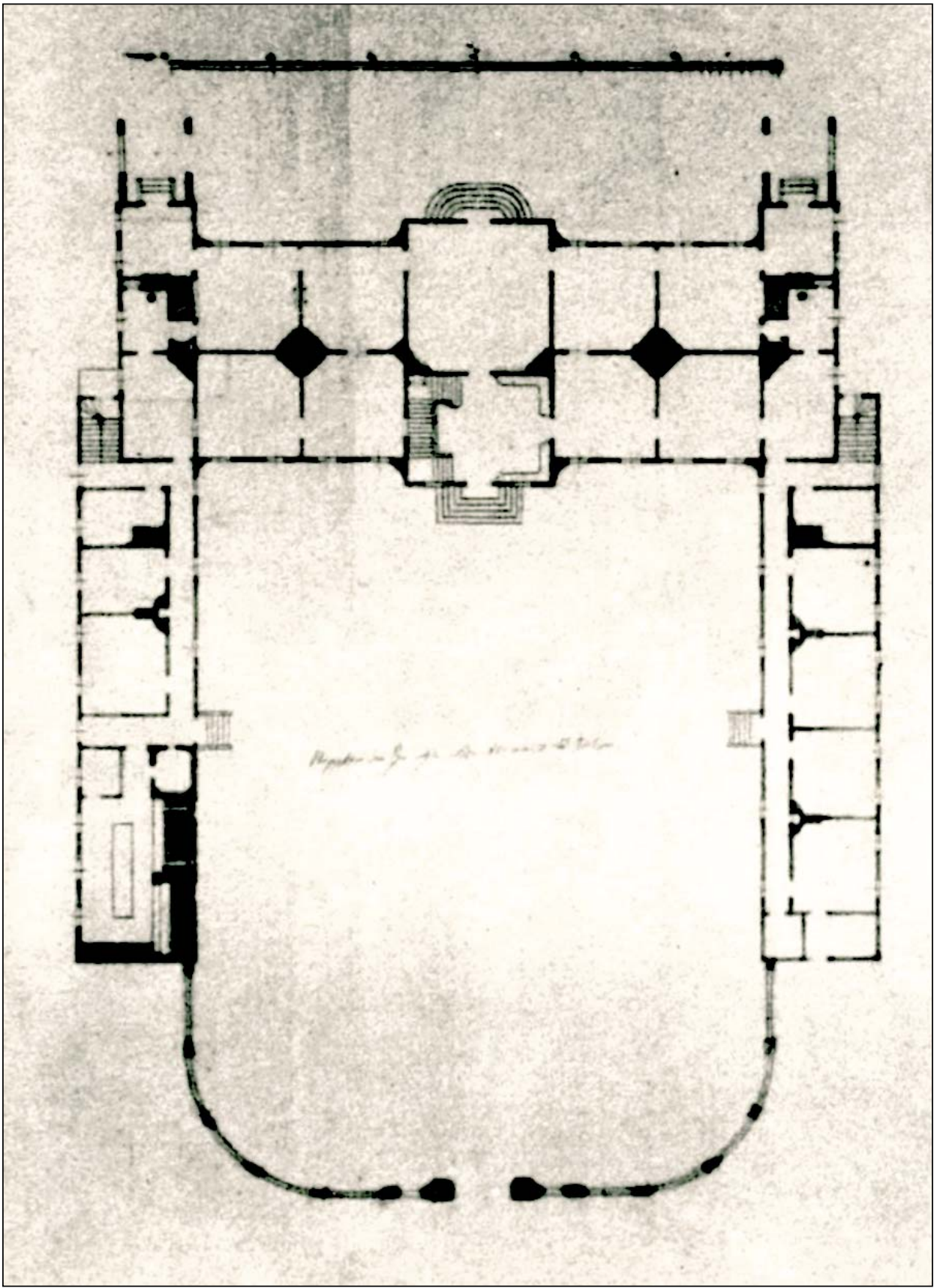

Ryc. 2. Pierwszy projekt pałacu S.B. Zuga, rzut parteru z oficynami i palisadą-pergolą, niedatowany, za: Hentschel W. 1967, t. II, [ryc.] 455

Fig. 2. The first design of the palace of S.B. Zug, a projection of the ground floor with outhouses and palisades, undated, after: Hentschel W. 1967, vol. II, [Fig.] 455 
malnie kilkadziesiąt lat) w porównaniu z główną budowlą, która przetrwała ok. 270 lat do dziś. Ich istnienie poświadczają rozmaite źródła.

O f i c y n y — odnośnie do tych budynków dysponujemy największą liczbą danych. Powstały w XVIII w., prawdopodobnie niedługo po budowie samego pałacu, stanowiąc efekt jednej inwestycji. Na najstarszym znanym przekazie ikonograficznym dotyczącym młocińskiej siedziby — rysunku z ok. 1752 r., którego autorstwo przypisuje się J.F. Knöblowi, oficyn brak $^{39}$. Widnieją one na dokumentacji pochodzącej z ok. $1760^{40}$ lub z $1786 \mathrm{r}^{41}$ sporządzonej przez S.B. Zuga. To dwa budynki boczne, wydłużone i parterowe, różniące się podziałem wewnętrznym, ulokowane w bezpośrednim sąsiedztwie pałacu, od południa ${ }^{42}$ (ryc. 2). Niezależnie od tego, czy dokumentacja ta stanowi inwentaryzację stanu budowli, czy też tylko jej wyobrażenie ${ }^{43}$, oficyny w przybliżonym czasie rzeczywiście powstały i to łącznie trzy. Potwierdza to bowiem relacja z 1765 r. — „Inwentarz wsi Młocin w województwie mazowieckim ziemi warszawskiej leżący" "44. Zbudowano je zatem przed tymże rokiem, w latach pięćdziesiątych lub na początku sześćdziesiątych XVIII stulecia, gdy dobra te były jeszcze własnością Henryka Brühla (†1763), albo wkrótce po jego śmierci, gdy były już w posiadaniu jego syna, Alojzego Fryderyka (nadaniem z $1764 \mathrm{r}^{45}$ ). Oficyny znajdowały się w obrębie założenia, za bramą, a łączyła je konstrukcja zwaną palisadą ${ }^{46}$, czyli zapewne dekoracyjna pergola. W dokumencie opisano je analogicznie: „na fundamencie murowanym $\mathrm{z}$ drzewa tartego postawione”, z dachem ,gontami czerwono malowanymi pobite”. Jak wynika z rejestru, wewnątrz dwóch z nich była sień, cztery pokoje i „sala”, w trzeciej zaś — sień oraz „po obu stronach izbów cztery" ${ }^{\prime 7}$. Dostrzegalne jest pewne zróżnicowanie w standardzie ich nieruchomego wyposażenia. I tak, w oficynach z pokojami i salą był on nieco wyższy w porównaniu z oficyną trzecią, co przejawiało się niektórymi detalami: sufity dekorowane były płótnem (albo odpowiednio: z tarcic mocowanych ,na zakładkę”), podłogi wyłożono heblowanymi tarcicami (albo zwykłymi tarcicami), w jednym z pokoi, w jego narożniku stał kominek murowany kapiasty (albo urządzenia tego nie było). Poza tym, o ile można wnioskować na podstawie owego opisu, podobnymi elementami były okna z szybami oprawionymi w dębowe ramy $\mathrm{i}, \mathrm{w}$ ołów", podzielone przeważnie na cztery kwatery i zaopatrzone w zewnętrzne okiennice, oraz drzwi drewniane, z reguły „fasowane”. Odrębny budynek zajmowała kuchnia; wchodziło się do niej z boku, od strony ogrodu, a jej wnętrze mieściło jedną izdebkę, która miała odmiennie wykonany sufit - gipsowy i posadzkę ceglaną, oraz piekarnię, sionkę i piwnicę. W tej ostatniej, do której prowadziły schody dębowe, wydzielono trzy komórki. Chociaż jedynie w odniesieniu do piwnicy stwierdzono, że jest ,z gruntu murowana, na której dach karpiówką

39 Publikowane w: Sokołowska-Grzeszczyk K. 1962, s. 137, [ryc.] 9, oryginał w Muzeum Narodowym w Warszawie (NB 3573); Putkowska J. 2016, s. 168, [ryc.] 108, oryginał w Sächsisches Staatsarchiv Hauptstaatsarchiv Dresden. Obie wersje planu różnią się od siebie zwłaszcza kompozycją głównej alei, a zamieszczone zostały też w: Hentschel W. 1967, t. II, [ryc.] 453 i [ryc.] 454.

40 Kwiatkowski M. 1971, s. 24, [ryc.] 11 i s. 26.

${ }^{41}$ Katalog rysunków. 1967, s. 193.

42 Kozłowska B. 2005, s. 8. Taką wersję prezentuje rysunek, dotychczas niepublikowany w polskich pracach, Hentschel W. 1967, t. II, [ryc.] 455.

${ }^{43}$ Za pierwszą koncepcją opowiadała się K. Sokołowska-Grzeszczyk (1962, s. 132), natomiast M. Kwiatkowski (1971, s. 24, [ryc.] 11 i s. 26) uważał ten rysunek za niezrealizowany projekt.

44 Por. Inwentarz. 1765. Dokument ten włączono do niniejszego artykułu jako Aneks.

45 Alojzy Fryderyk jako „Wielmożny Brühl” był „posesorem dzierżawy Młociny [...] podług konsensusu Stanisława Augusta z dnia 31.XII.1764 r.”, Pustoła-Kozłowska E. 1991, s. 2 i przyp. 3; por. też Korotyński W. 1918, s. 222-223.

${ }^{46}$ Termin użyty w odniesieniu do tej konstrukcji w inwentarzu z 1765 r. (Inwentarz. 1765, s. 68; Aneks). W dalszej części artykułu zamieszczono wyjaśnienie jej budowy i przeznaczenia.

47 Inwentarz. 1765, s. 67-68; Aneks. 


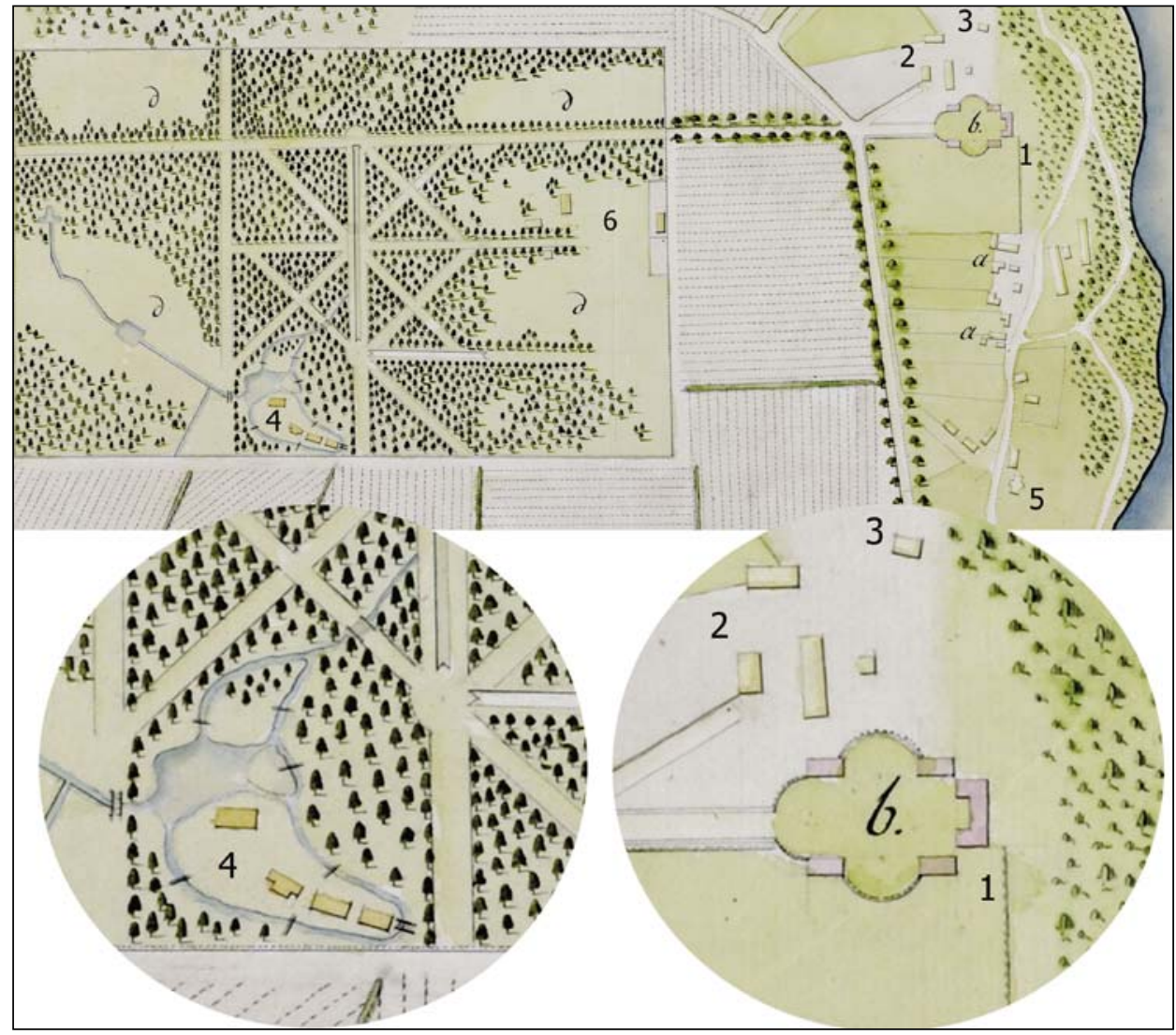

Ryc. 3. Założenie pałacowo-ogrodowe w Młocinach według: Mappa Młocin S. Gepperta z ostatniej ćwierci XVIII w., fragment: a — zabudowania wsi Młociny; b — pałac;

d - zwierzyniec; 1 - pałac z czterema oficynami, palisadami i przejazdem; 2 - folwark; 3 - cegielnia(?); 4 - zabudowania na wyspie w zwierzyńcu; 5 - karczma (austeria); 6 - inne budynki na terenie zwierzyńca (za: Mappa Młocin. 4 ćw. XVIII w., ze zbiorów Gabinetu Rycin Uniwersytetu Warszawskiego; oprac. W. Bis)

Fig. 3. The palace and garden in Młociny on S. Geppert's map of Młociny from the 4th quarter of the 18th c., a fragment: a - the village of Młociny; $b$ - the palace; $d$ - the game park; 1 - the palace with four outhouses, palisades and the passage; 2 - the home farm; 3 - the brickyard(?); 4 - buildings on an island in the game park; 5 - the inn; 6 - other buildings in the game park (after: Mappa Młocin. 4th quarter of the 18th c., in the Collection of Prints of the University of Warsaw; compiled by W. Bis)

pobity", ale sformułowanie to zdaje się tyczyć konstrukcji całego tego budynku. Byłaby ona analogiczna do głównego gmachu, który wedle tego wykazu był również „,z gruntu murowany [...] dachówką karpiówką pokryty"48.

Oficyny flankujące dziedziniec już w liczbie czterech przedstawione zostały na Mappie Młocin, czyli na planie Stanisława Gepperta z ostatniej ćwierci XVIII w. (ryc. 3:b, 1). Mają tu one podobny prostokątny kształt i rozmiary, usytuowane są symetrycznie — po dwie

${ }^{48}$ Inwentarz. 1765, s. 70; Aneks. 


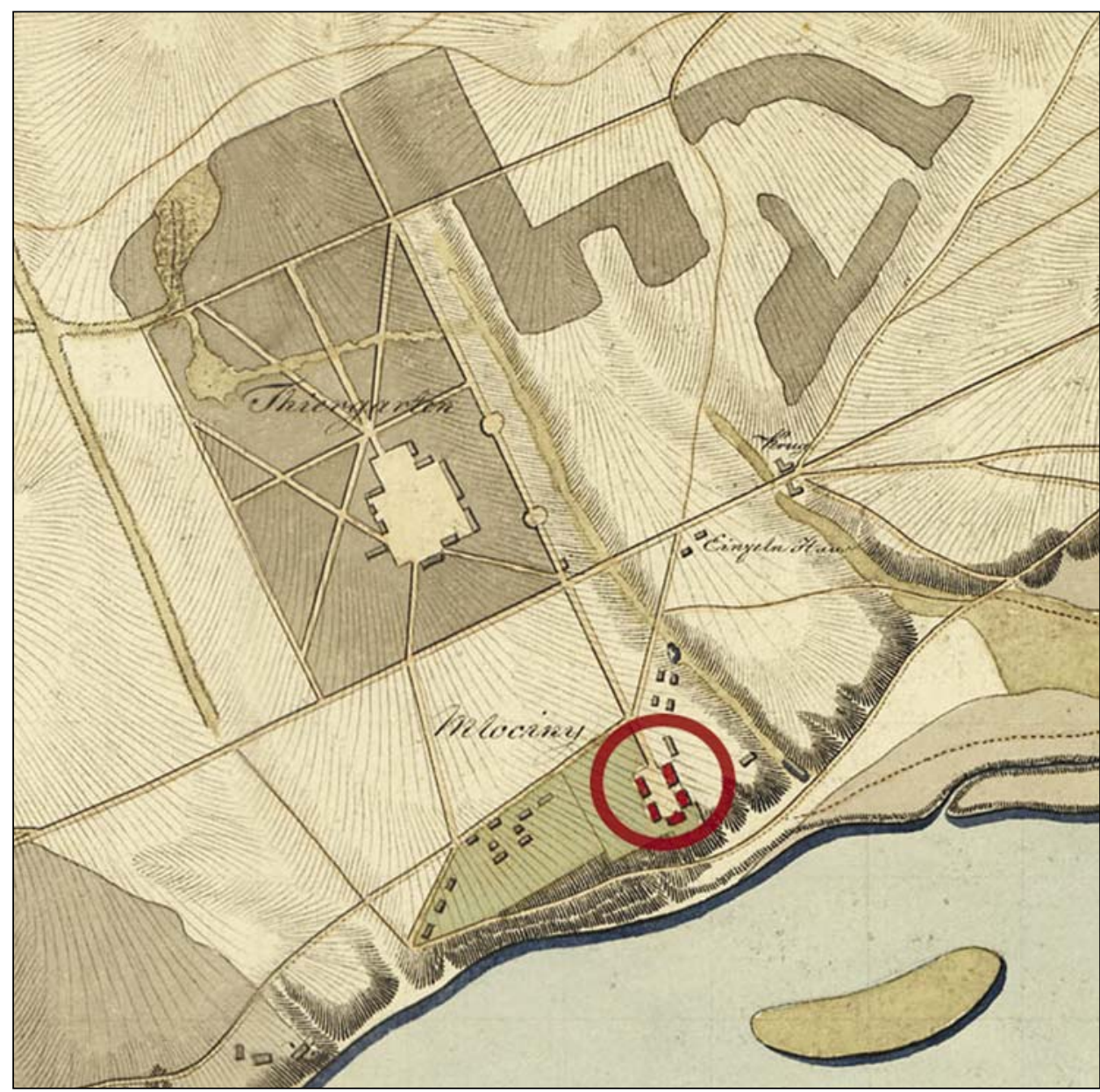

Ryc. 4. Założenie pałacowo-ogrodowe w Młocinach według: Plan von Warschau und Prag nebst umliegender Gegend z ok. 1796 r., fragment (za: Plan von Warschau und Prag. ok. 1796; oprac. W. Bis); czerwonym kolorem oznaczono lokalizację pałacu z najbliższymi zabudowaniami

Fig. 4. The palace and garden in Młociny after: Plan von Warschau und Prag nebst umliegender Gegend, c. 1796, a fragment (after: Plan von Warschau und Prag. c. 1796; compiled by W. Bis); the red colour marks the palace and its precincts

w dwóch rzędach, naprzeciwko siebie, a zarazem prostopadle do pałacu, krótszymi bokami ku północy. Ze sobą oraz z bramą połączone są czterema łukowato przebiegającymi kolumnadami. Na podstawie tego schematycznego planu trudno rozstrzygnąć, z jakiego wzniesiono je budulca ${ }^{49}$. Przyjmując, że S. Geppert zaprezentował rzeczywisty stan ówczesnej posesji, to rozbudowę założenia zakładającą powstanie większej liczby oficyn zrealizowano najpewniej niedługo po sporządzeniu wspomnianego powyżej spisu, a najpóźniej przed rokiem 1790, czyli datą sprzedaży nieruchomości przez A.F. Brühla. Prawdopodobnie dokonano tego w czasie prac prowadzonych tu pod kierunkiem S.B. Zuga. Jednym z przejawów urzeczy-

${ }^{49}$ Zdaniem B. Kozłowskiej rysunek ten prezentuje oficyny murowane, Kozłowska B. 2005, s. 8. 


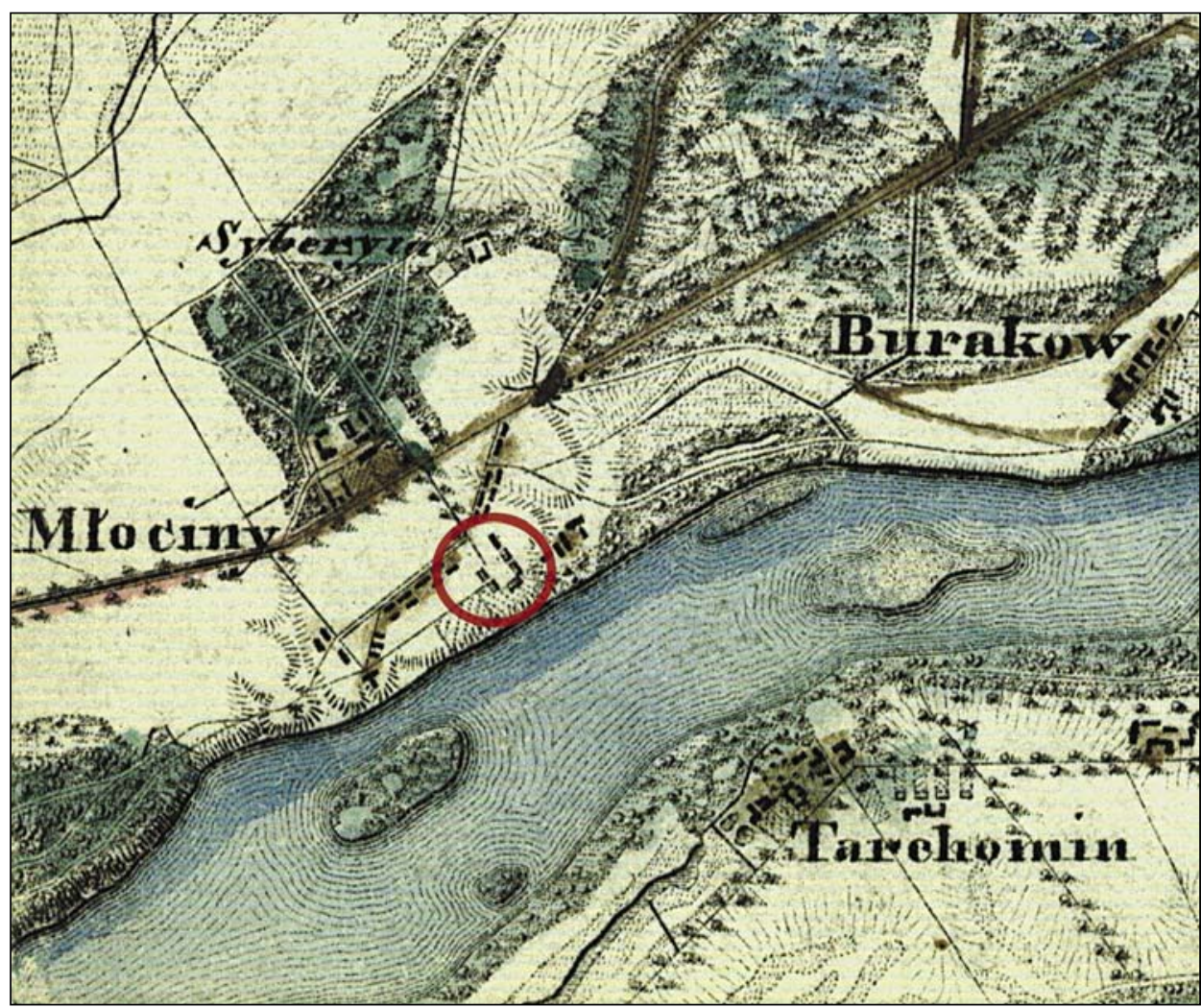

Ryc. 5. Założenie pałacowo-ogrodowe w Młocinach według: Plan okolic Warszawy. Plan des environs de Varsovie z 1829 r., fragment (za: Plan okolic Warszawy. 1829; oprac. W. Bis); czerwonym kolorem oznaczono lokalizację pałacu z najbliższymi zabudowaniami

Fig. 5. The palace and garden in Młociny after: Plan okolic Warszawy. Plan des environs de Varsovie from 1829, a fragment (after: Plan okolic Warszawy. 1829; compiled by W. Bis); the red colour marks the palace and its precincts

wistnienia zamysłów architekta, tj. modernizacji młocińskiego założenia, było zapewne nie tylko postawienie czwartej oficyny, ale także przebudowa pozostałych — drewnianych na murowane ${ }^{50}$. Podjęcie takich inwestycji wydaje się prawdopodobne w związku ze zmianą charakteru siedziby, która z miejsca czasowego pobytu, jaką była za Henryka Brühla, miała się stać rezydencją Alojzego Fryderyka ${ }^{51}$, spełniającą zapewne odpowiednie wymogi w zakresie reprezentacji, komfortu i funkcjonalności. W trzech oficynach mieściły się, jak można sądzić, rozmaite pomieszczenia dla gości i służby oraz o przeznaczeniu gospodarczym. W ostatniej ulokowana była kuchnia z piekarnią; tu też znajdowała się piwnica ${ }^{52}$, zapewne o funkcji magazynowej.

${ }^{50}$ Por. Pustoła-Kozłowska E. 1991, s. 8. Do czasów współczesnych w takiej konstrukcji przetrwały oficyny znajdujące się tuż przy pałacu, zwane przez nas pierwszymi; ustalenia na podstawie oglądu konstrukcji obu budynków dokonanego przez M. i W. Bis w 2010 r.

${ }^{51}$ Por. Korotyński W. 1918, s. 223; Hniłko A. 1937, s. 13; Pape D. 2008, s. 11; Spacerownik. 2009, s. 20.

52 Na podstawie: Inwentarz. 1765. Podczas inspekcji lokalnej przeprowadzonej przez M. i W. Bis w $2010 \mathrm{r}$. stwierdzono, że piwnica istniała pod obecną oficyną pierwszą prawą. 


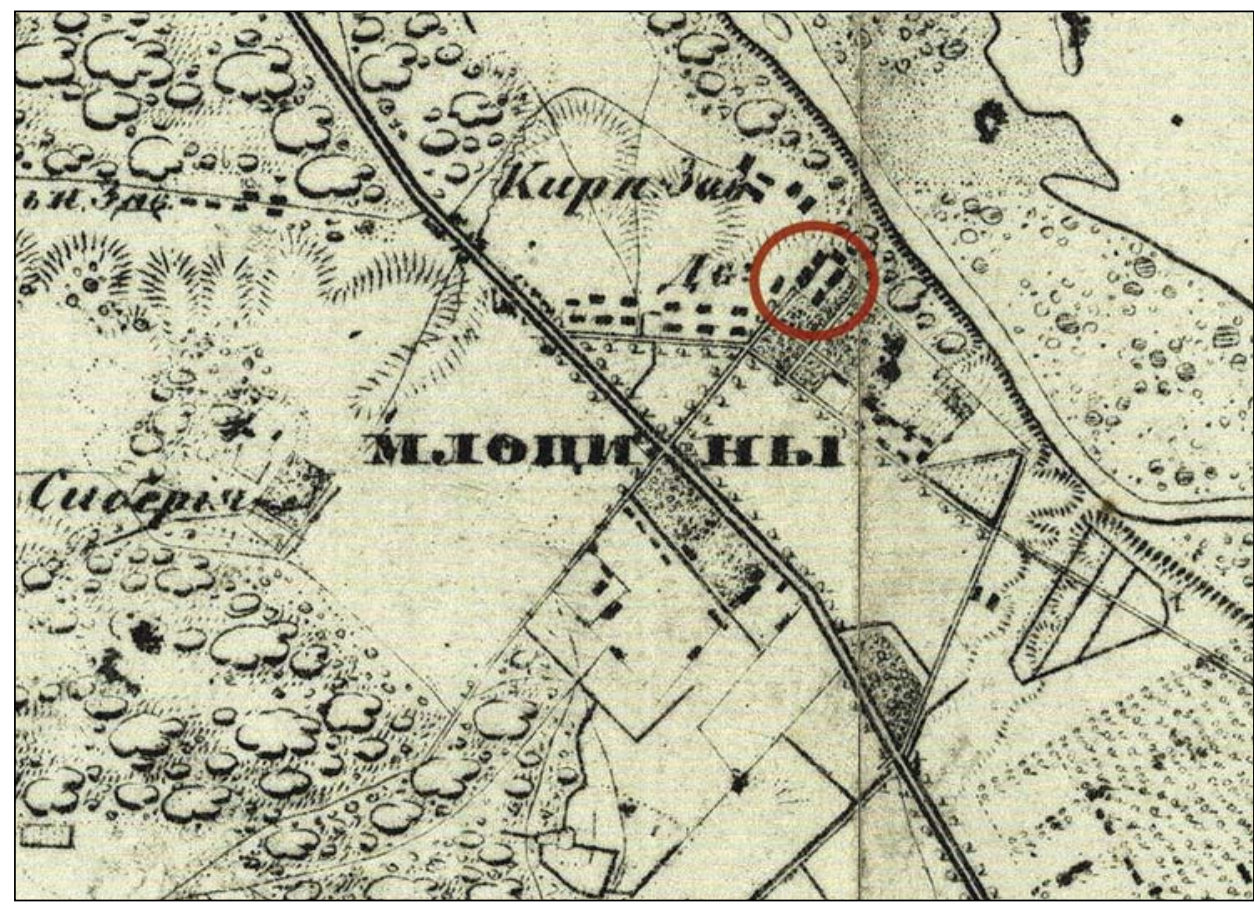

Ryc. 6. Założenie pałacowo-ogrodowe w Młocinach według: Plan okrestnostej goroda Varšavy po 1845 r., fragment (za: Plan okrestnostej goroda Varšavy. po 1845; oprac. W. Bis); czerwonym kolorem oznaczono lokalizację pałacu z najbliższymi zabudowaniami

Fig. 6. The palace and garden in Młociny after: Plan okrestnostej goroda Varšavy from after 1845, a fragment (after: Plan okrestnostej goroda Varšavy. after 1845; compiled by W. Bis); the red colour marks the palace and its precincts

Z kolei na Plancie miasta Warszawy z okolicami datowanej na 1777 r. narysowano tylko dwa takie budynki ${ }^{53}$. Jednak zabudowania młocińskie, a także sąsiedni zwierzyniec zaznaczono tu niedokładnie i w sposób uproszczony. Mapa ta zapewne stanowi pierworys dla innego dzieła kartograficznego ${ }^{54}$. Można zatem przyjąć, że także w odniesieniu do omawianego założenia zawiera jedynie próbę zasygnalizowania jego geometrycznego rozplanowania, natomiast nie należy jej traktować jako dokładną dokumentację. W związku z tym nie przesądza też o nieobecności wtedy dalszych dwóch przypałacowych oficyn. Z podobnych względów dla niniejszych rozważań ograniczona jest także przydatność mapy Okolica Warszawy w diametrze piaciu mil $\mathrm{z} 1783 \mathrm{r}^{55}$

O dalszym funkcjonowaniu wszystkich czterech oficyn zarówno u schyłku XVIII w., jak i w pierwszej połowie XIX stulecia świadczy np. pięć planów prezentujących tereny położone w rejonie Warszawy, w tym także Młociny. Opisywane budynki przedstawiono na nich w sposób zbliżony jak na Mappie Młocin. I tak, np. na trzech z nich: Plan von Warschau und Prag nebst umliegender Gegend z ok. 1796 r. ${ }^{56}$ (ryc. 4), na Planie Okolic Warszawy. Plan des Environs

${ }^{53}$ Planta miasta Warszawy. 1777.

54 Jankiewicz A. i in. 1999, s. 36.

55 Jankiewicz A. i in. 1999, s. 44-45.

56 Weszpiński P. 2007, s. 58. 


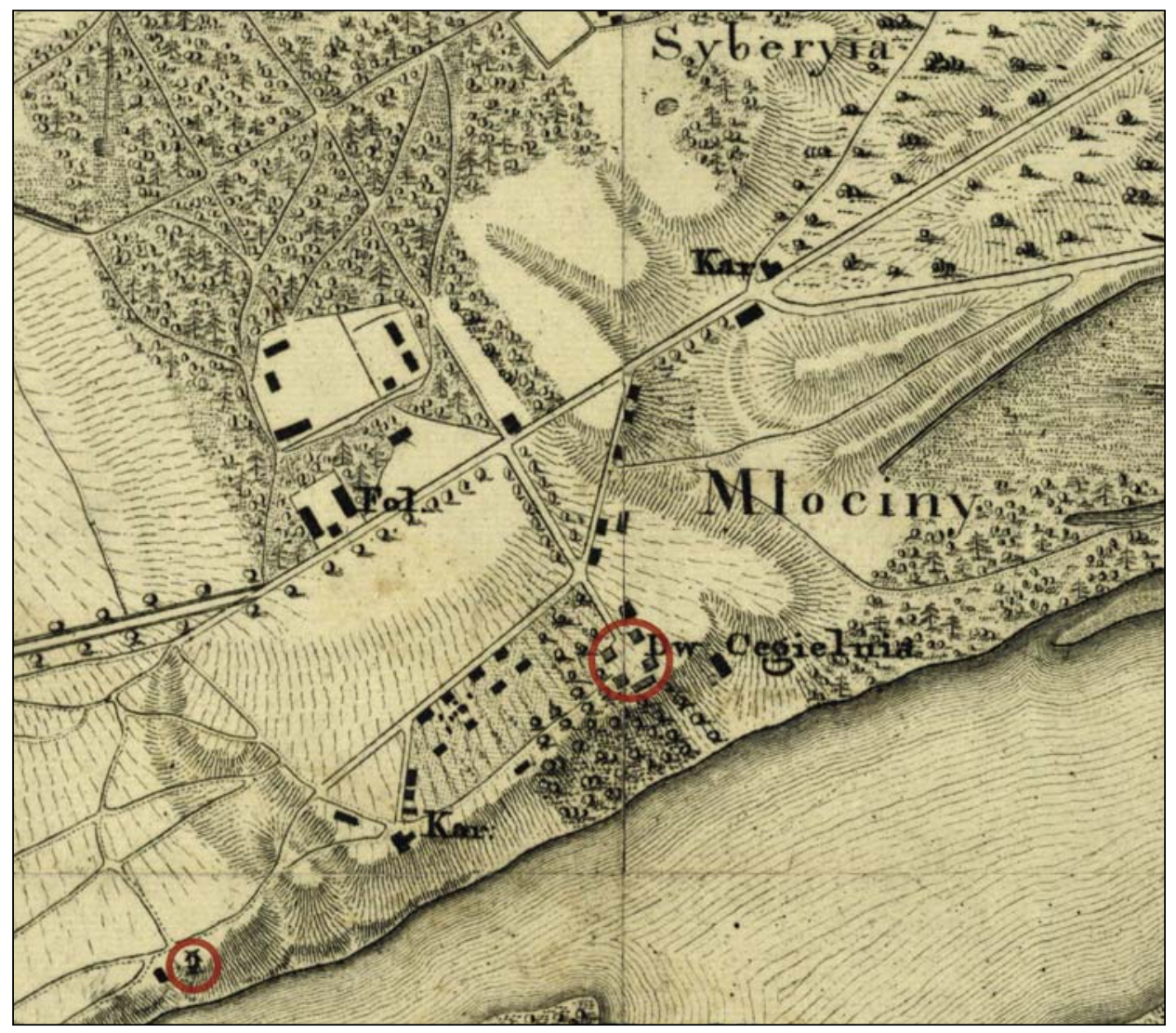

Ryc. 7. Założenie pałacowo-ogrodowe w Młocinach według: Environs de Varsovie [Młociny] z 1819 r. (wyd. 1820 r.), fragment (za: Environs de Varsovie [Młociny]. 1819; oprac. W. Bis); czerwonym kolorem oznaczono lokalizację pałacu z najbliższymi zabudowaniami i wiatraka

Fig. 7. The palace and garden in Młociny after: Environs de Varsovie [Młociny] from 1819 (published 1820), a fragment (after: Environs de Varsovie [Młociny]. 1819; compiled by W. Bis); the red colour marks the palace, its precincts and the windmill

des Varsovie z 1829 r. ${ }^{57}$ (ryc. 5) i Planie okrestnostej goroda Varšavy sporządzonym dla amii carskiej po 1845 r. $^{58}$ (ryc. 6) zobrazowano wyraźnie, choć w sposób uproszczony, istnienie w pobliżu siebie pięciu prostokątnych budynków. To pałac położony najbliższej wiślanej skarpy, prostopadle do czterech pozostałych i nieco większy od nich oraz zapewne cztery oficyny usytuowane równolegle do siebie, w dwóch rzędach (parami, w małych odstępach), o analogicznej wielkości. W linii oficyn lewych (na południowy zachód od pałacu), za drugą z nich widnieje kolejny podłużny kształt, wskazujący na funkcjonowanie tu w niewielkiej odległości jeszcze jednego budynku, zapewne gospodarczego. Bardziej uproszczoną wersję takiego rozplanowania analizowanych obiektów prezentuje również plan wykonany przez służby topograficzne Kwatermistrzostwa Generalnego w 1819 r. ${ }^{59}$ (ryc. 7). Cztery oficyny, lecz

57 Plan okolic Warszawy. 1829.

58 Plan okrestnostej goroda Varšavy. po 1845.

59 Environs de Varsovie [Młociny]. 1819. 


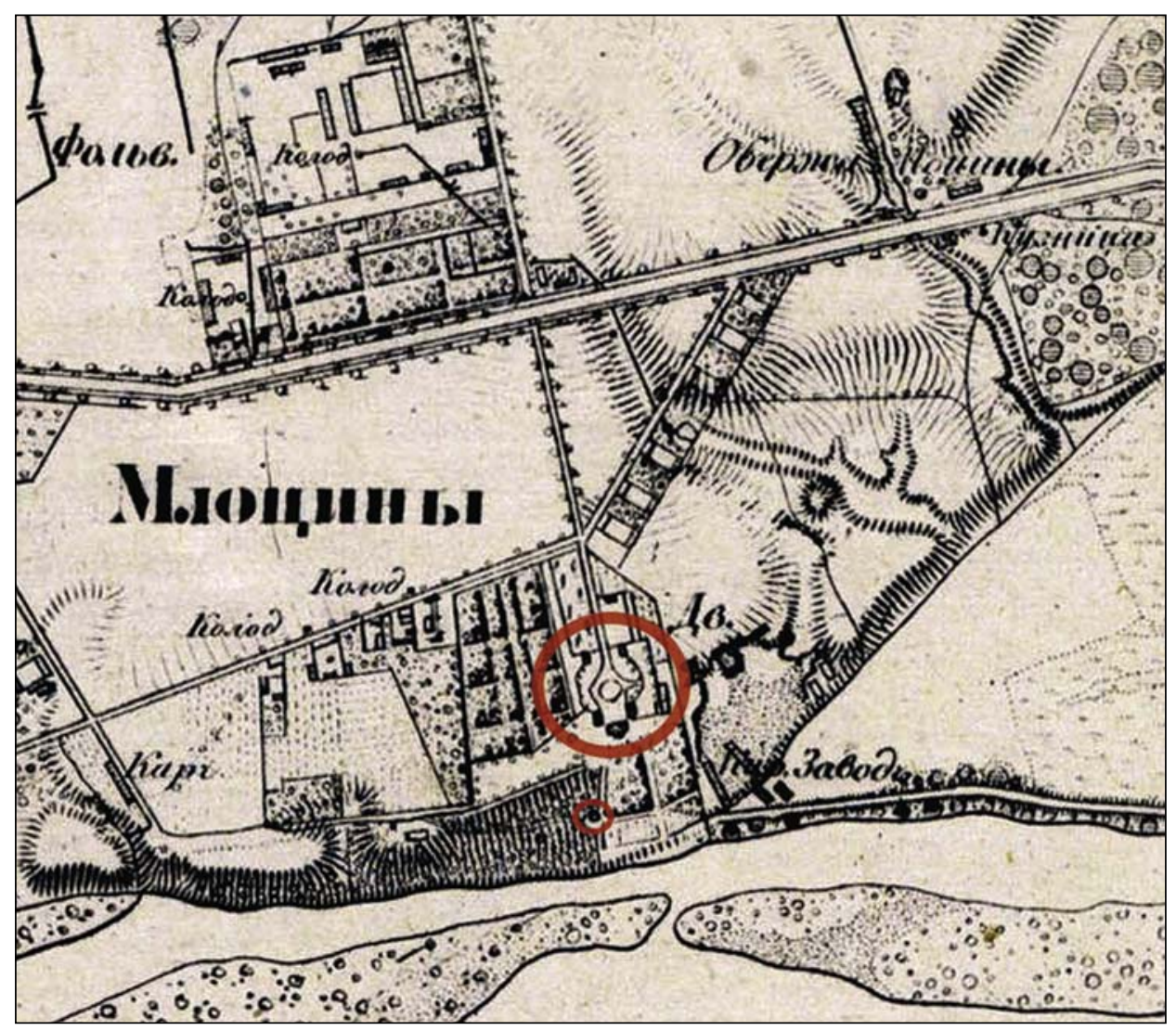

Ryc. 8. Założenie pałacowo-ogrodowe w Młocinach według: Karta okrestnostej Varšavy sniata instrumentalno $v$ 1836, ispravliena głazomierno w 1860 godu z 1836 r. (wyd. 1860 r.), fragment

(za: Karta okrestnostej Varšavy. 1836-1860; oprac. W. Bis); czerwonym kolorem oznaczono lokalizację pałacu z najbliższymi zabudowaniami oraz monopteru

Fig. 8. The palace and garden in Młociny after: Karta okrestnostej Varšavy sniata instrumentalno $v$ 1836, ispravliena głazomierno w 1860 godu from 1836 (published 1860), a fragment

(after: Karta okrestnostej Varšavy. 1836-1860; oprac. W. Bis); the red colour marks the palace with its precincts and the monopteros

o zróżnicowanych rozmiarach, rozmieszczone parami prostopadle do głównej siedziby wraz z łukowatymi kolumnadami pomiędzy dwiema z nich, przedstawiono z kolei na planie z $1836 \mathrm{r}$. sporządzonym przez oficerów Sztabu Generalnego Armii Rosyjskiej - Karta okrestnostej Varšavy ${ }^{60}$ (ryc. 8).

Użyteczność innych dziewiętnastowiecznych źródeł kartograficznych uwzględniających Młociny jest niestety niewielka. W rejonie analizowanej siedziby oznaczano jakieś budynki, lecz mało precyzyjnie, punktowo ${ }^{61}$. Tym samym poświadczają one tylko istnienie tu wówczas jakieś zabudowy, ale bliżej niezidentyfikowanej, której ani przeznaczenia, ani relacji względem siebie, wielkości bądź użytego budulca nie można na tej podstawie ustalić.

${ }^{60}$ Karta okrestnostej Varšavy. 1836-1860.

61 Np. Pape D. 2008, plany 5, 8. 


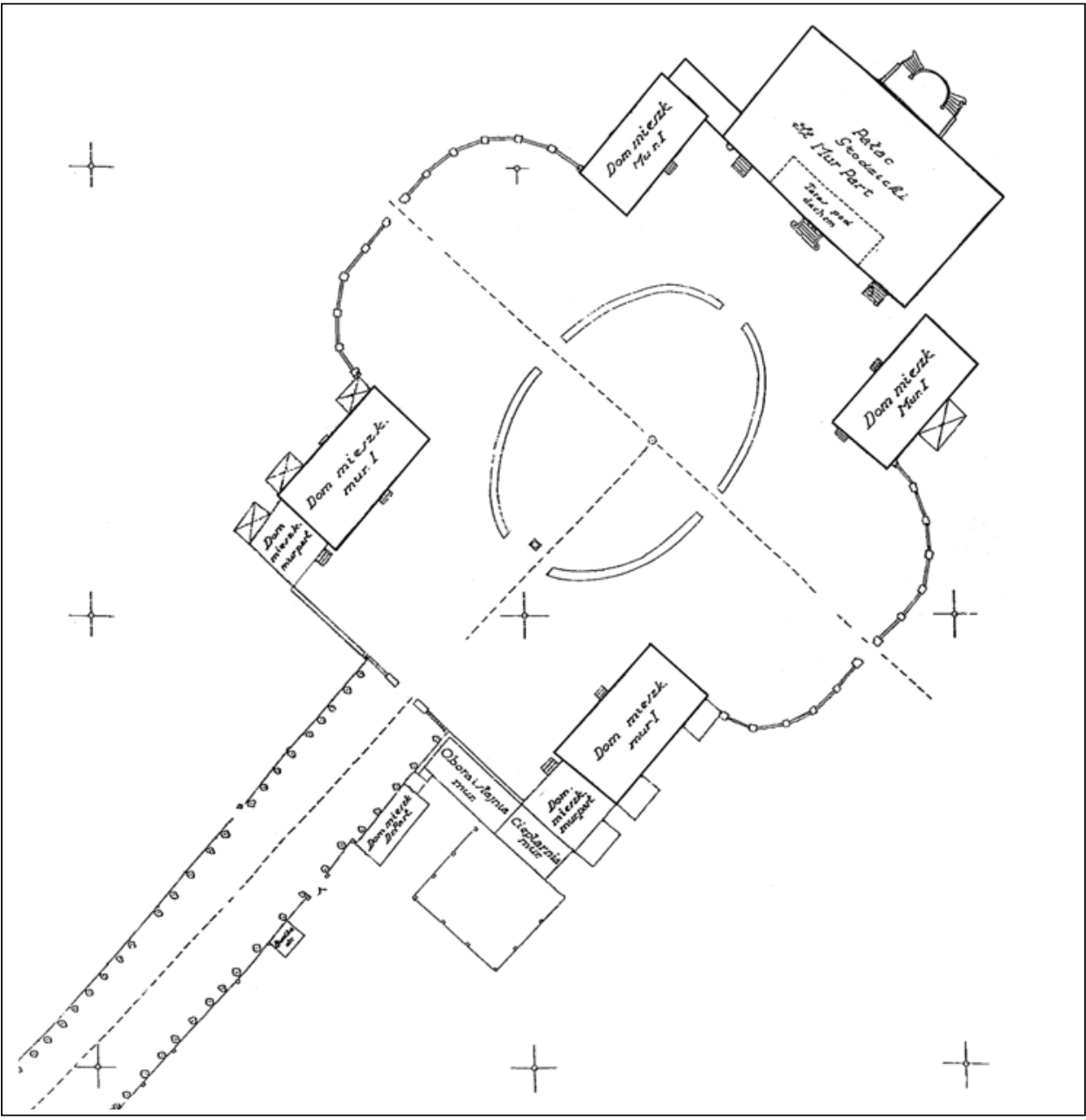

Ryc. 9. Projekt założenia pałacowo-ogrodowego w Młocinach dla Stefana Grodzickiego, niedatowany, fragment (rys. nieznany, z archiwum prywatnego S. Gardockiego; oprac. W. Bis)

Fig. 9. The design of the palace-and-garden complex in Młociny prepared for Stefan Grodzicki, undated, a fragment (author unknown, from the private archive of S. Gardocki; compiled by W. Bis)

Przyjmuje się, że pod koniec XIX w. dokonano gruntownej przebudowy zarówno pałacu, nadając mu tzw. kostium francuski ${ }^{62}$, jak i istniejących wtedy oficyn. Do tych ostatnich, parterowych dotąd budynków, dobudowano kolejną kondygnację oraz zmieniono pokrycie dachów — z dachówki na szarą łuskę z blachy cynkowanej ${ }^{63}$. Równocześnie uporządkowano też sąsiedni

${ }^{62}$ Termin ten oznacza $\mathrm{w}$ architekturze przeważnie recepcję form $\mathrm{z}$ renesansu francuskiego, jego manierystycznych mutacji oraz wczesnego baroku, reprezentowanego przez styl Ludwika XIII, przy zastosowaniu charakterystycznego dla tego stylu wątku ceglano-kamiennego oraz dachów mansardowych łamanych, Tołłoczko Z. 2016, s. 106.

${ }^{63}$ Sokołowska-Grzeszczyk K. 1962, s. 132-133. Natomiast zdaniem Danuty Pape (2008, s. 16) inwestycja ta miała większy zakres, tzn. polegała na likwidacji starych oficyn drewnianych, a budowie nowych, murowanych. Te stwierdzenia nie zostały jednak przez Autorkę uzasadnione. 


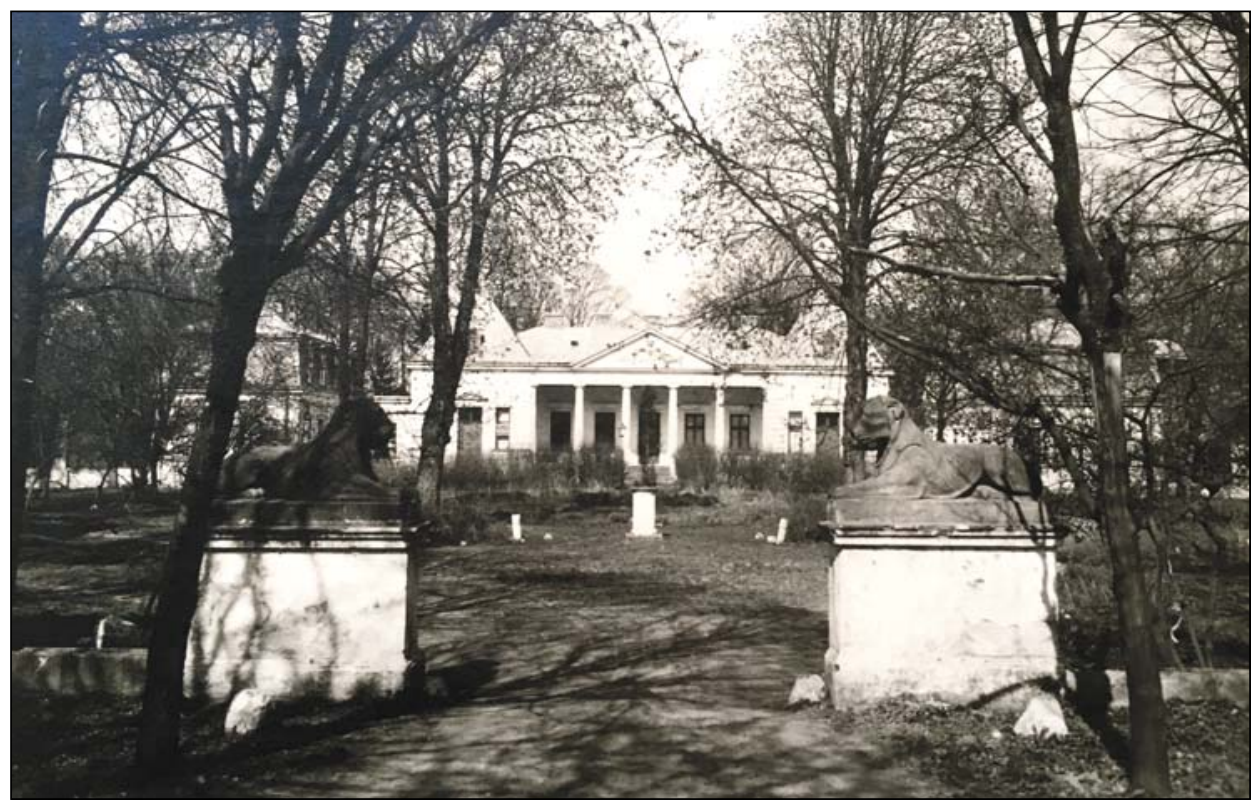

Ryc. 10. Założenie pałacowo-ogrodowe w Młocinach, widok od południa, przed przejazdem na dziedziniec, fotografia z 1916 r. (fot. H. Poddębski, ze zbiorów Instytutu Sztuki PAN, Warszawa, nr neg. 23556)

Fig. 10. The palace and garden in Młociny, a view from the south, in front of the passage to the courtyard, a photograph from 1916 (by H. Poddębski, from the Archives of the Art Institute of the Polish Academy of Sciences)

park. Nie wiadomo, czyją koncepcję architektoniczną wówczas zrealizowano oraz kiedy dokładnie. Według E. Pustoły-Kozłowskiej prace te przeprowadzono w $1898 \mathrm{r}^{64}$ albo pomiędzy rokiem 1896 a 1906, gdy „Willa pałacowa Młociny” należała do trzech osób pochodzenia żydowskiego ${ }^{65}$. Ma o tym świadczyć data umieszczona na fryzie południowego ryzalitu fasady pałacu (tj. MDCCCXCVIII) ${ }^{66}$. Według nas data na ryzalicie odnosi się jedynie do czasu remontu pałacu. Etap inwestycji polegający na rozbudowie oficyn zrealizowano prawdopodobnie później, dopiero po nabyciu praw własnościowych do posesji przez Stefana Antoniego Grodzickiego (po 1906 r. ${ }^{67}$ lub nawet w okresie dwudziestolecia międzywojennego. Wiadomo, że wykonano wtedy także dalsze przeróbki pałacu będącego w dzierżawie, w celu dostosowania go do potrzeb funkcjonującej tu restauracji ${ }^{68}$. Przebudowę z tego czasu obrazuje niedatowany, choć powstały najprawdopodobniej w drugiej dekadzie XX w. plan założenia nieznanego autora, uważany wcześniej przez D. Pape za projekt modernizacji, podkład geodezyjny ${ }^{69}$. Podano na nim imię

${ }^{64}$ Pustoła-Kozłowska E. 1991, s. 9.

65 Spacerownik. 2009, s. 20.

${ }^{66}$ Por. Spacerownik. 2009, fot. z 1916 r., ryc. nienumerowana na s. 21; Sokołowska-Grzeszczyk K. 1962, s. 133.

${ }^{67}$ Od roku 1906 Stefan A. Grodzicki był jednym z trzech współwłaścicieli nieruchomości, a następnie wykupił pozostałe udziały, Zieliński J. 2016, s. 216.

${ }_{68}$ Sokołowska-Grzeszczyk K. 1962, s. 134.

69 Pape D. 2008, s. 16-17. Autorka podaje, że w okresie międzywojennym dokonano odbudowy oficyny drugiej prawej drewnianej, lecz uległa ona spaleniu w 1936 r. Natomiast pozostałości fundamentów oficyny drugiej lewej istniały jeszcze przed II wojną światową. D. Pape powołuje się tu na relację ustną Władysława Miecznikowskiego, mieszkańca Młocin, co trudno uznać za w pełni wiarygodne źródło informacji. Być może chodzi tu o pożar, który wybuchł w pałacu w 1934 r., wzmiankowany w prasie (por. Olbrzymi pożar. 1934). 


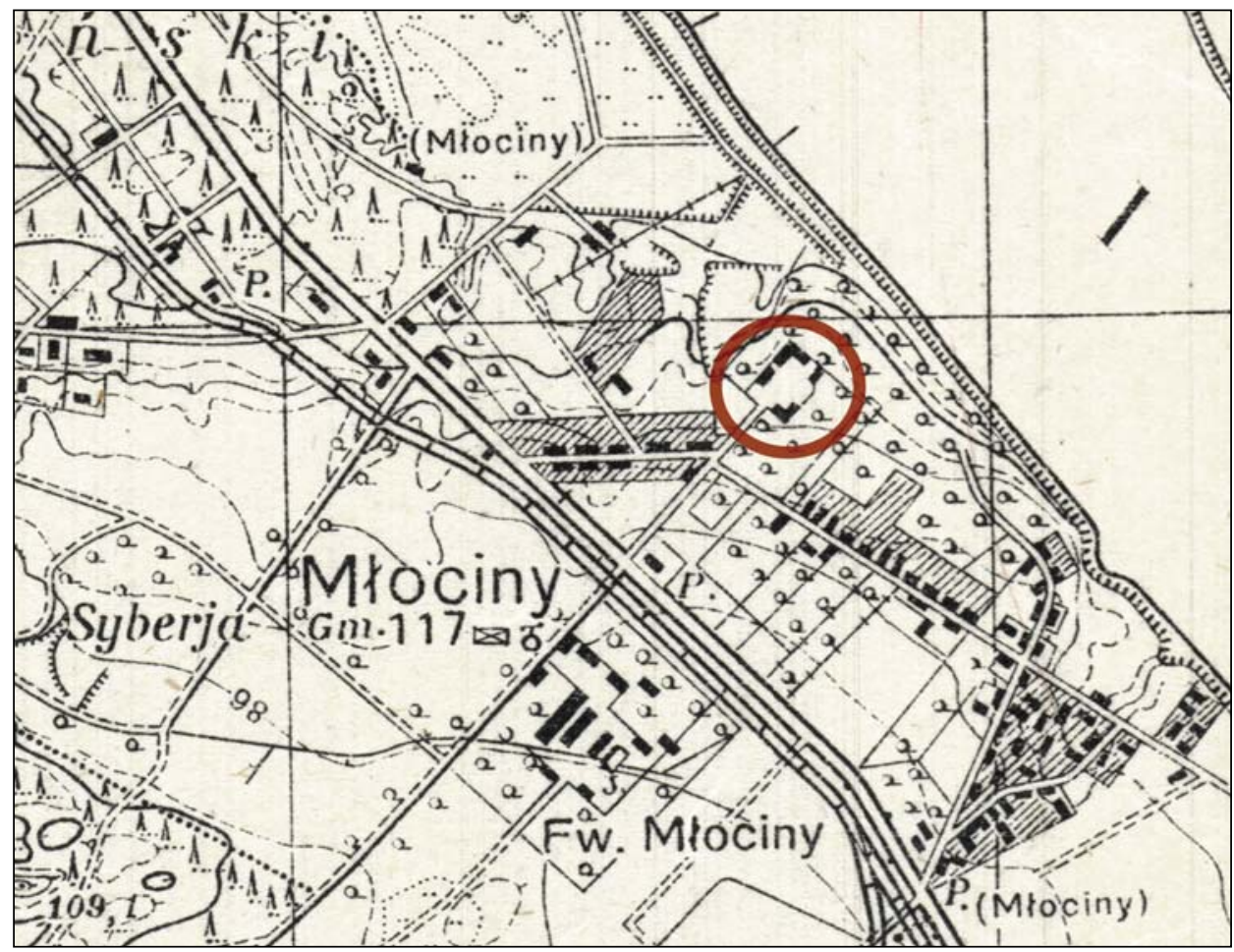

Ryc. 11. Założenie pałacowo-ogrodowe w Młocinach według mapy PAS 39-SEUP $32-G$ Warszawa-Żoliborz z 1936 r., fragment (za: Warszawa-Żoliborz. 1936; oprac. W. Bis); czerwonym kolorem oznaczono lokalizację pałacu z najbliższymi zabudowaniami

Fig. 11. The palace and garden in Młociny after the map PAS 39-SEUP 32 - G Warszawa-Żoliborz from 1936, a fragment (after: Warszawa-Żoliborz. 1936; compiled by W. Bis); the red colour marks the palace with its precincts

i nazwisko właściciela posesji — Stefana Grodzickiego, a główną budowlę określono jako „Pałac Grodzicki”. Zaznaczono tu zarysy czterech oficyn o podobnym kształcie i usytuowaniu, z czego każdą nazwano „Dom mieszk[alny] Mur[owany] I”. Trzy z nich zaopatrzono w czworoboczne werandy; pary oficyn łączy łukowata konstrukcja, a towarzyszą im inne zabudowania gospodarcze $^{70}$ (ryc. 9).

Można również przyjąć, że wzmiankowane działania realizowano w tym okresie dwuetapowo — od ok. 1898 do ok. 1916 oraz od ok. 1916 do 1934 r. Przed 1916 r. nastąpił bowiem kres istniejących dotąd obu oficyn drugich. Końcową cezurę wyznaczają fotografie z tego roku, obecnie w zbiorach Instytutu Sztuki PAN w Warszawie oraz opublikowane w artykule prasowym w 1918 r., prezentujące omawiane założenie, na której obiekty te nie są widoczne ${ }^{71}$ (ryc. 10). Później obie oficyny drugie najpewniej zostały jednak odbudowane i funkcjonowały jeszcze w latach trzydziestych, chociaż brak danych na temat ich wyglądu oraz materiału, z jakiego je wówczas wzniesiono. Dokumentują to np. fotoplan z 1934 r. ze zbiorów Archiwum Państwowego w Warszawie oraz mapy obrazujące kompleks pałacowy w 1936 r., tj. PAS 39 - SEUP 32

${ }^{70}$ Pape D. 2008, plan 9; Bis M., Bis W. 2011-2012, s. 97, ryc. 7.

${ }^{71}$ Korotyński W. 1918, fot. nienumerowana na s. 223, Wjazd do pałacu w Młocinach. 


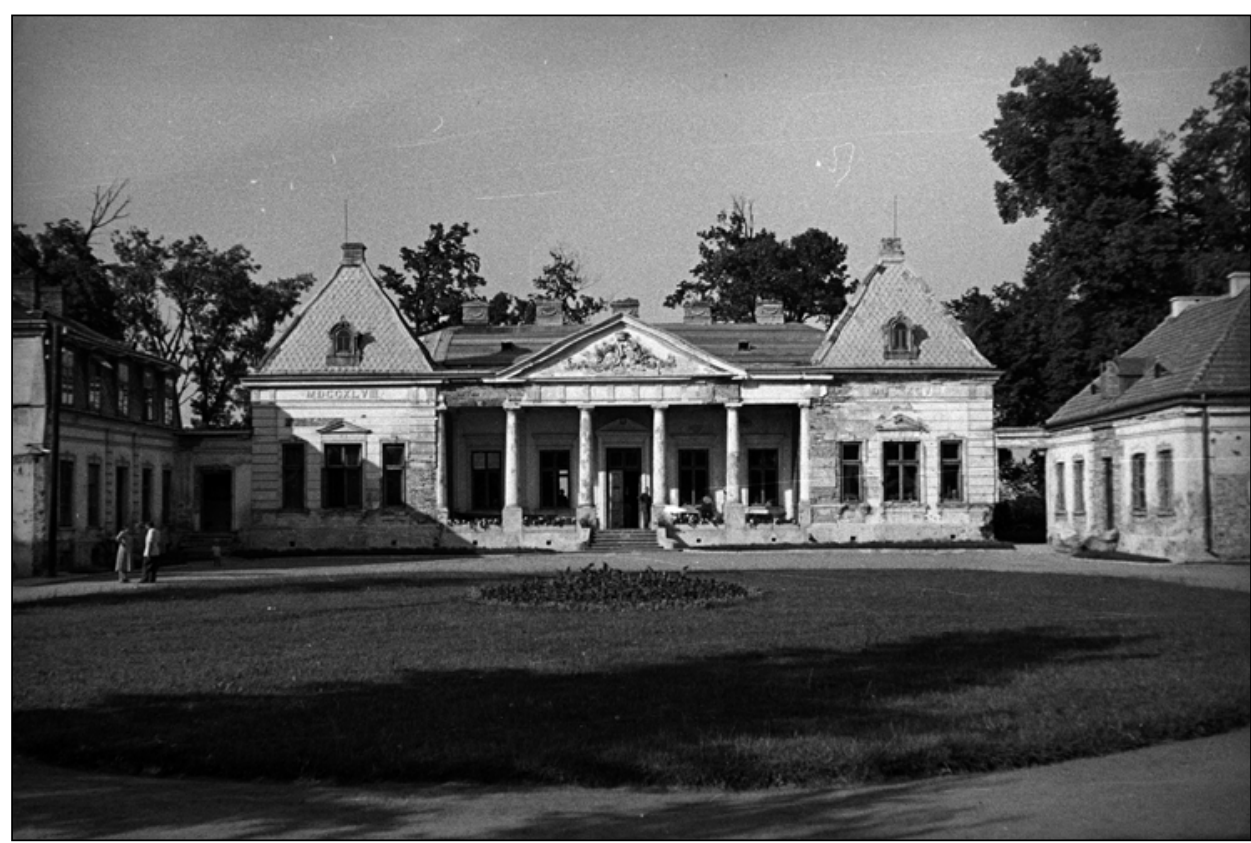

Ryc. 12. Pałac w Młocinach z oficynami pierwszymi, widok od południa, w obrębie dziedzińca, fotografia z lat 1945-1947 (fot. S. Rassalski, Narodowe Archiwum Cyfrowe)

Fig. 12. The palace in Młociny with the outhouses closer to the palace, a view from the south, within the courtyard, a photograph from 1945-1947

(by S. Rassalski, the National Digital Archive)

- G Warszawa-Żoliborz ${ }^{72}$ (ryc. 11) oraz w 1940 r., 3932 G Warschau Zoliborz ${ }^{73}$. Widnieje na nich kilka regularnych, prostokątnych budowli, w tym wszystkie oficyny — pierwsza lewa połączona $\mathrm{z}$ pałacem, za nią druga lewa oraz pierwsza prawa i dalej druga prawa; ta ostatnia $\mathrm{w}$ formie zarysu na lewo od bramy wjazdowej na posesję, złączona $\mathrm{z}$ innym budynkiem.

$\mathrm{Na}$ zdjęciu lotniczym wykonanym przez aliantów 26 lipca 1944 r. widoczne są już tylko oficyny pierwsze ${ }^{74}$. Można sądzić, że do zniszczenia drugich doszło w ciągu tych kilku lat. Drugą wojnę światową przetrwała oficyna pierwsza lewa w formie nadanej w XIX w. oraz pierwsza prawa wyglądem zapewne bardziej przypominająca budowlę z XVIII stulecia. W latach 1947-1948, w ramach przeprowadzonych wówczas prac mających na celu zabezpieczenie całego obiektu i dostosowanie go do potrzeb planowanej ekspozycji muzealnej (Muzeum Kultur Ludowych), na ocalałym, choć zniszczonym budynku oficyny pierwszej prawej usunięto nadbudowane piętro i przykryto ją ponownie dwuspadowym dachem z dachówki. Zmiany te dokumentują zdjęcia z lat 1947 i $1949^{75}$ (ryc. 12). Z 1947 r. pochodzi też sporządzona wtedy przez PP Pracownie Konserwacji Zabytków dokumentacja rysunkowa prezentująca rozmieszczenie wnętrz nie tylko w pałacu, ale też w oficynach pierwszych. Te ostatnie różniły się nieco między sobą podziałem funkcjonalnym przestrzeni ${ }^{76}$.

72 Warszawa-Żoliborz. 1936.

73 Warschau Zoliborz. 1940.

${ }^{74}$ Zieliński J. 2016, s. 212.

75 Zamieszczone w: Sokołowska-Grzeszczyk K. 1962, s. 134-135, [ryc.] 6-7.

76 Dokumentacja w Archiwum Instytutu Sztuki PAN, por. Szkurłat M. 2009, s. 126. 


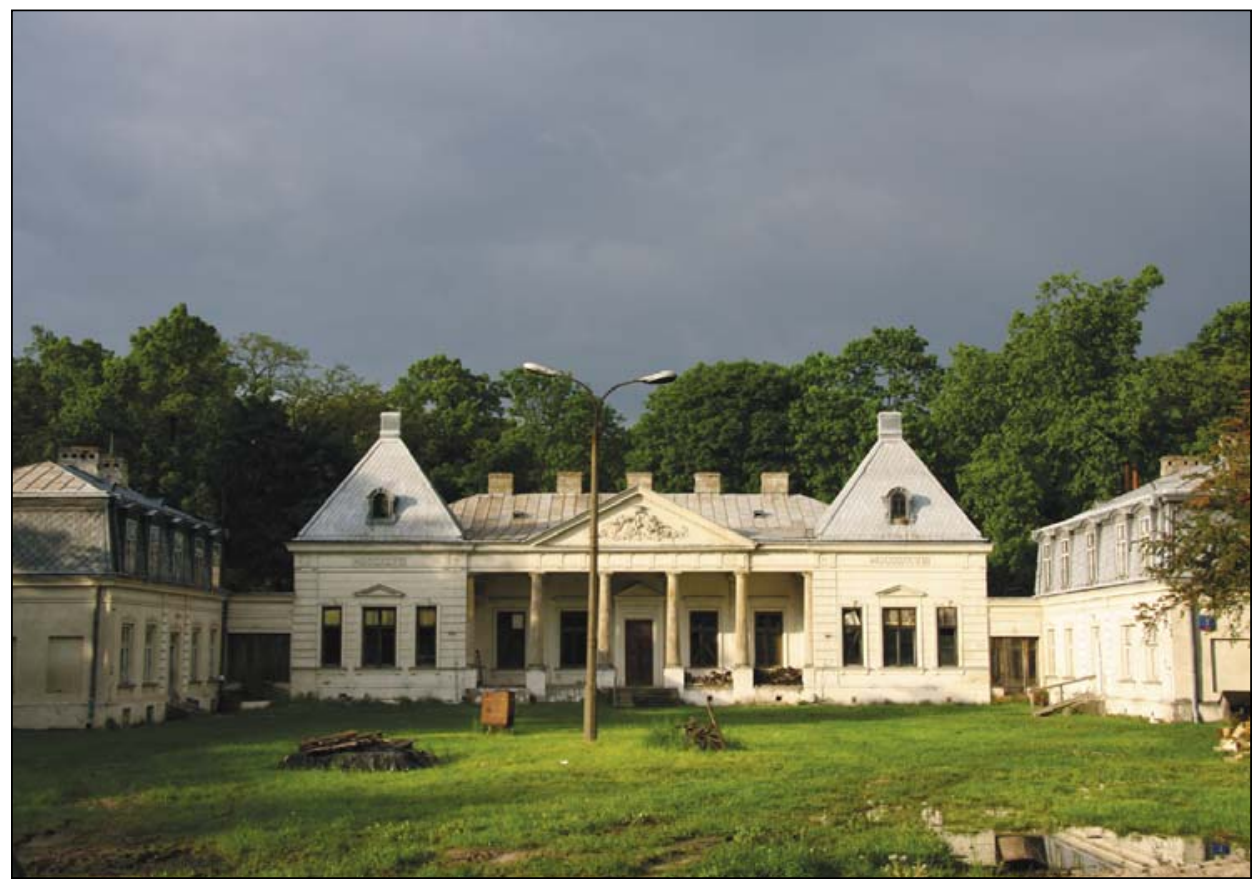

Ryc. 13. Pałac w Młocinach z oficynami pierwszymi, widok od południa, w obrębie dziedzińca, fotografia z 2010 r. (fot. W. Bis)

Fig. 13. The palace in Młociny with the outhouses closer to the palace, a view from the south, within the courtyard, a photograph from 2010 (by W. Bis)

W latach siedemdziesiątych XX w. prowadzono kolejne prace remontowe zarówno budynku pałacowego, jak i zachowanych oficyn, ale nie zostały one ukończone ${ }^{77}$. Z pewnością jednak oficynie pierwszej prawej przywrócono wtedy wygląd po przebudowie z końca XIX-początku $\mathrm{XX}$ w., tj. $\mathrm{z}$ mansardowym dachem krytym szarą blachą ${ }^{78}$. W takiej postaci zachowana jest do dnia dzisiejszego (ryc. 13). Obie oficyny pierwsze o późnobarokowej metryce istnieją współcześnie, lecz ich stan jest zły, a zniszczenie postępuje.

Prócz wspomnianych przekazów pisanych i ikonograficznych funkcjonowanie niezachowanych oficyn drugich potwierdziły ich relikty odsłonięte $\mathrm{w}$ toku prac archeologicznych przeprowadzonych na dziedzińcu pałacowym w 2010 r. Zlokalizowano je w linii istniejących, czyli pierwszych, w odległości ok. 34 m. Pozostałości oficyny drugiej lewej (północnej) przetrwały częściowo, w postaci fundamentu pod ścianę południową, zewnętrzną, łącznie na długości 6,9 m. Prawdopodobnie reszta została zniszczona w ostatniej ćwierci XX w., podczas niezrealizowanych prac budowlanych. Natomiast fundamenty pod oficynę drugą prawą (południową) przetrwały w dość dobrym stanie i pozwoliły na sformułowanie większości prezentowanych tu wniosków. Na podstawie obserwacji terenowych, w tym stratygrafii, techniki budowlanej oraz zajmowanej powierzchni, ustalono bezsprzecznie, że przynajmniej oficyna druga prawa istniała $\mathrm{w}$ dwóch różnych fazach chronologicznych, których początki dzieli około półtora stulecia — starszej, której początek przypada na drugą połowę XVIII w., i młodszej, od

${ }^{77}$ Kozłowska B. 2005, s. 10. Zakres tych prac nie został sprecyzowany.

${ }^{78}$ Pape D. 2008, s. 5. 


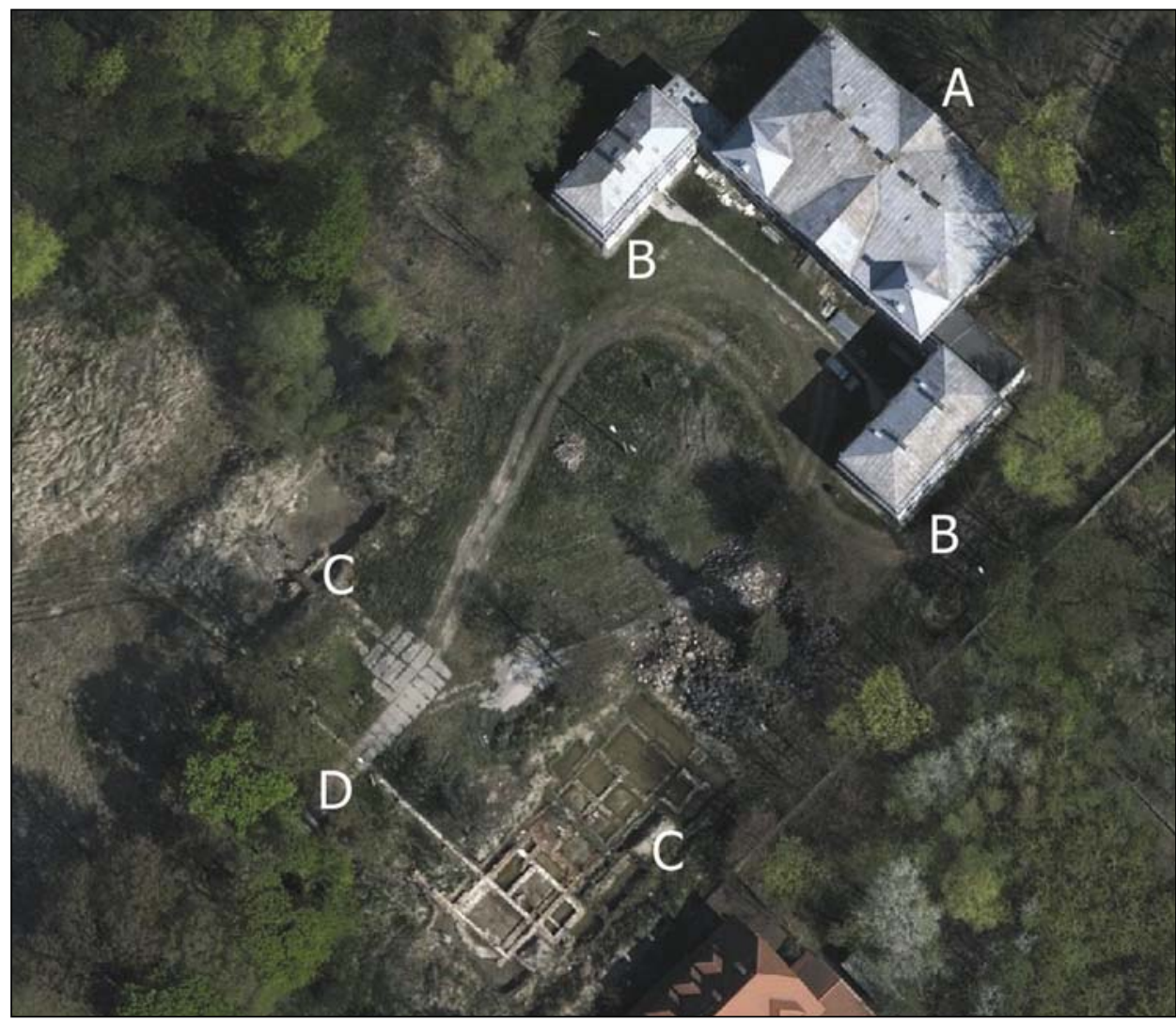

Ryc. 14. Fragment założenia pałacowo-ogrodowego w Młocinach, zdjęcie lotnicze, $2011 \mathrm{r}$.:

A — pałac; B - oficyny pierwsze; C — relikty zabudowań odsłonięte podczas badań archeologicznych w 2010 r.; D — lokalizacja reliktów przejazdu (fot. nieznany, portal Urzędu m.st. Warszawy; za: Muzealna. 2011; oprac. W. Bis)

Fig. 14. A fragment of the palace-and-garden complex in Młociny, an aerial photograph, 2011: A - the palace; B - the outhouses closer to the palace; C - relics of buildings excavated in 2010; D - relics of the passage (photographer unknown; the portal of the Municipal Council of Warsaw; after: Muzealna. 2011; compiled by W. Bis)

schyłku XIX lub na początku XX w. Niniejszym potwierdzają one, że obie wspomniane powyżej koncepcje architektoniczne zostały zrealizowane (ryc. 14).

Budynki będące inwestycją brühlowską i odkryte metodą archeologiczną miały rozmiar w planie oraz podział wewnętrzny zbliżony do wymiarów i układu istniejących nadal oficyn pierwszych. Krótszym bokiem usytuowane były równolegle do tych ostatnich a zarazem ku północy. Wymiary zewnętrzne oficyny drugiej prawej w tej fazie budowlanej wynosiły: 7,5 m szerokości (po linii wschód-zachód) i 16,5 m długości (w kierunku północ-południe). Zajmowała ona zatem ok. $124 \mathrm{~m}^{2}$ powierzchni. Wejście znajdowało się w środkowej części ściany szczytowej, od strony dziedzińca pałacowego i prowadziło do niewielkiej sieni (o szerokości wewnętrznej wynoszącej do $1,7 \mathrm{~m}$ i przedzielonej mniej więcej w połowie długości). Sień dzieliła oficynę na dwie odrębne części, o zróżnicowanym podziale przestrzennym, a wypełniało je łącznie pięć pomieszczeń w układzie amfiladowym. Trzy z nich usytuowane były na lewo od 

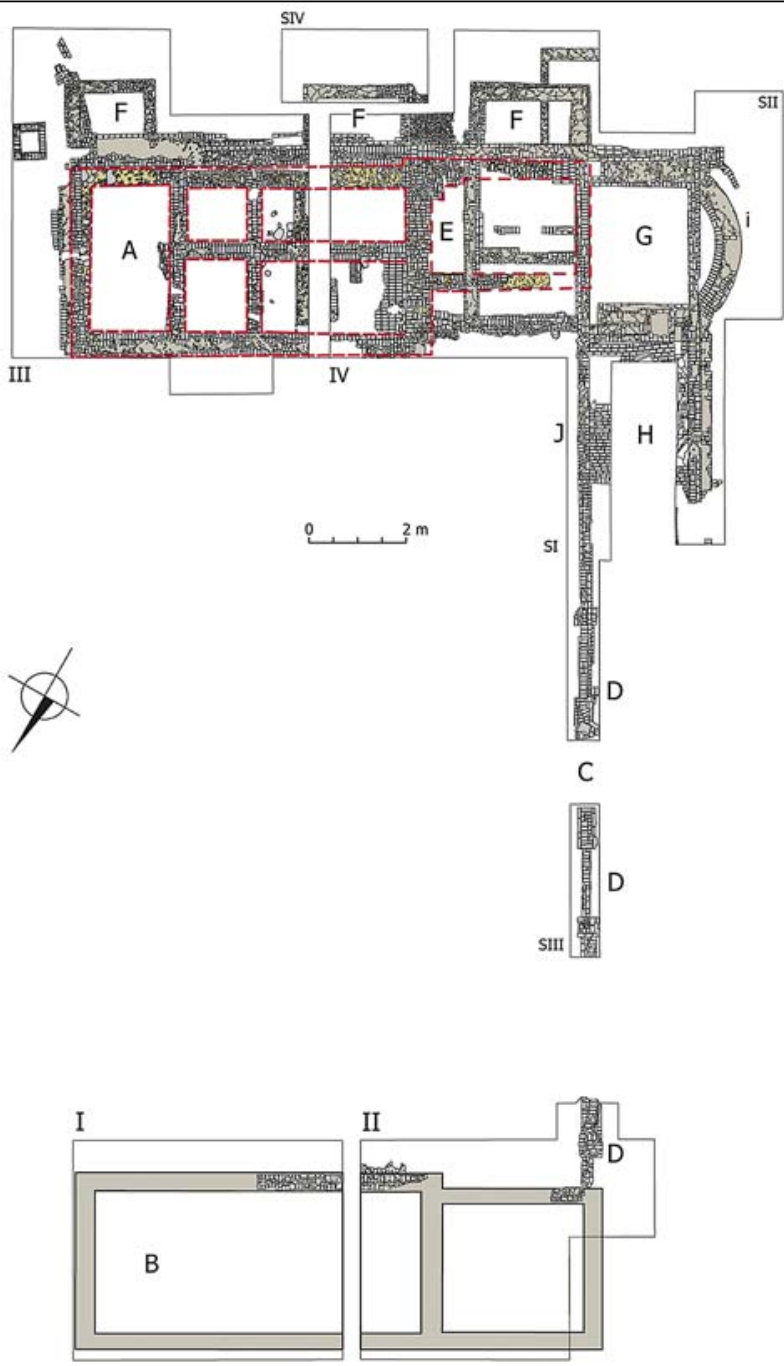

Ryc. 15. Relikty zabudowań z drugiej połowy XVIII w. i z końca XIX-początku XX w. przy pałacu w Młocinach, odsłonięte podczas badań archeologicznych w 2010 r.: A - oficyna druga prawa; B — oficyna druga lewa; C — przejazd na dziedziniec; D — ogrodzenie; E - mały budynek gospodarczy (?) (później mieszkalny); F — werandy; G — cieplarnia; H — stajnia i obora; I - taras; J — posadzka; I-IV — numery wykopów; SI-SIV — numery sondaży; linią przerywaną oznaczono zarys oficyny drugiej prawej z drugiej połowy XVIII w. (rys. M. Bis, W. Bis, W. Więckowski; oprac. W. Bis)

Fig. 15. Relics of buildings from the 2 nd half of the 18th c. and the late 19th-early 20th c. near the palace in Młociny, excavated in 2010: A - the right outhouse further from the palace; $\mathrm{B}$ - the left outhouse further from the palace; $\mathrm{C}$ - the passage to the courtyard; D — the wall; $\mathrm{E}$ - a small outbuilding (?) later used as living quarters; $\mathrm{F}$ - verandas; $\mathrm{G}$ - the greenhouse; $\mathrm{H}$ - the stable and the barn; I - a terrace; J - the floor; I-IV - the numbers of trenches; SI-SIV - the numbers of surveys; the dotted line marks the outline of the right outhouse further from the palace from the 2 nd half of the 18 th c. (drawn by M. Bis, W. Bis, W. Więckowski; compiled by W. Bis) 


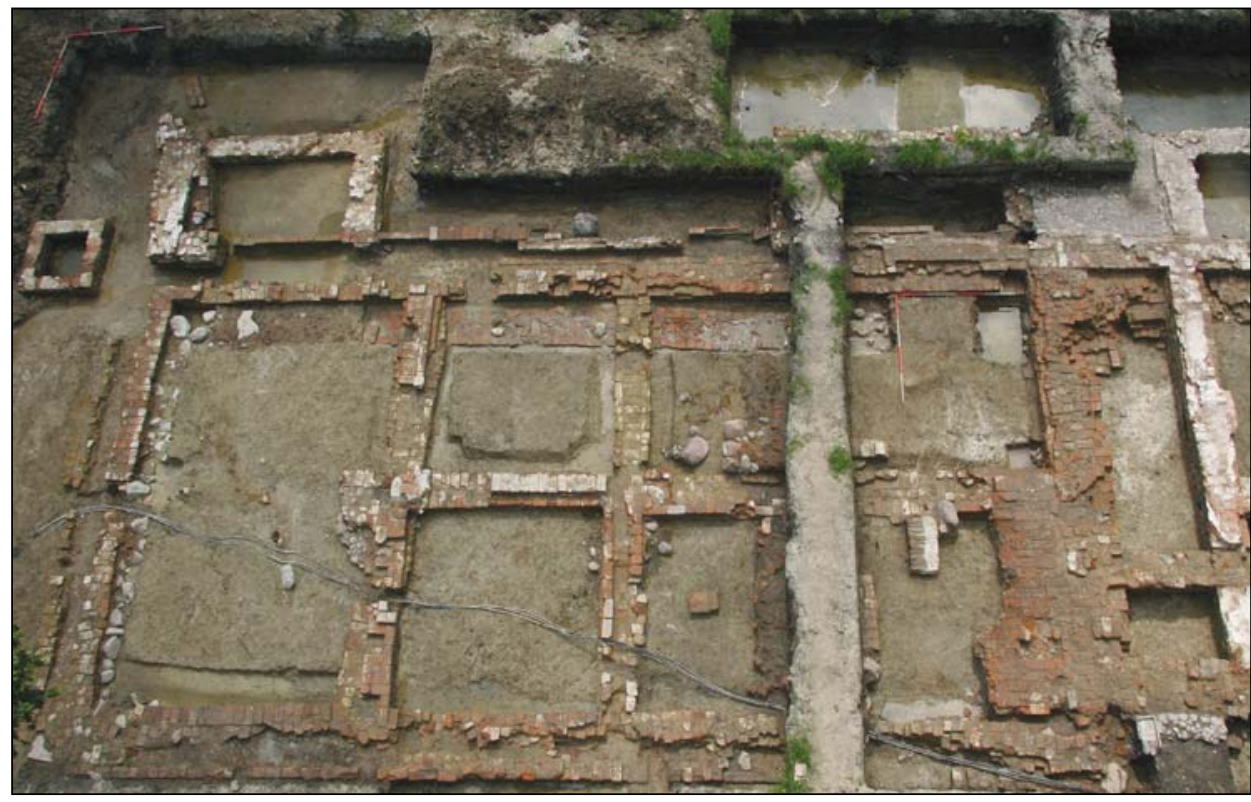

Ryc. 16. Relikty oficyny drugiej prawej z drugiej połowy XVIII w. i z końca XIX-początku XX w. przy pałacu w Młocinach, odsłonięte podczas badań archeologicznych w 2010 r., widok od północnego zachodu (fot. W. Bis)

Fig. 16. Relics of the right outhouse further from the palace from the 2 nd half of the 18 th $\mathrm{c}$. and the late 19th- early 20th c. near the palace in Młociny, excavated in 2010, a view from the north-west (photo by W. Bis)

sieni, o wymiarach wewnętrznych określonych na poziomie fundamentów $6 \times 3,7 \mathrm{~m}$ oraz $3 \times 3 \mathrm{~m}$ i 2,3×3 m, zaś dwa na prawo od niej, o wielkości $3 \times 3 \mathrm{~m}$ i 2,3×3 m. Odpowiadają one opisowi w inwentarzu z 1765 r., że w trzech oficynach znajdowały się wtedy prócz sieni po cztery pokoje i jedna „sala"79. Ta ostatnia to najpewniej owo najobszerniejsze wnętrze, o powierzchni ok. $22 \mathrm{~m}^{2}$, zaś każdy z pokoi to niewielkie lokum, po ok. 9 lub $7 \mathrm{~m}^{2}$ (ryc. 15:A).

Obie osiemnastowieczne oficyny drugie wzniesiono podobnie, na starannie przygotowanych fundamentach, zachowanych płytko poniżej współczesnego poziomu gruntu (ok. 20-50 cm). Podwaliny pod ściany zewnętrzne tych budynków miały przeciętnie $80 \mathrm{~cm}$ szerokości i wykonane zostały w wąskich wykopach budowlanych, przy użyciu niewielkich kamieni narzutowych (ok. 15-40 cm szerokości), których spoiwo stanowiła ruda glina i rozdrobniony gruz ceglany. Zachowany strop fundamentów stwierdzono na głębokości od 12,44 do 12,14 m n.p.0W, a spąg od 12,40 do 11,92 m n.p.0W. Podwaliny pod ściany działowe oficyny drugiej prawej miały zbliżoną szerokość $(70-75 \mathrm{~cm})$ i zrobione były wyłącznie z cegieł łączonych gliną. Cegły ułożone były dość różnorodnie, miejscami w wątku główkowym (ryc. 16-17). Na tak skonstruowanych fundamentach mogły powstać zarówno budowle drewniane, jak i murowane. Z uwagi na brak innych przesłanek, trudno stwierdzić, którą z tych wersji zrealizowano.

W formie nadanej w drugiej połowie XVIII w. oficyny drugie oraz pierwsze istniały zapewne do czasu kolejnych dużych prac remontowo-budowlanych u schyłku XIX lub na początku XX w., a najdłużej do roku 1916. Trudno jednoznacznie wskazać ówczesnego inwestora.

${ }^{79}$ Inwentarz. 1765, s. 67-69; Aneks. 


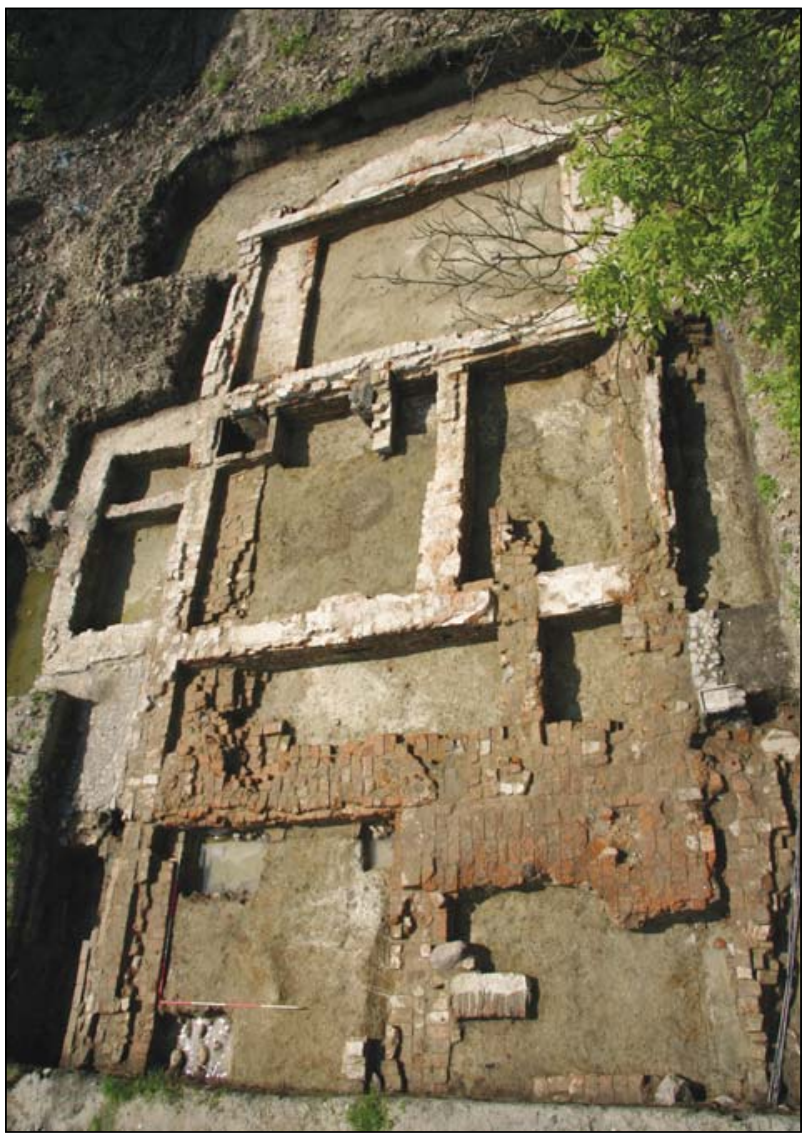

Ryc. 17. Relikty oficyny drugiej prawej, budynku gospodarczego (?) (później mieszkalnego) i cieplarni z tarasem z drugiej połowy XVIII w. i z końca XIX-początku XX w. przy pałacu w Młocinach, odsłonięte podczas badań archeologicznych w 2010 r., widok od północny

(fot. W. Bis)

Fig. 17. Relics of the right outhouse further from the palace, a small outbuilding (?) later used as living quarters and the greenhouse with a terrace from the 2 nd half of the 18 th $\mathrm{c}$. and the late 19th-early 20th c. near the palace in Młociny, excavated in 2010, a view from the north (photo by W. Bis)

Przed rokiem 1906 mogła to być nieznana z nazwiska osoba pochodzenia żydowskiego bądź w latach ok. 1906-1919 Stefan Antoni Grodzicki. Jeżeli wykonano je w kolejnym etapie, tj. po 1919 r., nastąpiło to w czasie, gdy założenie pałacowe należało już do jego spadkobiercy, Stefana Kazimierza.

Wtedy to, o czym wiadomo z przytaczanych powyżej archiwaliów, zmieniono wysokość oficyn pierwszych poprzez dodanie kolejnej kondygnacji, tym samym zwiększając kubaturę, oraz zmieniono konstrukcję i sposób pokrycia dachów. Czy analogiczna inwestycja objęła także oficyny drugie? Trudno to stwierdzić z powodu braku odpowiedniej dokumentacji. Jedyną wskazówką, iż była ona zaplanowana, stanowią symbole umieszczone na projekcie sporządzonym dla S. Grodzickiego, identyczne dla wszystkich czterech oficyn. To cyfra rzymska „I” prawdopodobnie oznaczająca budynki z jednym piętrem, w odróżnieniu od innych obiektów 
opisanych tu jako „Part.”, czyli parterowe ${ }^{80}$ (por. ryc. 9). Natomiast rezultaty przeprowadzonych wykopalisk umożliwiły ustalenie, że w wyniku podjętych wtedy prac przy oficynie drugiej prawej dokonano powiększenia powierzchni użytkowej budynku poprzez jego poszerzenie oraz dodanie od wschodu, czyli do dłuższej ściany, dwóch prostokątnych werand ${ }^{81}$, każdej o wymiarach 4,5×2,4 m. Oficyna, dzięki przesunięciu tylnej ściany o ok. 1,5 m na wschód na całej długości w stosunku do fundamentu z XVIII w. ${ }^{82}$, zyskała rozmiar $9 \mathrm{~m}$ szerokości na 16,5 m długości, czyli ok. $25 \mathrm{~m}^{2}$ powierzchni więcej na poziomie parteru. Pozostała część obrysu budowli pokrywała się ze starszym fundamentem (ryc. 15:A). Jej układ względem stron świata i odległość od oficyny pierwszej prawej nie uległy zmianie. Nadal był to także obiekt niepodpiwniczony. Realizacja ta wskazuje, że zachowując lokalizację oficyny w tym samym miejscu i powiększając ją w niewielkim stopniu, przy wykorzystaniu w głównej mierze istniejących fundamentów, kontynuowano osiemnastowieczne rozmieszczenie przypałacowych oficyn i dążono do utrzymania ich w zbliżonej wielkości, przynajmniej w zarysie.

Przesuniętą ścianę południową wykonano na bardzo płytko posadowionym i niestarannie wymurowanym ceglanym fundamencie, odkrytym na poziomie od 13,04 do 12,28 m n.p.0W (strop) oraz od 12,40 do 11,96 m n.p.0W (spąg). Cegły ułożone były bez wątku budowlanego, połączone zaprawą wapienną (ryc. 16-17). W wielu miejscach zastosowano tylko ceglaną oblicówkę, wnętrze konstrukcji wypełniając gruzem. Wydaje się, że na takim niestabilnym fundamencie powstały raczej ściany drewniane. Nie można jednak wykluczyć, że wzniesiono je w konstrukcji murowanej, jak zakładał plan dla Stefana Grodzickiego. Rozstrzygnięcie tej kwestii na podstawie dostępnych obecnie źródeł nie jest możliwe. Przeznaczenie nie tylko analizowanej, ale też pozostałych trzech oficyn miało być mieszkalne.

Inne budynki mieszkalne - ich powstanie w liczbie trzech zakładał projekt dedykowany S. Grodzickiemu, pochodzący przypuszczalnie z drugiej dekady XX w. Wszystkie określono identycznie jako „Dom mieszk[alny] mur[owany] part[erowy]”. Dwa z nich miały być zlokalizowane za oficynami drugimi, stanowiąc rodzaj aneksów wypełniających przestrzeń pomiędzy nimi a ogrodzeniem posesji od południa. Miały być nieduże, o kształcie czworobocznym, każdy z prostokątną werandą. Wejście do zabudowań miało prowadzić od strony dziedzińca (por. ryc. 9).

W trakcie prac archeologicznych odsłonięto pozostałości fundamentów tych obiektów, co dało podstawy do stwierdzenia, że również w tym zakresie przedstawione na wspomnianym rysunku elementy założenia zyskały realny kształt. Dom przylegający do oficyny drugiej lewej zachowany był szczątkowo; zidentyfikowano go jedynie w postaci fundamentu ściany wschodniej na długości 1,2-1,4 m. Z kolei obiekt towarzyszący oficynie drugiej prawej wzniesiono w tym samym miejscu co osiemnastowieczny budynek gospodarczy(?) (o czym także dalej), przy zachowaniu identycznej długości, tj. 6,5 m, lecz zwiększając szerokość do ok. 7,75 m. Jego powierzchnia wyniosła ok. $50 \mathrm{~m}^{2}$. Materiałem zastosowanym do budowy fundamentu ścian zewnętrznych były cegły o ciemnoczerwonym zabarwieniu, łączone zaprawą wapienną. Fundament o szerokości ok. $60 \mathrm{~cm}$ odsłonięto na poziomie 13,02-12,88 m n.p.0W (strop) do 12,32-12,54 m n.p.0W (spąg). Ceglaną ścianką działową na osi obiektu w jego wnętrzu wydzielono co najmniej dwa pomieszczenia. Od wschodu zarejestrowano zarys werandy o wielkości 4,5×2,4 m, czyli takiej samej jak te, które zbudowano przy oficynie drugiej prawej, a wedle wytycznych na przytaczanym projekcie dla Grodzickiego (por. ryc. 15-17). Na podstawie badań terenowych, z powodu braku wyższych partii konstrukcji nie ustalono, czy ściany

${ }^{80}$ Por. Bis M., Bis W. 2011-2012, s. 97, ryc. 7.

${ }^{81}$ Dodanie dwóch podobnych werand do budynku oficyny drugiej lewej (od zachodu) oraz jednej werandy do oficyny pierwszej prawej (od wschodu) przewidziano na niedatowanym planie przygotowanym dla S. Grodzickiego (por. Pape D. 2008, plan 9; Bis M., Bis W. 2011-2012, s. 97, ryc. 7). Nie wiadomo jednak, czy one powstały. Przy obecnej oficynie pierwszej prawej na powierzchni gruntu werandy brak, ale w miejscu, gdzie była planowana, zachowane są drzwi, które mogły do niej prowadzić.

${ }^{82}$ Linia fasady od strony dziedzińca, tzn. od zachodu, pozostała bez zmian. 
budynku wzniesiono $\mathrm{z}$ tego samego budulca co fundament. Jeżeli przyjmiemy, że został on postawiony zgodnie z projektem, to był to obiekt murowany, o jednej kondygnacji. Budynek ten prawdopodobnie można identyfikować $\mathrm{z}$ jednym $\mathrm{z}$ dwóch połączonych ze sobą prostopadle zabudowań, tworzących zarys w południowo-wschodnim narożniku młocińskiego założenia na schematycznie obrazujących je mapach z lat $1936^{83}$ (por. ryc. 11) i $1940^{84}$. Jeśli powstał po roku 1916, gdy wykonano fotografie, na których przy pałacu nie ma innych budynków poza oficynami pierwszymi, a uległ zniszczeniu pomiędzy 1940 a 1944 r. — data powstania wyżej wymienionej Topographische Karte i brytyjskiego zdjęcia lotniczego, to istniał ok. 30 lat.

Trzeci z analizowanych budynków przewidziano poza ogrodzeniem i bramą wjazdową, po lewej stronie alei wiodącej z pałacu w stronę szosy zakroczymskiej. Miał być budowlą prostokątną, parterową, dość wąską, także niewielką (por. ryc. 9). Miejsce jego lokalizacji nie zostało objęte pracami wykopaliskowymi, w związku z tym nie było możliwe zweryfikowanie wspomnianego planu, znalezienie materialnych śladów na potwierdzenie bądź zanegowanie istnienia tego obiektu.

B udy n k i gos podarcze powstały zarówno w drugiej połowie XVIII stulecia, jak i w końcu XIX lub na początku XX w.; prawdopodobnie razem było ich co najmniej pięć. Nie zostały one zaznaczone na osiemnastowiecznych planach młocińskiego założenia, mimo iż dwa $\mathrm{z}$ nich w tym czasie funkcjonowały. Zidentyfikowano je podczas badań archeologicznych przy obu oficynach drugich, do których ścian szczytowych zostały dostawione. Ich fundamenty odkryto przy oficynie drugiej lewej, zachowane w nikłym stopniu, na odcinku zaledwie 1,2-1,4 m, na głębokości od 12,50 m n.p.0W (strop konstrukcji) do 12,14 m n.p.0W (spąg). Wykonane były z cegieł łączonych na glinę, o szerokości ok. 50-60 cm. Były to obiekty nieduże, o wymiarach zewnętrznych ok. $5 \times 6,5 \mathrm{~m}$, czyli zajmujące po ok. $32,5 \mathrm{~m}^{2}$ powierzchni (por. ryc. 15-17). Prawdopodobnie wewnątrz miały po jednym pomieszczeniu, nie stwierdzono bowiem reliktów ścian działowych. Nie jest jednak wykluczone, że mogły być drewniane, umieszczone na poziomie gruntu i ślady po nich nie zachowały się. Fundamenty te nie były przewiązane $\mathrm{z}$ fundamentami oficyn, lecz na podstawie układu warstw kulturowych oraz analogicznego sposobu budowy można przyjąć, że powstały niedługo potem, czyli w przybliżeniu pomiędzy rokiem 1765 a 1790. Budynek zlokalizowany przy oficynie drugiej lewej przypuszczalnie istniał minimum 40 lat, gdyż został uwzględniony na mapach z lat $1819^{85} \mathrm{i} 1829^{86}$ (por. ryc. 5 i 7), a nie ma go na kolejnej, w miarę dokładnej z 1836 r. Można go identyfikować jako większy (na pierwszej z nich) lub dłuższy i węższy (na drugiej) od zabudowań interpretowanych przez nas jako oficyny. Niestety jego przeznaczenie nie jest znane. Drugi z budynków gospodarczych, przy oficynie drugiej prawej, nie został zaznaczony na wymienionych „kartach”; prawdopodobnie był już w tym czasie wyłączony z użytkowania.

Niezbędnym elementem dawnego założenia były z a b u dow a n i a folw a r c z n e. Stanowiły one jego gospodarcze zaplecze albo integralny element osiemnastowiecznych ogrodów krajobrazowych; w tym ostatnim przypadku o funkcji bardziej dekoracyjnej niż użytkowej ${ }^{87}$. Brak jednak podstaw, by rozstrzygnąć, która $\mathrm{z}$ nich tu dominowała. $\mathrm{O}$ tym, że istniały one w Młocinach w drugiej połowie XVIII w. wiadomo przede wszystkim z rejestru z $1765 \mathrm{r}^{88}$ Zawiera on podstawową charakterystykę tworzących go budynków i ich ówczesne przeznaczenie. Można je sytuować na północny zachód od głównego gmachu, „,na boku pałacu”. Budynek określony jako „folwark” mieścił sień, kuchnię, dwie izby i dwie komory. Poza tym stały tu trzy

83 Warszawa-Żoliborz. 1936

84 Warschau Zoliborz. 1940.

85 Environs de Varsovie [Młociny]. 1819.

${ }^{86}$ Plan okolic Warszawy. 1829.

$87 \mathrm{~W}$ tym ostatnim przypadku były one rodzajem sielskiej enklawy, miniaturką wiejskich gospodarstw, które w rzeczywistości pełniły funkcję rozrywkową dla właścicieli, Morawińska A. 1977, s. 66-67.

${ }^{88}$ Inwentarz. 1765, s. 70; por. Aneks. 


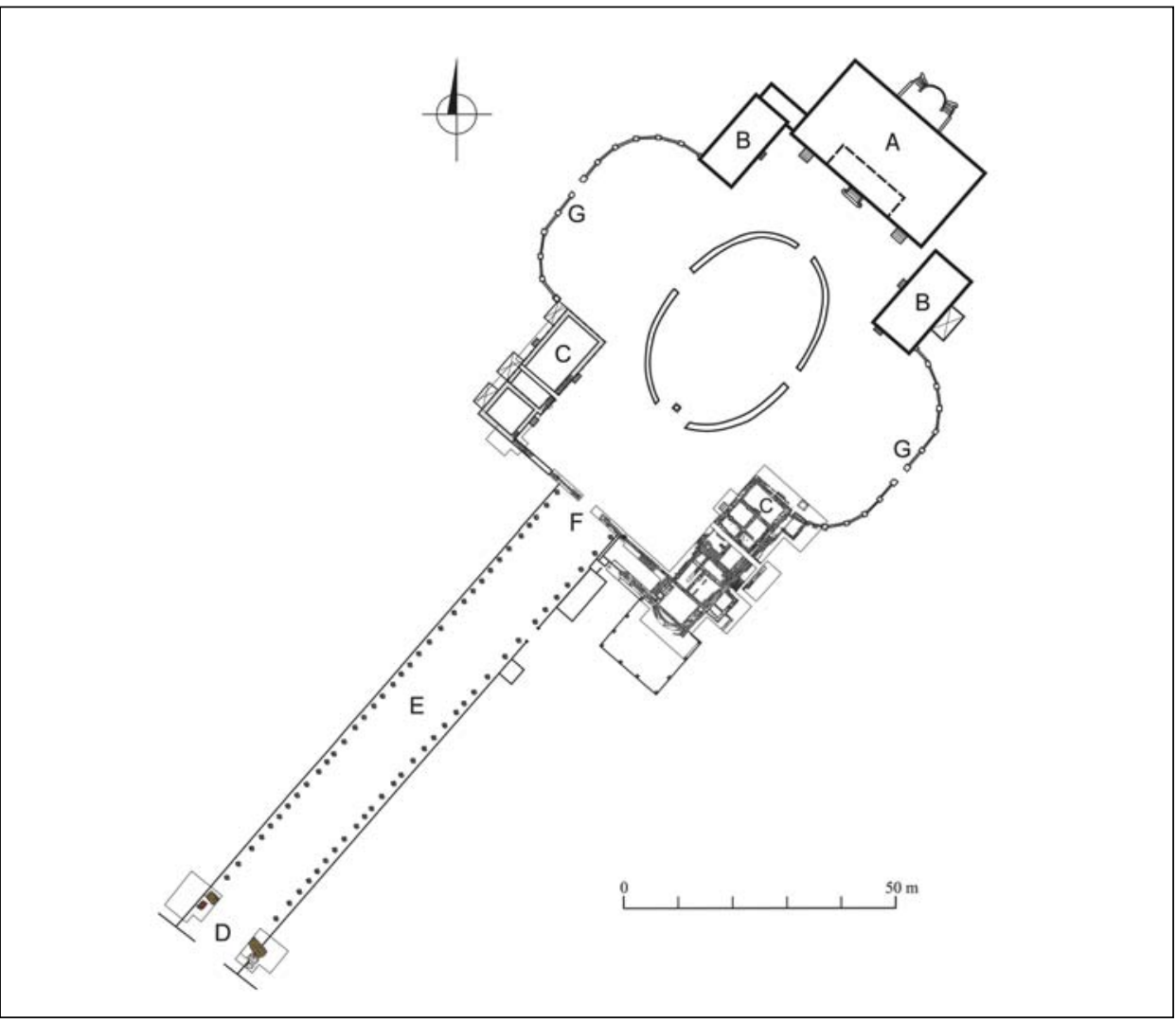

Ryc. 18. Relikty zabudowań z drugiej połowy XVIII w. i z końca XIX-początku XX w. przy pałacu w Młocinach, odsłonięte podczas badań archeologicznych w 2010 r., naniesione na projekt założenia dla Stefana Grodzickiego, niedatowany: A — pałac; B — oficyny pierwsze; $\mathrm{C}$ - oficyny drugie; D — brama-wjazd; E — aleja grabowa; F — przejazd na dziedziniec;

$$
\text { G - palisady (oprac. W. Bis) }
$$

Fig. 18. Relics of buildings from the 2 nd half of the 18th c. and the late 19th-early 20th c. near the palace in Młociny, excavated in 2010, marked on the undated design of the complex prepared for Stefan Grodzicki: A — the palace; B — the outhouses closer to the palace; C — the outhouses further from the palace; D - the entrance gate; E - the alley of hornbeams; F - the passage to the courtyard; $\mathrm{G}$ - palisades (compiled by W. Bis)

inne: kurnik, wozownia i stajnia. Wszystkie wzniesiono z drewna, w konstrukcji zrębowej, „folwark cały na fundamentach murowanych z drzewa tartego w węgły postawiony”. W przypadku stajni doprecyzowano, że zlokalizowana była za mostkiem. Rozmieszczenie i proporcje tych zabudowań względem siebie prezentuje Mappa Młocin ${ }^{89}$ (ryc. 3:2), na której widnieją one w niewielkiej odległości na zachód od oficyn lewych i palisady — pergoli. Trzy z nich dłuższą ścianą skierowane były ku północy i znajdowały się jeden za drugim, czwarty zaś w stosunku do nich prostopadle. Na podstawie przywoływanego opisu inwentarzowego można założyć, że najmniejszy z przedstawionych budynków, najbardziej wysunięty w stronę rzeki, to kurnik. Kolejny, największy to zapewne ów najważniejszy obiekt łączący rozmaite funkcje — kuchenno-

${ }^{89}$ Np. Putkowska J. 2016, s. 172-173, [ryc.] 111. 


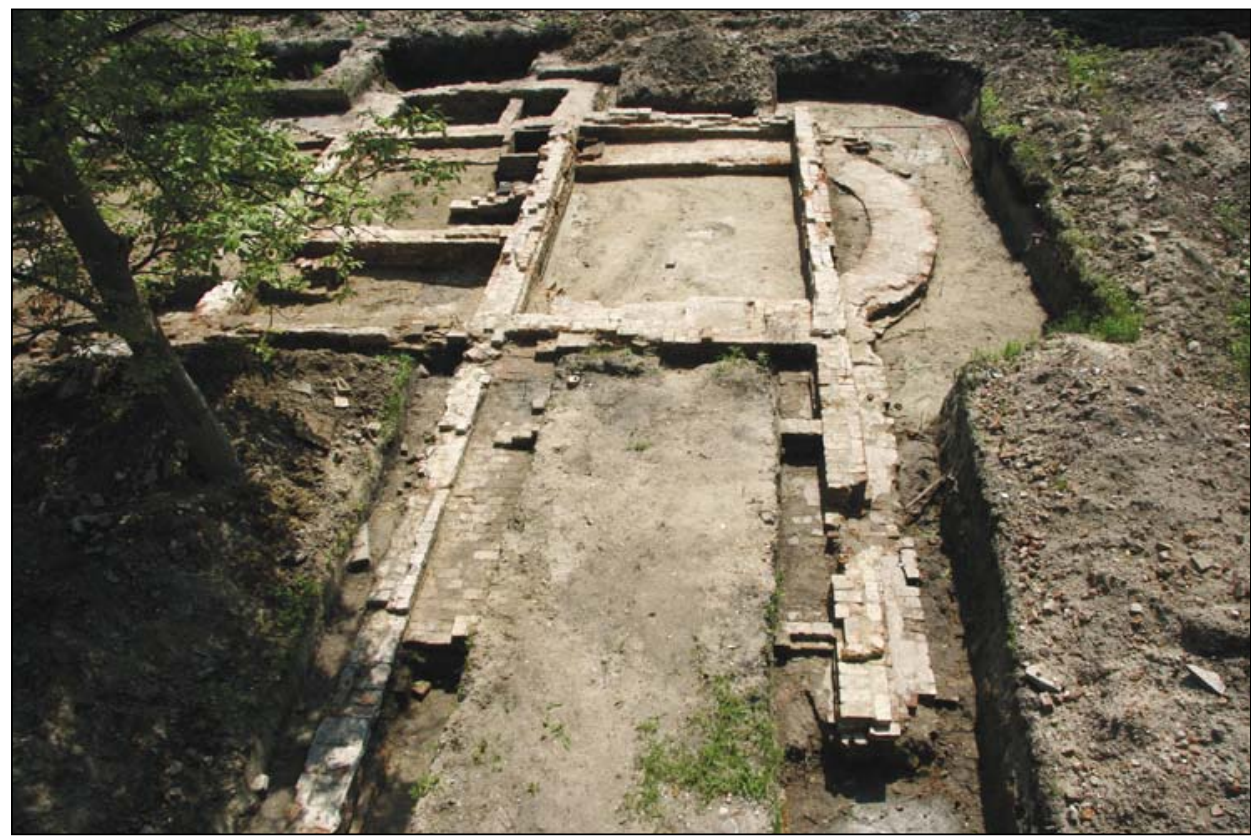

Ryc. 19. Relikty cieplarni z tarasem, stajni i obory oraz ogrodzenia z końca XIX-początku XX w. przy pałacu w Młocinach, odsłonięte podczas badań archeologicznych w 2010 r., widok od zachodu (fot. W. Bis)

Fig. 19. Relics of the greenhouse with a terrace, the stable, the barn and the wall from the late 19th-early 20th c. near the palace in Młociny, excavated in 2010, a view from the west (photo by W. Bis)

-magazynowe i mieszkalne (dla czeladzi). Stajnia przeznaczona była dla koni wierzchowych i pociągowych. W wozowni natomiast przechowywano rozmaite pojazdy wraz z wyposażeniem. Niestety nie dysponujemy innymi wiadomościami na ich temat. Częścią ówczesnego folwarku prawdopodobnie mogły też być położone w pobliżu, choć nie wzmiankowane w przywoływanym źródle, pola uprawne, łąka, staw, pasieka lub chmielnik ${ }^{90}$. Na początku XIX stulecia przeznaczenie wyżej wymienionych obiektów, o ile jeszcze funkcjonowały, mogło ulec zmianie w związku z przeniesieniem folwarku na większą odległość od pałacu, za trakt zakroczymski, po wycięciu części rosnącego tu drzewostanu. Zasięg zlokalizowanego tam nowego folwarku i jego zabudowę obrazuje np. mapa Environs de Varsovie [Młociny] z 1819 r. (wydana w 1820 r.) ${ }^{91}$ (por. ryc. 7), a jego rozwój kolejne dziewiętnastowieczne materiały kartograficzne.

Funkcjonowanie kompleksu w późniejszym okresie, tj. na początku XX w., według ,planu Grodzickiego" miały uzupełniać dwa dalsze zabudowania gospodarcze umiejscowione poza obrysem dziedzińca, których funkcję zdefiniowano na rysunku jako cieplarnia oraz obora i stajnia (por. ryc. 9 i 17). Te ostatnie przewidziano w obrębie jednego obiektu, dłuższego niż sąsiednia, połączona z nim szklarnia, ale o analogicznej szerokości. Ich obrysy odsłonięto podczas badań terenowych. Obiekty przylegały od zewnątrz do murowanego parkanu, a c i ep l a r n i a ponadto do jednej z węższych ścian małego budynku mieszkalnego (od południa). Miała kształt prostokątny, o wymiarach zewnętrznych 7,5 $\times 4,5 \mathrm{~m}$, tj. o powierzchni ok. $34 \mathrm{~m}^{2}$.

90 Morawinska A. 1977, s. 105-106.

91 Environs de Varsovie [Mlociny]. 1819. 
Fundament, o szerokości 50-60 cm z odsadzkami, zbudowano z cegieł łączonych zaprawą wapienną. W południowo-wschodnim narożniku budynku znajdował się wlot paleniska umożliwiający obsługę pieca, który ogrzewał wnętrze. Było to konieczne ze względu na przeznaczenie cieplarni do przechowywania lub hodowli i pielęgnacji roślin wrażliwych na zimno, nie nadających się do uprawy gruntowej w chłodnych porach roku. Niestety nie wiadomo, jakie gatunki tu trzymano (prawdopodobnie cytrusy). Był to budynek przeszklony ${ }^{92}$. Do cieplarni przylegał łukowaty fundament, będący przypuszczalnie reliktem półkolistego tarasu o rozmiarach ok. $7 \mathrm{~m}$ na maksymalnie 1,6 m, który został wraz $\mathrm{z}$ nią zbudowany i funkcjonował w tym samym czasie (ryc. 15:i; ryc. 19). Jeśli taras obudowany był lekką konstrukcją, mógł służyć jednocześnie jako zamknięta altana ${ }^{93}$, a cały obiekt pełnił funkcje użytkowo-ozdobne. Jak się wydaje, obrys tej budowli połączony z małym budynkiem mieszkalnym widnieje na dokumentacji kartograficznej z lat $1936^{94}$ (por. ryc. 11) i $1940^{95}$. Oba użytkowane były zapewne równocześnie, być może w latach 1916-1944.

Fundamenty s taj n i i o b o ry, murowane z cegieł przy użyciu zaprawy, odsłonięte zostały fragmentarycznie, ale pozwoliły na odtworzenie zewnętrznych wymiarów budynku, w którym się mieściły — ok. $11 \times 5 \mathrm{~m}$, czyli ok. $55 \mathrm{~m}^{2}$. Na podstawie sposobu jego budowy i relacji do sąsiednich obiektów określono, że funkcjonował on jednocześnie z innymi, wyżej wymienionymi zabudowaniami w okresie międzywojennym. Ponieważ brak go na mapach $\mathrm{z}$ drugiej połowy lat trzydziestych XX w., prawdopodobnie wtedy przestał już istnieć. W jego wnętrzu odsłonięto posadzkę z płasko ułożonych cegieł (ryc. 15:H, J; ryc. 19).

Do zabudowań gospodarczych, które wchodziły w skład omawianego założenia, należały także budynki c e g i e $1 \mathrm{n}$ i , w której prowadzono wyrób ceramicznych materiałów budowlanych, korzystając z lokalnych złóż. Została ona założona na północny zachód od pałacu, na wyniesieniu nad Wisłą. Działała z pewnością w ciągu XIX stulecia ${ }^{96}$, jej przybliżona lokalizacja została bowiem uwzględniona na kartografii z tego czasu. Na mapie opublikowanej w $1820 \mathrm{r}^{97}$ określono ją wprost jako „Dw[orska] Cegielnia” i oznaczono jako jeden budynek o wydłużonym kształcie (por. ryc. 7). Na dwóch innych planach powstałych po roku $1845^{98}$ (por. ryc. 6) i w 1875 r. ${ }^{99}$, sporządzonych dla armii carskiej, w odniesieniu do niej użyto nazwy w języku rosyjskim - Кирп[ичныци] Зав[од], a w tym rejonie wrysowano schematycznie pięć prostokątnych obiektów. Jej funkcjonowanie miało prawdopodobnie związek z zapotrzebowaniem na budulec podczas wznoszenia w tym czasie zabudowań folwarcznych usytuowanych na obszarze dawnego zwierzyńca. Nie można jednak wykluczyć, że cegielnia ma starszą metrykę, sięgającą drugiej połowy XVIII w., a jej założenie mogło być podyktowane budową tutejszego kompleksu pałacowego ${ }^{100}$. W miejscu, na którym umiejscowiono cegielnię w roku 1820, wry-

92 Por. Mały słownik. 1974, s. 85, hasło: Cieplarnia.

${ }_{93}$ Altana - niewielka budowla ogrodowa, zazwyczaj ozdobna w formie, drewniana lub murowana, otwarta lub zamknięta, często zwieńczona ozdobnym dachem, miejsce wypoczynku, osłona przez słońcem lub deszczem. Sytuowano je w punktach widokowych i w szczególnie malowniczych miejscach, Majdecki L. 1981, s. 903; 2007, s. 459; Pevsner N. i in. 1992, s. 15.

94 Warszawa-Żoliborz. 1936.

95 Warschau Zoliborz. 1940.

96 Zdaniem K. Sokołowskiej-Grzeszczyk miejscowa cegielnia była „stara, blisko dwustuletnia”, czyli ze sformułowania Autorki wynikałoby, że powstała po roku 1700. Teza ta nie została jednak uzasadniona, por. Sokołowska-Grzeszczyk K. 1962, s. 141-142.

97 Environs de Varsovie [Młociny]. 1819.

98 Plan okrestnostej goroda Varšavy. po 1845.

99 Karta Varšavskogo Učastka. 1875.

100 Mogło być to również wynikiem rozpoznania złóż surowców mineralnych przeprowadzonego na tym terenie przed rokiem 1777 przez geologa, Jean Philippe’a de Carosi, który badał nadwiślańskie skamieniałości w Młocinach i poświęcił im odrębną publikację (de Carosi J.P. 1777), o tym np. Waga A. 1843, s. 193-194; Korotyński W. 1918, s. 223; Sokołowska-Grzeszczyk K. 1962, s. 125. 
sowano także jeden budynek na starszej o kilkadziesiąt lat mapie Stanisława Gepperta ${ }^{101}$, obok ówczesnego folwarku (por. ryc. 3:3), a dwa na planie przypisywanym pruskiemu inżynierowi Rauchowi ${ }^{102}$ (por. ryc. 4). Brak innych wzmianek na temat cegielni uniemożliwia ustalenie wielkości, konstrukcji oraz dokładnej liczby tworzących ją obiektów. W XX w. nie była już użytkowana. Prawdopodobnie na początku tego stulecia pozostałe po niej glinianki zostały wykorzystane jako element wodny na uporządkowanym nabrzeżu Wisły, w obrębie Lasku Młocińskiego ${ }^{103}$. Zagłębienia terenu będące śladem po eksploatacji gliny zaznaczone zostały np. na Planie miasta stołecznego Warszawy i okolic z 1931 r. ${ }^{104}$ Obszar ten nie został jednak objęty pracami archeologicznymi.

$\mathrm{P}$ a l i s a d a — to konstrukcja będąca wyróżnikiem osiemnastowiecznego założenia pałacowo-ogrodowego w Młocinach. W opisie nieruchomości z 1765 r. odnotowana została jako ,palisada w słupach murowanych” lub ,palisady podmurowane”. Zgrupowana była w czterech miejscach - za bramą i pomiędzy oficynami, gdzie tworzyła „rzędów pięć”, „przęseł pięć” oraz dwukrotnie ,przęseł 10”105. Zakładając, że termin „przęsła” oznacza dwa połączone ze sobą elementy, słupów byłoby razem 60 .

Uwzględniono ją w postaci dwóch ćwierć łuków, z czego każdy z sześcioma słupami, prowadzących od oficyn ku przejazdowi, na niedatowanym projekcie S.B. Zuga ${ }^{106}$ (por. ryc. 2). W bardziej rozbudowanej formie została ona przestawiona na Mappie Młocin z ostatniej ćwierci XVIII stulecia ${ }^{107}$. Tu wyraźnie zobrazowano jej układ oraz poszczególne elementy (por. ryc. 3:1). Rozmieszczone były symetrycznie, po obu stronach dziedzińca. Stanowiły łączniki o kształcie półkolistym pomiędzy znajdującymi się w jednej linii oficynami, oraz tworząc ćwierć łuku pomiędzy oficynami drugimi a przejazdem. Materialnym śladem po tej konstrukcji jest odkryty wykopaliskowo niewielki odcinek łukowatego, ceglanego fundamentu, zachowanego na długości łącznie ok. 2,5 m, w postaci pięciu warstw cegieł łączonych gliną, o szerokości ok. 0,3 m, przy południowo-wschodnim narożniku oficyny drugiej prawej. Usytuowanie tego odcinka odpowiada fragmentowi palisady — pergoli wiodącej od tego budynku ku oficynie pierwszej. Fundament ten został przecięty przez podwalinę dwudziestowiecznej werandy (por. ryc. 9 i 16). Można założyć, że przestały one istnieć na początku wieku XIX, gdy dokonano przebudowy ogrodzenia w tej partii założenia; nie ma ich już bowiem na mapie z 1819 r. ${ }^{108}$ oraz kolejnych, dziewiętnastowiecznych (por. ryc. 5-8).

O tym, że stanowiły one ważny element młocińskiego kompleksu pałacowo-ogrodowego, świadczy projekt dla Stefana Grodzickiego z ok. drugiej dekady XX w., na którym zostały zrekonstruowane $^{109}$ (ryc. 9). Potwierdzeniem tej tezy są relikty czworobocznej podstawy pod jeden ze słupów, dostawione do narożnika werandy zbudowanej w tym samym czasie przy oficynie drugiej prawej i odsłonięte w toku niedawnych prac wykopaliskowych. Zbudowane były z czterech-pięciu warstw cegieł łączonych zaprawą, o wymiarach ok. 0,7x0,7 m. Te nowsze palisady zostały ukazane np. na planie z $1931 \mathrm{r} .^{110}$, natomiast na kolejnych — z 1936 (por. ryc. 11) i 1940 r. już ich brak. Prawdopodobnie zatem istniały ok. kilkunastu lat. Niestety nie

\footnotetext{
101 Np. Putkowska J. 2016, s. 172-173, [ryc.] 111.

102 Por. Weszpiński P. 2007, s. 58.

103 Sokołowska-Grzeszczyk K. 1962, s. 141-142.

104 Plan miasta stolecznego Warszawy i okolic. 1931.

105 Inwentarz. 1765, s. 67-68; Aneks.

106 Hentschel W. 1967, t. II, [ryc.] 455.

107 Np. Putkowska J. 2016, s. 172-173, [ryc.] 111.

108 Environs de Varsovie [Mlociny]. 1819.

109 Bis M., Bis W. 2011-2012, s. 97, ryc. 7.

110 Plan miasta stołecznego Warszawy i okolic. 1931.
} 
dysponujemy bliższymi danymi o ich wyglądzie, gdyż nie są one widoczne na znanej dokumentacji fotograficznej pochodzącej sprzed połowy ubiegłego stulecia.

Analizowana konstrukcja stanowiła zapewne rodzaj otwartej pergoli podtrzymującej pnącza, np. winorośl, wisterię (glicynię) lub róże, której podstawę stanowił rząd wspomnianych słupów ustabilizowanych ceglanym fundamentem, ustawionych w równych odległościach. $\mathrm{Na}$ nich mogły opierać się poziome belki, konstrukcja kratowa lub łukowata $\mathrm{w}$ formie galerii ${ }^{111}$. Taka konstrukcja mogła też tworzyć treliaż, czyli ażurową ścianę z kraty drewnianej, która obrośnięta pnączami stanowiła obramowanie ogrodowego wnętrza ${ }^{112}$. Jeżeli zaś słupy nie podtrzymywały belkowania, to tworzyły rodzaj kolumnady - wertykalnych, dobrze wyeksponowanych elementów, nawiązujących do antycznych kolumn ${ }^{113}$. Użyte w źródle określenie ,palisada" wskazuje na zastosowanie do jej budowy drewna, zaś sformułowanie „przęsła”, że mamy tu do czynienia z połączonymi pionowymi podporami. Bez wątpienia miała ona funkcję dekoracyjną; pergole były popularnym elementem europejskiej architektury ogrodowej zwłaszcza w dobie nowożytnej ${ }^{114}$.

B ra m y i o grodze n i e. Brama stanowiła ważny element kompozycji założeń pałacowo-ogrodowych i ogrodowych począwszy od epoki renesansu. Zamykała przejazd, zwykle wyposażona była w dwuskrzydłowe wrota, mogła być bogato zdobiona albo miała formę odrębnej budowli ${ }^{115}$. Zidentyfikowano ją także wykopaliskowo przy omawianym założeniu, obok współczesnego wjazdu, co świadczy też o trwałości tej granicy posesji (por. ryc. 1:D). To zarazem rejon skrzyżowania alei wytyczonej od młocińskiej rezydencji w stronę południową, która dawniej prowadziła do sąsiedniego zwierzyńca (współcześnie to ulica Muzealna, przechodząca w ulicę Heroldów), z drogą, która wiodła z Warszawy i skręcała w tym miejscu nieznacznie na południowy zachód, w stronę Zakroczymia (to dzisiejsza ulica Farysa). Przebieg pałacowej alei, „grabowym drzewem sadzonej ulicy”, jak opisano ją w 1765 r., oraz duktu zakroczymskiego nie uległy bowiem zmianie od ok. połowy XVIII stulecia. Kolejna brama zamykała dziedziniec (ryc. 18:D, F).

Elementy te nie zostały uwzględnione na analizowanych osiemnastowiecznych i dziewiętnastowiecznych przedstawieniach topograficznych. Informuje o nich przywoływany „Inwentarz wsi Młocin [...]”. W relacji odnotowano: „Wjazd alias brama podwójna w słupach na zawiasach i hakach potrójnych” oraz „brama takaż podwójna w cyrkuł u wierzchu dana, przy której fortka $[\ldots]^{\prime \prime 116}$. To jedyne wzmianki znane ze źródeł pisanych. Materialne dowody ich istnienia uzyskano w wyniku badań archeologicznych (ryc. 18:D, F). Dzięki temu sprecyzowano również ich położenie i sposób budowy ich fundamentów. Na północ od współczesnego wjazdu na teren założenia, na głębokości ok. $0,8 \mathrm{~m}$ od obecnego poziomu gruntu, odsłonięto murowane relikty zachowane na poziomie od 13,24 m n.p.0W (strop) do 12,62 m n.p.0W (spąg), przebiegające z zachodu na wschód. Konstrukcja ta wykonana była z cegieł spojonych gliną, ułożonych głównie w wątku główkowym. Jej szerokość wynosiła 1,5 m, a łączna długość ponad 11,5 m. Odkryto ją w dwóch odrębnych odcinkach, o długości 1,9 m i 2,9 m. Przebadanie miejsca ich połączenia nie było możliwe, ponieważ znajdowało się ono pod dzisiejszym przejazdem (ryc. 20:A). Można przyjąć, że są to pozostałości najstarszej bramy, prawdopodobnie mającej postać masywnej konstrukcji. Technika wykonania tego fundamentu była analogiczna jak oficyn

111 Por. np. altana na projekcie J.Ch. Kamsetzera z ok. 1780 r. dla ogrodu przy rezydencji Stanisława Augusta Poniatowskiego w Ujazdowie, Putkowska J. 2016, s. 245, [ryc.] 155.

112 Treliaże były charakterystyczne zwłaszcza dla okresu baroka, Majdecki L. 2007, s. 465, hasło: Treliaż; Pevsner N. i in. 1992, s. 367, hasło: Treliaż.

113 Harrison L. 2011, s. 205.

114 Por. Majdecki L. 1981, s. 910; 2007, s. 463-464; Böhm A., Zachariasz A. 2005, s. 195-196, 205.

115 Pevsner N. i in. 1992, s. 62; Majdecki L. 2007, s. 460, hasło: Brama.

116 Inwentarz. 1765, s. 67, 68; Aneks. 


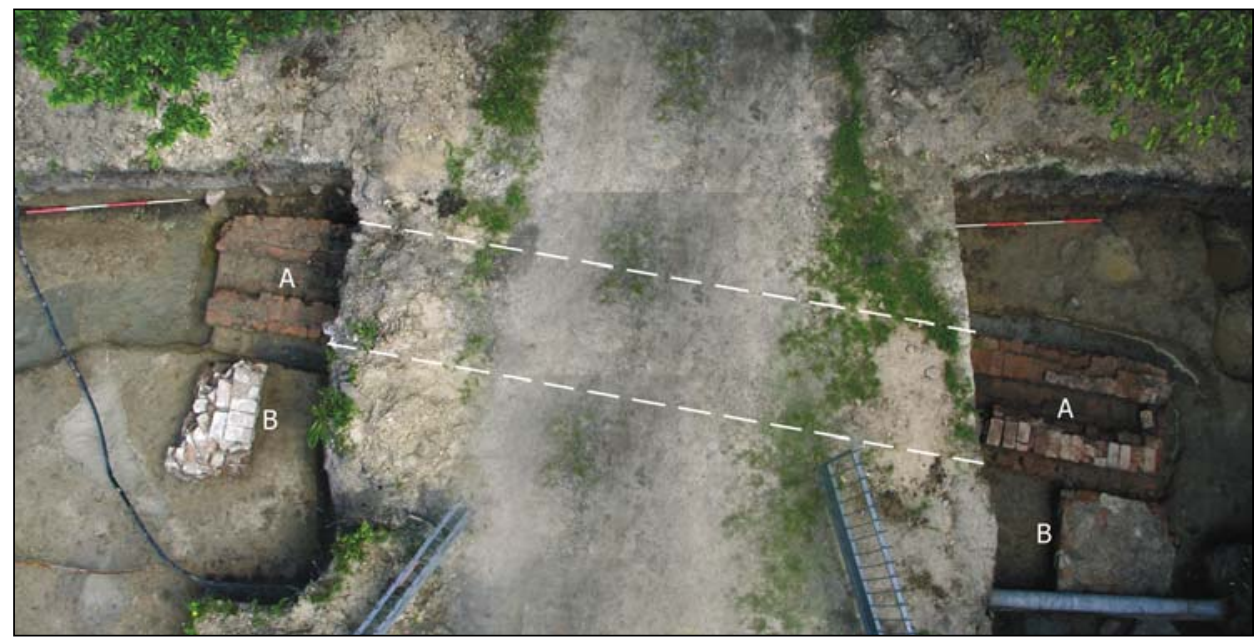

Ryc. 20. Relikty bramy-wjazdu z drugiej połowy XVIII w. przy pałacu w Młocinach, odsłonięte podczas badań archeologicznych w 2010 r., widok od południa: A — brama starsza; linią przerywaną oznaczono rekonstruowany przebieg konstrukcji; B — brama młodsza, z filarami (fot. i oprac. W. Bis)

Fig. 20. Relics of the entrance gate from the 2 nd half of the 18 th c. at the palace in Młociny, excavated in 2010, a view from the south: A - the older gate; the dotted line marks the reconstructed course of construction; B - the newer gate with pillars (photographed and compiled by W. Bis)

i towarzyszących im budynków, wzniesionych w drugiej połowie XVIII stulecia. Być może pochodzą one z okresu sprzed modernizacji przypisywanej S.B. Zugowi, gdy główny dojazd do rezydencji prowadził jeszcze od północy — od strony miasta Wisłą lub drogą przez wieś nad rzeką (dzisiejsza ulica Prozy), jak wskazują projekty z ok. 1752 r. ${ }^{117}$ Analizowany tu obiekt zamykałby założenie od strony południowej.

$\mathrm{Na}$ zachód od tych reliktów odsłonięto dwa kolejne, niewielkie i zniszczone fundamenty w postaci dwóch rzędów cegieł łączonych na zaprawę wapienną, o szerokości 1,4 m i zachowane na długości $1,2 \mathrm{~m}$ oraz $0,8 \mathrm{~m}$. Rozmieszczone były także w odległości 11,5 m. Odsłonięto je na głębokości od 13,14 do 12,90 m n.p.0W (ryc. 20:B; ryc. 18:D) Przypuszczalnie są to pozostałości zewnętrznych filarów bramnych, między którymi znajdowały się zapewne dwa filary dodatkowe, określające właściwą szerokość tego przejazdu. To te elementy mogą, według nas, odpowiadać pierwszemu cytowanemu przekazowi, czyli „Wjazd alias brama”. Przypuszczać można, że to pozostałości konstrukcji bramnej z ok. 1765-1790 r., gdy doszło do zmiany aranżacji przestrzennej w otoczeniu rezydencji, w tym umiejscowienia wjazdu, który odtąd znajdo-

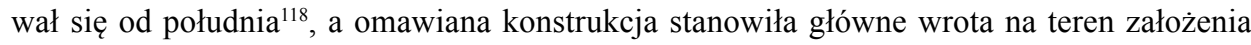
pałacowo-ogrodowego. Były one zapewne wkomponowane w ogrodzenie, jakie w tym czasie mógł tu tworzyć roślinny żywopłot ${ }^{119}$. Bramy złożone ze słupów, niekiedy połączone nadprożem

117 Putkowska J. 2016, s. 174.

118 Np. Pustoła-Kozłowska E. 1991, s. 7.

119 Zastosowanie takiego ogrodzenia spośród innych (w formie muru, z desek, jaki tworzyła rzeka lub fosa), zalecał np. August Fryderyk Moszyński w Rozprawie o ogrodnictwie angielskim z 1774 r. (Morawińska A. 1977, s. 98), uzasadniając, że wydziela ono „ogród wiejski od wielkiego lasu albo pól, do których dotyka, wzrok przeto nie napotyka przeszkody, [a] imaginacja podejmuje wysiłek". 


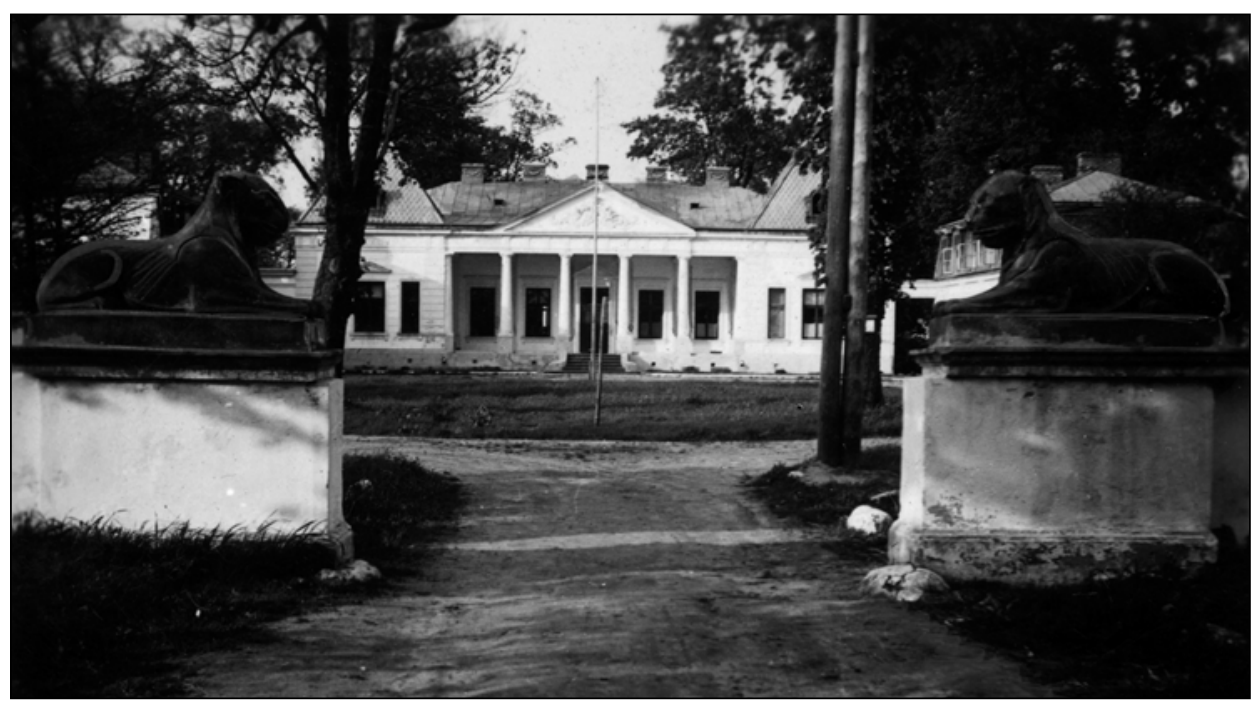

Ryc. 21. Pałac w Młocinach z oficynami pierwszymi i przejazdem na dziedziniec, widok od południa, fotografia z 1942 r. (fot. nieznany, Narodowe Archiwum Cyfrowe)

Fig. 21. The palace in Młociny with the outhouses closer to the palace and the passage to the courtyard, a view from the south, a photograph from 1942 (photographer unknown, the National Digital Archive)

lub łukiem, zwieńczone ozdobnymi elementami, np. sterczynami, urnami, figurami zwierząt, były ważnym elementem dekoracyjnym $\mathrm{w}$ projekcie ogrodu ${ }^{120}$. Wydzielały one teren posesji, a głównym ich elementem były dwa murowane, wysokie słupy oraz umocowane pomiędzy nimi metalowe, ruchome i ażurowe skrzydła. Konstrukcje takie znane są np. z istniejącego dotychczas pałacu Brühla w miejscowości Brody oraz z archiwalnych widoków budowli przy ul. Wierzbowej w Warszawie ${ }^{121}$.

Drugi przejazd stanowił rodzaj wewnętrznego podziału. Znajdował się pomiędzy aleją grabową a dziedzińcem pałacu. Zlokalizowano go w miejscu, gdzie w drugiej połowie XVIII w. zaczynały się palisady — pergole przebiegające po ćwierć łuku do oficyn drugich, i dopełniał kompozycji przestrzennej zamykając regularny kształt trójliścia utworzony w planie z trzech elementów: pałac — oficyny — palisady. Dotyczą go słowa: ,idąc dalej [...] palisad podmurowanych przęseł 10 , w których brama takaż podwójna $\mathrm{w}$ cyrkuł ${ }^{122} \mathrm{u}$ wierzchu dana, przy której furtka"123. Analizowany przejazd zaznaczono schematycznie na mapie Stanisława Gepperta z ostatniej ćwierci XVIII w. Z czasem, po likwidacji rozmieszczonych tu palisad, zamiast owej ozdobnej konstrukcji powstało tu ogrodzenie tradycyjne, wytyczone w linii prostej od oficyn drugich, dalej wiodące ku omawianemu przejazdowi ${ }^{124}$. Zaznaczono je w ten sposób na przedstawieniach kartograficznych z pierwszej połowy XIX w. Przebieg ogrodzenia w tym rejonie założenia, jak wskazują zachowane źródła ikonograficzne, nie uległ zmianie po XX w.

${ }^{120}$ Pevsner N. i in. 1992, s. 63; Harrison L. 2011, s. 211.

121 Bis M., Bis W. 2011-2012, s. 96; por. Hentschel W. 1967, t. I, [ryc.] 72, oraz projekty bramy głównej J.F. Knöbla dla tego pałacu, Hentschel W. 1967, t. II, [ryc.] 512-513.

122 Cyrkuł - okrąg, kolisty kształt (Słownik Polszczyzny. 2010-2019). W tym przypadku oznacza bramę zamkniętą łukiem.

${ }^{123}$ Inwentarz. 1765, s. 68; por. Aneks.

124 Na ten temat także Pustoła-Kozłowska E. 1991, s. 10. 


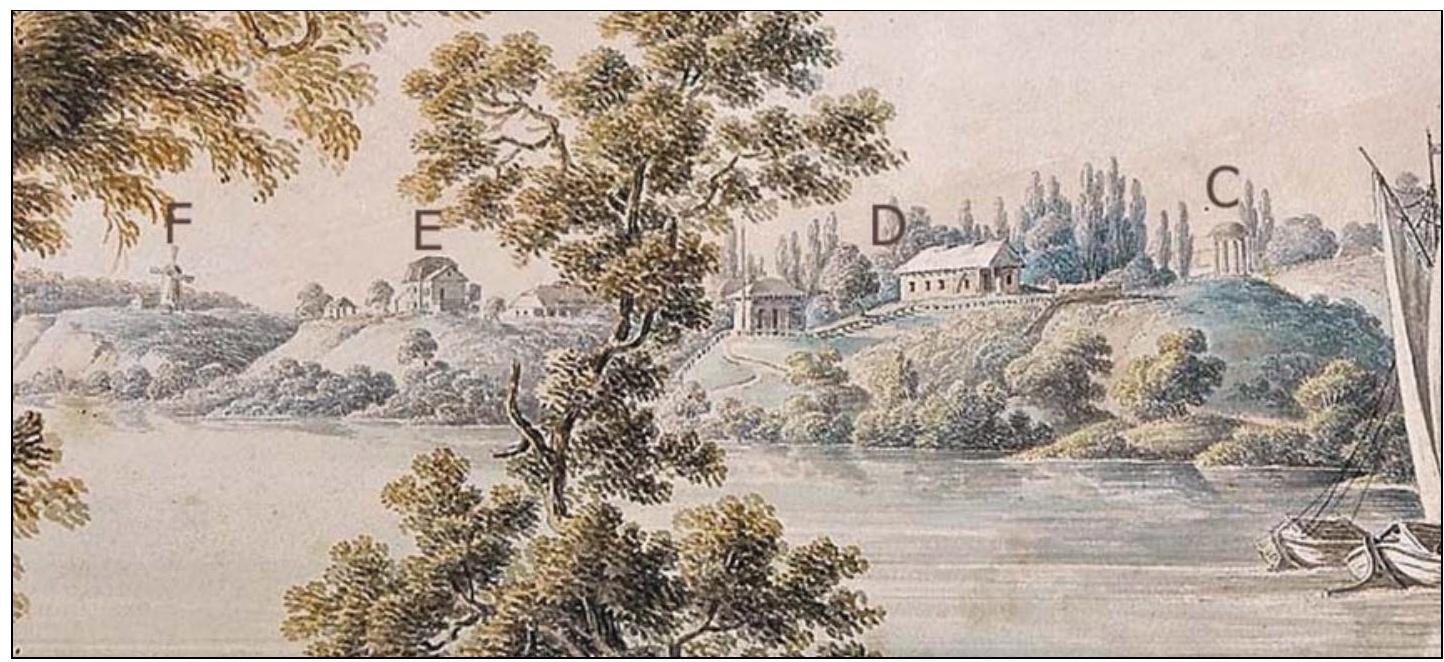

Zmieniła się tylko jego konstrukcja — z płotu drewnianego na pełny mur. Ten ostatni w okresie międzywojennym miał wysokość $1,2 \mathrm{~m}$ i zakończony był dwoma murowanymi słupami ${ }^{125}$. Ozdoby temu przejazdowi przydawały dwie kamienne figury leżących lwów, umieszczone na postumentach naprzeciwko siebie. Rzeźby zadokumentowane na fotografiach np. z lat 1916 i $1942^{126}$ (ryc. 10 i 21) wciąż istnieją, chociaż nie pełnią już swej dotychczasowej roli ${ }^{127}$. Zdjęcia dowodzą także dokonanej w tym czasie przebudowy parkanu. Jego fundamenty odsłonięto w toku badań wykopaliskowych po obu stronach dzisiejszej alei parkowej, płytko pod powierzchnią gruntu (ok. $0,4 \mathrm{~m}$ ). Zbudowane były $\mathrm{z}$ trzech-czterech warstw cegieł łączonych zaprawą, a ich szerokość wynosiła 0,5 m wraz z odsadzkami. Dzięki temu zrekonstruowano szerokość przejazdu, wyznaczanego niegdyś przez figury zwierząt, na 2,8 m (ryc. 15:C-D; ryc. 18:F).

Oprócz wyżej wymienionych budowli w obrębie ogrodu przypałacowego i na wiślanym brzegu rozlokowane były też inne. O większości z nich wiadomo niewiele, z uwagi na skromny zasób źródeł na ich temat. Niektóre, o walorach estetycznych, będące integralnym składnikiem malowniczego pejzażu, uwiecznione zostały na dziewiętnastowiecznych dziełach malarskich.

Wśród nich istotne były p a w i 1 o n y, czyli rozmaite typy niewielkich budowli ogrodowych mających funkcję użytkową, takie jak altany, belwedery, domki ogrodowe i letnie. Często spełniały rolę punktów widokowych lub umieszczone były na zamknięciu osi widokowych, a poprzez swoją stylizację uzupełniały wygląd ogrodu ${ }^{128}$. To miejsca odosobnienia i odpoczynku, które mogły być wybudowane w innym stylu niż główna rezydencja ${ }^{129}$.

Cztery takie obiekty istniały w Młocinach bezsprzecznie na początku XIX w., lecz ich metryka była zapewne osiemnastowieczna. Ich lokalizację i wygląd prezentuje Widok Młocin Zygmunta Vogla z 1803 r. ${ }^{130}$ (ryc. 22:B-D), a jeden z obiektów także Widok dawnej altany

${ }^{125}$ Pape D. 2008, s. 17. Współcześnie w tym miejscu nie ma wyznaczonego przejazdu ani ogrodzenia. Istnieje ogrodzenie tylko wokół całej posesji.

${ }^{126}$ Niektórzy badacze wysuwają przypuszczenia, że figury te pochodzą już z czasu przekształceń założenia według projektu S.B. Zuga. Nie wyjaśniono jednak tej hipotezy, Sokołowska-Grzeszczyk K. 1962, s. 147; Pustoła-Kozłowska E. 1991, s. 8.

${ }^{127} \mathrm{~W}$ roku 2010 figury lwów ustawione były obok siebie na ziemi, bez postumentów, z boku dziedzińca pałacowego.

${ }_{128}$ Böhm A., Zachariasz A. 2005, s. 189-190, hasło: Pavilion.

129 Harrison L. 2011, s. 178.

${ }^{130}$ Vogel Z. 1803. 


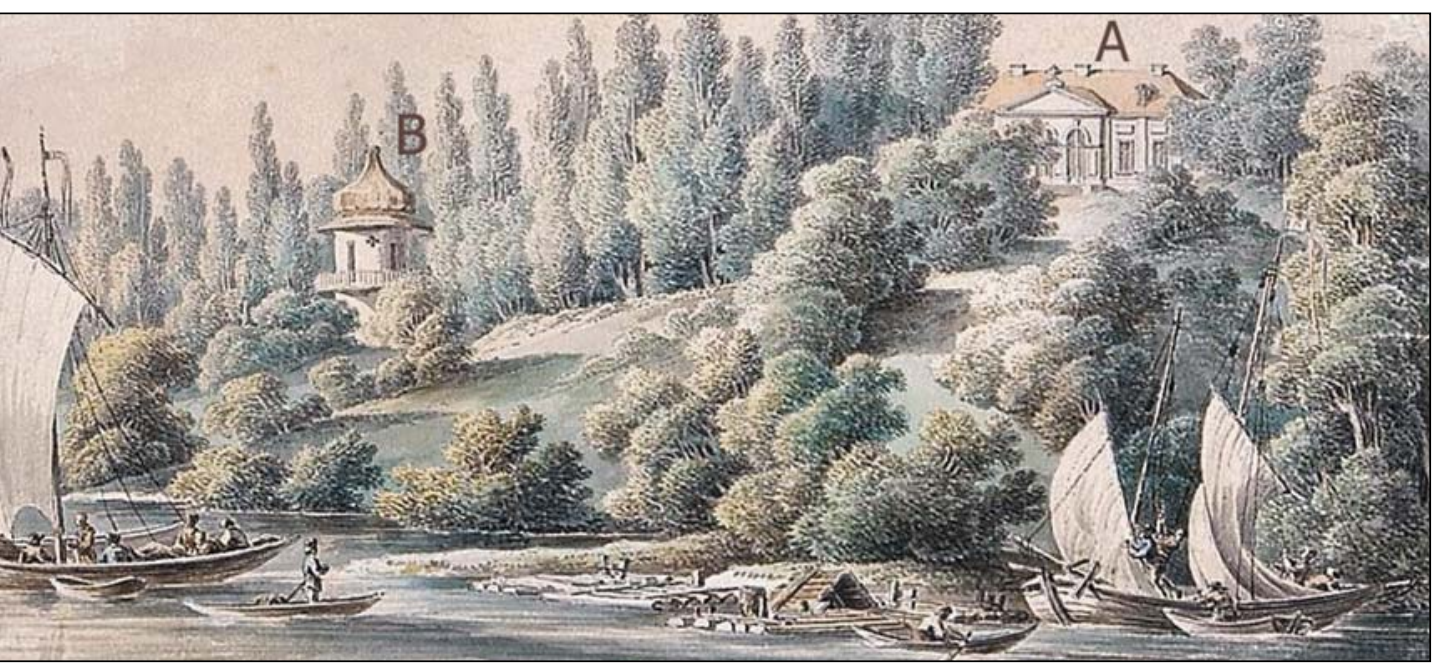

Ryc. 22. Widok Młocin, akwarela Zygmunta Vogla, 1803 r., fragment: A — pałac; B — pawilon orientalny; C - monopter (glorieta); D — ,wiejskie chaty”; E - karczma (austeria); F — wiatrak (w zbiorach Muzeum Narodowego w Warszawie; za: Vogel Z. 1803; oprac. W. Bis)

Fig. 22. A view of Młociny, a watercolour by Zygmunt Vogel, 1803, a fragment: A - the palace; B - the Oriental pavillion; C - the monopteros (gloriette); D - the "peasant cottages"; E - the inn; F - the windmill (the National Museum in Warsaw; after: Vogel Z. 1803; compiled by W. Bis)

w Młocinach, Aleksandra Majerskiego z $1818 \mathrm{r} \cdot{ }^{131}$ Wzniesione zostały w niewielkiej odległości na północny wschód od pałacu, na zboczu nad rzeką. Dwa z nich stanowiły dominanty ${ }^{132}$, wyróżniając się w otaczającym je, roślinnym krajobrazie.

Najbliżej rezydencji położony był wysoki p a w i l o n o r i e n t a ln y, który na akwareli Z. Vogla ma formę walcowatej wieży, w całości tynkowanej, z dachem hełmowym, wąskimi, podłużnymi otworami oraz dookolnym tarasem z barierką (ryc. 22:B). Natomiast na późniejszym rysunku A. Majerskiego budowla ta, która przypuszczalnie mogła mieć ok. 4 m wysokości ${ }^{133}$, wygląda już inaczej. Zmianie uległ kształt dachu na kopulasty z iglicą, dolna partia konstrukcji pozbawiona tynku, z wyeksponowaną kamienną strukturą muru, oraz barierka, której tu brak, a pozostały po niej jedynie poziome belki wystające dookoła bryły. Do transpozycji doszło pomiędzy rokiem 1803 a 1818. Pierwsze dwie cechy to zapewne efekt celowej przebudowy, natomiast ostatnia była raczej skutkiem stopniowej destrukcji. Objaśnia to znakomicie napis na obrazie: „Dawna stara altana dziś zrestaurowana trochę z odmianą”134. Wskazywano, że obiekt przypomina pawilony wschodnie i minarety wznoszone jako elementy architektury stołecznych ogrodów pod koniec XVIII w. ${ }^{135}$ Przy takim założeniu można by go nazwać „kioskiem tureckim”. Niewykluczone, iż zarówno sposób jego budowy, jak i urządzenie wnętrza były przejawem ówczesnej mody na to, co tureckie, a w nawiązaniu do tamtejszych zwyczajów zawierały np. łaźnię bądź miejsce do picia kawy ${ }^{136}$.

${ }^{131}$ Sokołowska A., Zalewska A. 1958, s. 32-33, [ryc.] XIII; Sokołowska-Grzeszczyk K. 1962, s. 142, [ryc.] 12.

132 Por. Harrison L. 2011, s. 205.

${ }^{133}$ Przypuszczenie na podstawie wzrostu postaci przedstawionych na rycinie — dwóch mężczyzn stojących obok budowli.

134 Sokołowska-Grzeszczyk K. 1962, s. 148.

135 Sokołowska-Grzeszczyk K. 1962, s. 148. Pawilony ogrodowe nawiązujące do sztuki Bliskiego Wschodu S.B. Zug zaprojektował np. dla rezydencji na Książęcem, Kwiatkowski M. 1971, s. 371.

${ }_{136}$ O budowlach takich pisał A.F. Moszyński w traktacie z 1774 r., Morawińska A. 1977, s. 63, 113. 
Być może to tę budowlę zaznaczono na rosyjskim planie wydanym w 1860 r., sporządzonym na podstawie pomiarów wykonanych w $1836 \mathrm{r} .{ }^{137}$ (por. ryc. 8). Trudno wobec tego ustalić, które elementy zostały przeniesione na młodszą mapę wprost, a które zaktualizowano. Zaznaczono tu jednak pewien szczegól, pomijany na innych dziewiętnastowiecznych źródłach kartograficznych: okrągły kształt w pobliżu pałacu. Prowadzi do niego aleja z głównego gmachu oraz droga idąca w poprzek głównego duktu. Po integracji tej archiwalnej mapy ze współczesnymi numerycznymi modelami terenu zauważono, uwzględniwszy lekkie przesunięcie na zachód, że okrągły kształt może odpowiadać niewielkiemu wzniesieniu przy współczesnym ogrodzeniu posesji (ryc. 23:2). Wprawdzie taki zarys mógł też mieć np. ogrodowy gazon lub zbiornik wodny, lecz za powyższą hipotezą przemawia porównywalna z obrazem Z. Vogla z 1803 r. odległość pawilonu od pałacu i od brzegu Wisły oraz jego odchylenie na południe względem głównej osi widokowej. Byłby to dowód na przetrwanie reliktów analizowanej budowli.

Drugi to budynek w typie m o n o p t e r $\mathrm{u}^{138}$ - glorieta ${ }^{139}$, nawiązujący do architektury klasycznej, o otwartej konstrukcji w formie okrągłej kolumnady przykrytej kopulastym dachem. Był bardziej odsunięty w stronę wschodnią, znajdował się na szczycie skarpy pomiędzy rezydencją a wąwozem, górował więc nad okolicą (ryc. 22:C). Artysta zapewne posłużył się tu skrótem perspektywicznym, gdyż zobrazował cztery kolumny, w rzeczywistości zaś prawdopodobnie było ich sześćc ${ }^{140}$. Monopter zaprezentowano jedynie na Widoku Młocin i wyczerpuje to zasób przekazów źródłowych odnoszących się do tego obiektu. Miejsce, gdzie był zlokalizowany, jest obecnie zabudowane, co uniemożliwia jego terenowe rozpoznanie. Przypuszczalnie odpowiada tzw. ,świątyni Flory” w teoretycznej wykładni na temat ogrodów A.F. Moszyńskiego: „winna być okrągła, odosobniona, otwarta i stać ma na wzniesieniu” oraz ma mieć „formę rotundy ustawionej na cokole okolonym siedmioma stopniami”"141. Chodziło o uzyskanie odpowiedniego efektu wizualnego: „by jej kopuła z domu właścicieli widzieć się dawała, przyczyni się wtedy do urozmaicenia widoków"142.

$\mathrm{Na}$ wspomnianej akwareli Z. Vogla uwieczniono również dwa inne budynki, stojące obok siebie, wyglądające jak wiejskie chaty, różniące się wielkością i konstrukcją dachu (ryc. 22:D). Oba to obiekty parterowe. Większy z nich był prostokątny, dłuższym bokiem ustawiony równolegle do Wisły. W ścianie tej miał cztery nieduże okna, zaś w widocznej ścianie szczytowej prowadzące do wnętrza wejście. Pokryty był dachem dwuspadowym z dwoma kominami. Prawdopodobnie przynajmniej w części zbudowany został przy użyciu cegieł, na co wskazuje zarys ostrołuku na dłuższej ze ścian. Sąsiedni budynek, usytuowany nieco niżej, bliżej Wisły, był mniejszy, o kształcie zbliżonym do kwadratu, z dachem czterospadowym i jednym kominem, oraz z dwoma wąskimi oknami i wejściem w ścianie skierowanej ku rzece. Na podstawie tego wyobrażenia nie jest jasne, jakiego materiału użyto do pokrycia dachów tych zabudowań. Obok nich znajdował się niski parkan, wiodła ścieżka nad wodę, a łączyły je drewniane schody(?). Przeznaczenie tych budynków jest nieznane. Nasuwają się dwie interpretacje — albo były to

137 Karta okrestnostej Varšavy. 1836-1860.

138 Inaczej monopteros - typ świątyni starożytnej, rozpowszechniony w pawilonach ogrodowych w XVIII i XIX w., Majdecki L. 1981, s. 909; 2007, s. 462, hasło: Monopteros.

139 Glorieta - niewielka budowla ogrodowa w formie otwartego kolumnowego pawilonu, sytuowana w miejscach widocznych, zwykle na wzniesieniach, na zakończeniu osi widokowych, stosowana w ogrodach barokowych XVII i XVIII w. oraz w ogrodach krajobrazowych XVIII i XIX w., Majdecki L. 2007, s. 461, hasło: Glorieta.

${ }^{140}$ Analogicznie wyglądający obiekt zaprojektował S.B. Zug dla Jabłonny w 1783 r., Morawińska A. 1977, [ryc.] 24; por. też Kwiatkowski M. 1971, s. 94, [ryc.] 75.

141 Morawińska A. 1977, s. 96 i 109.

142 Morawińska A. 1977, s. 96. 


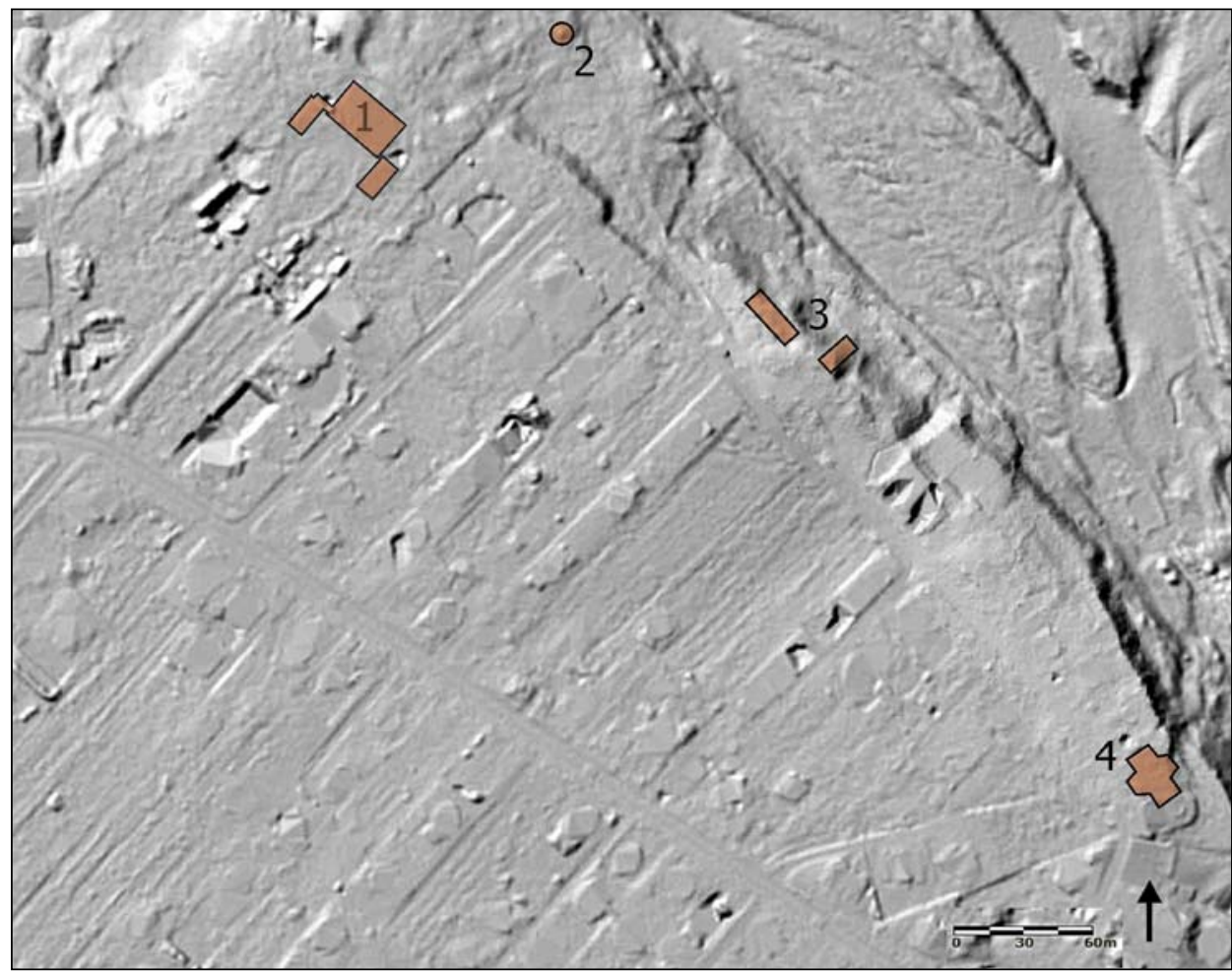

Ryc. 23. Zarys pałacu z oficynami pierwszymi (1), pawilonu orientalnego (2), „wiejskich chat” (3) i karczmy (austerii) (4) w Młocinach ze współczesnej ortofotomapy nałożony na numeryczny model terenu (ISOK-Cieniowanie) (oprac. M. Napieralski, W. Bis)

Fig. 23. The outline of the palace with the outhouses closer to the palace (1), the Oriental pavillion (2), the "peasant cottages" (3) and the inn (4) in Młociny from a contemporary orthophotomap, marked on a numerical model of the area (ISOK-Cieniowanie) (ocompiled by M. Napieralski, W. Bis)

chaty specjalnie zaprojektowane dla służby lub chłopskiej rodziny, albo raczej naśladujące wiejską architekturę stylizowane pawilony, jakie wypełniały kompozycje ogrodów krajobrazowych w stylu angielskim, w tym wokół innych podwarszawskich rezydencji z drugiej połowy XVIII w. ${ }^{143}$ Takie „sielskie”, pozornie prymitywne zabudowania, wyposażone w proste sprzęty, jak chatka rybaka, drwala, pasterza, mieszkanie gajowego, stawiano w celu „zróżnicowania scenerii”144.

Obiekty te to przypuszczalnie dwa prostokątne zarysy prostopadłe względem siebie, widoczne na planie z drugiej połowy XIX w. ${ }^{145}$ Jest to jedyna mapa, na której je zidentyfikowaliśmy. Umiejscowione były niedaleko wiślanego brzegu, na północny zachód od wąwozu. Po nadaniu mapie współrzędnych geograficznych w układzie 1992 stwierdzono, z uwagi na ich

143 Por. Böhm A., Zachariasz A. 2000, s. 31-32, hasło: English landscape gardens. Znane są np. z projektów S.B. Zuga, por. Putkowska J. 2016, s. 284 i n. Podobne rozwiązanie zastosowano np. w Falentach, gdzie zaprojektowano wiejski dom dwurodzinny wzniesiony z kamienia polnego, Kwiatkowski M. 1971, s. 259, [ryc.] 246.

144 Morawińska A. 1977, s. 64, 107.

${ }^{145}$ Mapa okolic Warszawy. 2 poł. XIX w. Można je również dostrzec na Planie szczegółowego zdjęcia części Wisty od wsi Jabłonny do wsi Świder z 1825 r. (Archiwum Główne Akt Dawnych, Zb. Kart. 258-9). 
położenie, że to z dużym prawdopodobieństwem zachowane pod powierzchnią współczesnego gruntu pozostałości owych ,wiejskich” budowli, na obszarze działek katastralnych 139 i 140 (ryc. 23:3).

Z powodu niedostatku źródeł pisanych i ikonograficznych nie wiadomo, jak długo omawiane pawilony istniały. Można jedynie mniemać, iż uatrakcyjniając widok i zapewniając relaks mogły być istotnym elementem architektonicznym założenia także w kolejnych dziesięcioleciach. $\mathrm{O}$ istnieniu którejś z tych budowli, zapewne o pawilonie orientalnym bądź monopterze, wspomniał w swoich felietonach z lat 1816-1821, wydanych zbiorczo w 1828 r., Gerard Maurycy Witowski: „Położenie nad Wisłą romantyczne [...] Widok z altanki pełen wdzięków” ${ }^{446}$. Prócz dwóch wzmiankowanych map topograficznych (z ok. 1850 i z 1860 r.) nie zostały one umieszczone na innych z XIX i z pierwszej połowy XX w. Być może zatem obiekty te przetrwały mniej więcej do połowy XIX stulecia. Na podstawie cech stylowych i podobieństwa do innych pawilonów w ogrodach projektowanych przez Szymona Bogumiła Zuga w epoce stanisławowskiej, np. w Jabłonnie, w Mokotowie, Na Książęcem, autorstwo analizowanych budowli młocińskich również przypisywane jest temu architektowi ${ }^{147}$.

Rodzajem pawilonu, podobnym do owych wiejskich domostw, mogła być także $\mathrm{c} \mathrm{h}$ a t a $\mathrm{r}$ y b a c k a — obiekt nazwany tak przez S.B. Zuga w jego krótkiej wzmiance o Młocinach (z 1784 r.). Na rustykalny charakter budynku wskazywał jego wygląd zewnętrzny: „stara [...] rozwaleniem się grożąca", kontrastujący z okazałym wyposażeniem i przeznaczeniem pomieszczeń, „której wnętrze zawiera piękną łazienkę i kilka pokoi, każdy w inny sposób ozdobiony" 148 . O jego wysokim standardzie świadczył koszt inwestycji podany w przekazie z 1795 r. Friedricha Schlichtegrolla ${ }^{149}$. Obaj autorzy informowali o usytuowaniu budowli na wyspie w nurcie Wisły. Zug sugerował też czas jej funkcjonowania, notując, że zbudowana została „przed kilku laty” za „właściciela teraźniejszego”, którym był wówczas Alojzy Fryderyk Brühl. Kres jej istnienia nastąpił przed datą powstania relacji, na skutek powodzi, „Wylew Wisły zniszczył tę budowlę”, czyli ok. roku 1780. Natomiast funkcję i formę obiektu doprecyzowano w panegiryku wydanym po śmierci hrabiego. To w języku niemieckim eine Eremitage - pustelnia, erem, ermitaż. Terminy te oznaczały pawilony sytuowane na uboczu, przeznaczone do rozmyślań, kontemplacji lub kameralnych przyjęć dworskich. Rozpowszechniły się w architekturze ogrodowej w XVII i XVIII stuleciu ${ }^{150}$. Według niemieckiego autora młociński ermitaż przypominał zrujnowaną świątynię, wewnątrz odpowiednio urządzoną ${ }^{151}$. Architektonicznie nawiązywałby więc do antycznych ruin, które

146 Zbiór ten ukazał się pt. Pustelnik z Krakowskiego Przedmieścia, czyli charaktery ludzi i obyczajów, por. Kalinowska A. b.d.; Sokołowska-Grzeszczyk K. 1962, s. 141.

147 M.in. Sokołowska-Grzeszczyk K. 1962, s. 148; Kwiatkowski M. 1971, s. 83, 85; Kozłowska B. 2005 , s. 7.

148 Podobne chaty, w których przepych wyposażenia zaskakiwał wchodzących zwiedzionych zewnętrzną prostotą, znane są z innych ogrodów z tego czasu, np. z Powązek Izabelli Czartoryskiej, z Siedlec Aleksandry Ogińskiej, Alby Radziwiłłów, Falent, a także z Olesina Potockich (Morawińska A. 1977, s. 65). Wnętrze o podobnym przeznaczeniu to zakamuflowana wśród roślinności „grota z łazienką” w opracowanej przez A.F. Moszyńskiego koncepcji ogrodu. Składała się z pomieszczeń (,gabinetów”) — kuchni do przyrządzania kawy i grzania wody, do zażywania kąpieli oraz „,z łożem dla odpoczynku”; to ostatnie z dekoracją „w guście egipskim”. Wejście prowadziło przez otwór w skale (Morawińska A. 1977, s. 114). Por. np. projekt drewnianej chaty mieszczącej wewnątrz wytworny salon dla założenia w Falentach z ok. 1784 r. (Putkowska J. 2016, s. 508-509, [ryc.] 312).

149 Schlichtegroll F. 1795, s. 43: mehr als 3000 Dukaten.

${ }_{150}$ Majdecki L. 2007, s. 461, hasło: Erem, pustelnia, ermitaż. O jego umiejscowieniu i otoczeniu pisał np. A.F. Moszyński w 1774 r. Ermitaż, zwany przez niego Ustroniem Bramina, powinien „,być wzniesiony w najgęstszym miejscu lasu”, wokół wielkich drzew, strumyka, zagonów warzyw i kwiatów, a jego wnętrza „niechaj będą najskromniejsze", Morawińska A. 1977, s. 94.

151 Schlichtegroll F. 1795, s. 43: Sie glich von aussen einem verfallenen Tempel, und war inwendig zu einem reizenden Aufenthalte eingerichtet. 
miały wywoływać malarską, teatralną wizję starożytności ${ }^{152}$. Taka charakterystyka obiektu z zewnątrz diametralnie różni się od tego, co sugeruje sformułowanie „chata rybacka” użyte przez Zuga. Natomiast w obu relacjach podobnie odnotowano istotę stylizacji budowli. Ponieważ nie dysponujemy ani przedstawieniami tego obiektu, ani innymi źródłami pisanymi, brak podstaw do weryfikacji odmiennych w tej kwestii doniesień.

Aby zlokalizować budynki istniejące niegdyś na wiślanej wyspie a zniszczone przez wezbraną rzekę, oraz rozpoznać te relikty, niezbędne byłoby przeprowadzenie tam klasycznej prospekcji powierzchniowej. Wydaje się to celowe, gdyż na podkładzie „ISOK Cieniowanie” na obszarze kępy rozciągającej się współcześnie wzdłuż Młocin rysują się dwa liniowe obniżenia terenu krzyżujące się niemal pod kątem prostym, które mogą być pozostałościami dawnych ciągów komunikacyjnych.

O istnieniu dwóch kolejnych obiektów - świątyni Diany oraz teatru leśnego donoszą artykuły opublikowane na łamach „Wiadomości Warszawskich” z 31 VIII 1765 r. i „Thornische wochentliche Nachrichten und Anzeigen [...]” z 12 IX 1765 r. To zwięzłe relacje z uroczystości, które odbyły się 27 sierpnia tegoż roku i miały uświetnić pierwszą rocznicę koronacji Stanisława Augusta Poniatowskiego. Ich organizacji podjął się „Jmć Pan Moszyński stolnik koronny” a założenie w Młocinach stało się główną sceną owych wydarzeń. Opis zawiera tylko ogólne informacje o lokalizacji tych obiektów, bez szczegółów o ich konstrukcji oraz charakterze. Ś w i ą ty n i ę D i a ny opisano następująco: „Najjaśniejszemu Panu, który zjechawszy do zwierzyńca w Młocinach zastał obiad zastawiony in Templo Dianae, przy odgłaszaniu się w lesie muzyki tureckiej" ${ }^{153}$. W publikacji w języku niemieckim użyto następującego określenia: dem Tempel der Dianen ahnlichen Pavillon ${ }^{154}$. Obie notki różnią się pod względem umiejscowienia świątyni; w tekście w języku polskim to teren kompleksu leśnego, w wersji niemieckiej zaś wieś. Ta pierwsza wydaje się jednak bardziej prawdopodobna; odpowiadałaby np. teoretycznym zaleceniom w zakresie rozplanowania obiektów ogrodowych wyrażonym przez Augusta Fryderyka Moszyńskiego, będącego organizatorem owych obchodów. Umiejscowienie Templo Dianae przewidywał „pośrodku lasu”, by służyła „podniesieniu i zróżnicowaniu piękności miejsca, w którym krzyżują się drogi”" 155 . Użyty w relacji termin „świątynia Diany" 156 sugeruje obiekt stylizowany na antyczny, nawiązujący formą do klasycznej budowli poświęconej tej rzymskiej bogini i do jej roli jako opiekunki m.in. łowów i świata przyrody. Według Rozprawy o ogrodnictwie angielskim miała być okazała, wzniesiona na planie prostokąta, otoczona portykiem jońskim, z sześciokolumnową fasadą dekorowaną reliefem i posągami, a w jej wnętrzu przewidziano salę teatralną oraz inne pomieszczenia, w tym do picia kawy i foyer dla aktorów ${ }^{157}$.

T e a t r l és n y nadmieniono w dalszej partii tekstu: „Po obiedzie na leśnym theatrum nowej komedii francuskiej J[ego] K[rólewska] M[oś]ć P[an] N[asz] M[iłościwy] przysłuchiwał się” i dalej: „Bóstwa [...] spotkawszy króla zaprowadziły go do theatrum, gdzie alegoryczną

${ }^{152}$ Por. Kwiatkowski M. 1971, s. 363. Znane są projekty S.B. Zuga pawilonów w postaci sztucznych ruin np. z 1780 r. dla rezydencji w Mokotowie (Putkowska J. 2016, s. 378-380, [ryc.] 236-238). A.F. Moszyński proponował w swoim traktacie kilka świątyń, które miały zyskać formę antycznych ruin, w tym Neptuna i Merkurego. Ta pierwsza miała znajdować się na skalistej wyspie, druga zaś — wśród dzikich chaszczy. Wewnątrz nich przewidywano szczątki reliefów, natomiast wokół budowli w pozornym nieładzie fragmenty kapiteli, gzymsów i kolumn (Morawińska A. 1977, s. 57, 115).

153 Wiadomości Warszawskie. 1765, nlb. W cytacie zmodernizowaliśmy pisownię.

154 Thornische wöchentliche Nachrichten. 1765, s. 290.

155 Morawińska A. 1977, s. 96.

156 Identycznie nazwany był np. pawilon zaprojektowany przez S.B. Zuga w ok. 1783 r. dla rezydencji w Jabłonnej (Kwiatkowski M. 1971, s. 94, [ryc.] 75; Putkowska J. 2016, s. 420, [ryc.] 271). Wyglądał on niemal identycznie jak monopteros (glorieta) w Młocinach, przedstawiony na obrazie Z. Vogla z $1803 \mathrm{r}$.

157 Morawińska A. 1977, s. 57, 115-116. 
operę przy wybornych baletach wywiedli śpiewacy włoscy. Po skończonej operze, której sala i wszystkie okolice iluminowane były" ${ }^{158}$. Teatr znajdował się na obszarze zalesionym, którym w przypadku Młocin bez wątpienia był sąsiedni zwierzyniec. Jak można wnioskować z owych zapisów, było to wnętrze urządzone do celów widowiskowych, w którym tego dnia odbyły się prawdopodobnie obydwa spektakle — pierwszy w godzinach wczesnopopołudniowych (z pewnością po dwunastej, gdy Stanisław August przybył do Młocin), drugi zaś wieczorem (po siódmej, gdy rozpoczęto poprzedzającą wystawienie opery inscenizację ataku na wyspę „dzikich ludzi”). Teatr mieścił „salę” odpowiednio oświetloną podczas spektaklu ${ }^{159}$ i niewątpliwie przystosowaną dla zaangażowanych podczas występów aktorów, tancerzy i śpiewaków. Nie wiadomo, jakiego rodzaju była to budowla. Teatry — pełniące swą podstawową funkcję prezentowania rozmaitych sztuk bądź wyłącznie o charakterze dekoracyjnym — nie były ewenementem w europejskich, w tym polskich ogrodach barokowych. Przybierały różne formy architektoniczne, w tym teatrów „zielonych”, gdy ich scenę, kulisy i widownię zazwyczaj amfiteatralną uformowano z drzew i krzewów, ujmowano strzyżonymi szpalerami oraz ozdabiano posągami i fontannami ${ }^{160}$. Taki naturalny teatr wkomponowany w otaczającą zieleń, określony mianem „sielskiego”, opisał np. reżyser młocińskich obchodów w swoim dziele z 1774 r. ${ }^{161}$ Wydaje się prawdopodobne, że wygląd zrealizowanego obiektu w Młocinach mógł być jedną z krajowych inspiracji dla projektu przedstawionego przez A.F. Moszyńskiego.

Tymczasem na podstawie analizowanych, enigmatycznych zapisków nie jest pewne, czy młocińska świątynia Diany i teatr to budowle trwałe, czy jedynie okolicznościowe scenografie - konstrukcje, które wzniesiono tylko na potrzeby wyreżyserowanych, jednodniowych obchodów i wkrótce potem rozebrano. Za pierwszą hipotezą przemawia kilka argumentów. Budowle o nieokreślonym przeznaczeniu istniejące na terenie zwierzyńca zobrazowano na Mappie Młocin z ostatniej ćwierci XVIII w.: cztery czworoboczne, w tym jedna z ryzalitem, skoncentrowane w części południowo-wschodniej, tj. na największej z trzech istniejących tu wysp, oblanej wodą doprowadzoną z kanału ${ }^{162}$ (por. ryc. 3:4, ryc. 24); trzy usytuowane w partii środkowej kompleksu leśnego, na polanie wśród sieci rozplanowanych geometrycznie alejek przecinających się pod kątem prostym lub ok. $45^{\circ}$, jedna zaś w części północnej, przylegająca dłuższym bokiem do ogrodzenia zwierzyńca ${ }^{163}$ (ryc. 3:6). Prawdopodobnie ten ostatni obiekt, położony najbliżej pałacu a zarazem bramy wiodącej od tej strony do zwierzyńca, wymieniono również w inwentarzu z 1765 r. ${ }^{164}$ Nie uściślono jego funkcji, ale wewnątrz miał dwie izby i dwie komory, co wskazywałoby na jego mieszkalno-gospodarcze przeznaczenie. Z kolei S.B. Zug w późniejszych Ogrodach w Warszawie i jej okolicach (z 1784 r.) wyraził eufemistycznie, że tutejszy „Las całkiem oddzielony od bielańskiego jest bardzo miły i kilka budowli go ozdabia"165.

158 W cytacie zmodernizowaliśmy pisownię i interpunkcję, według zasad w: Lepszy K. 1953.

159 Do tego celu używano świec i pochodni bądź — jeżeli było to monumentalne widowisko — płonących beczek ze smołą, Król B. 1955, s. 72-73.

${ }^{160}$ Majdecki L. 2007, s. 465, hasło: Teatr ogrodowy; Böhm A., Zachariasz A. 2017, s. 112, hasło: Theatre. Teatry „zielone” to jeden z trzech rodzajów teatrów na wolnym powietrzu, jakie powstawały w Polsce w XVIII w., obok prowizorycznych — wznoszonych na specjalne okazje i potem rozbieranych, oraz stałych — budowanych w parkach z trwałych materiałów, na wzór antycznych, Król B. 1955, s. 73.

161 Miał być podzielony na dwie części — niżej położoną, amfiteatralną, otoczoną wzniesieniem, którego nierówności tworzyły widownię, oraz scenę, na której krzewy oddzielały orkiestrę, zaś wyniesienie było podium dla aktorów. Nie było kulis, tylko roślinność i naturalne formy terenowe oraz „,chatka w zagłębieniu”, Morawińska A. 1977, s. 70-71, 116.

162 Kanał charakteryzował się trójlistnym zakończeniem na przeciwległym krańcu oraz stawem w połowie długości. Wyspy zaś połączone były mostkami (por. ryc. 3).

163 Por. Putkowska J. 2016, s. 172-173, [ryc.] 111.

164 Inwentarz. 1765, s. 71; Aneks.

165 S.B. Zug 1898, s. 443. 


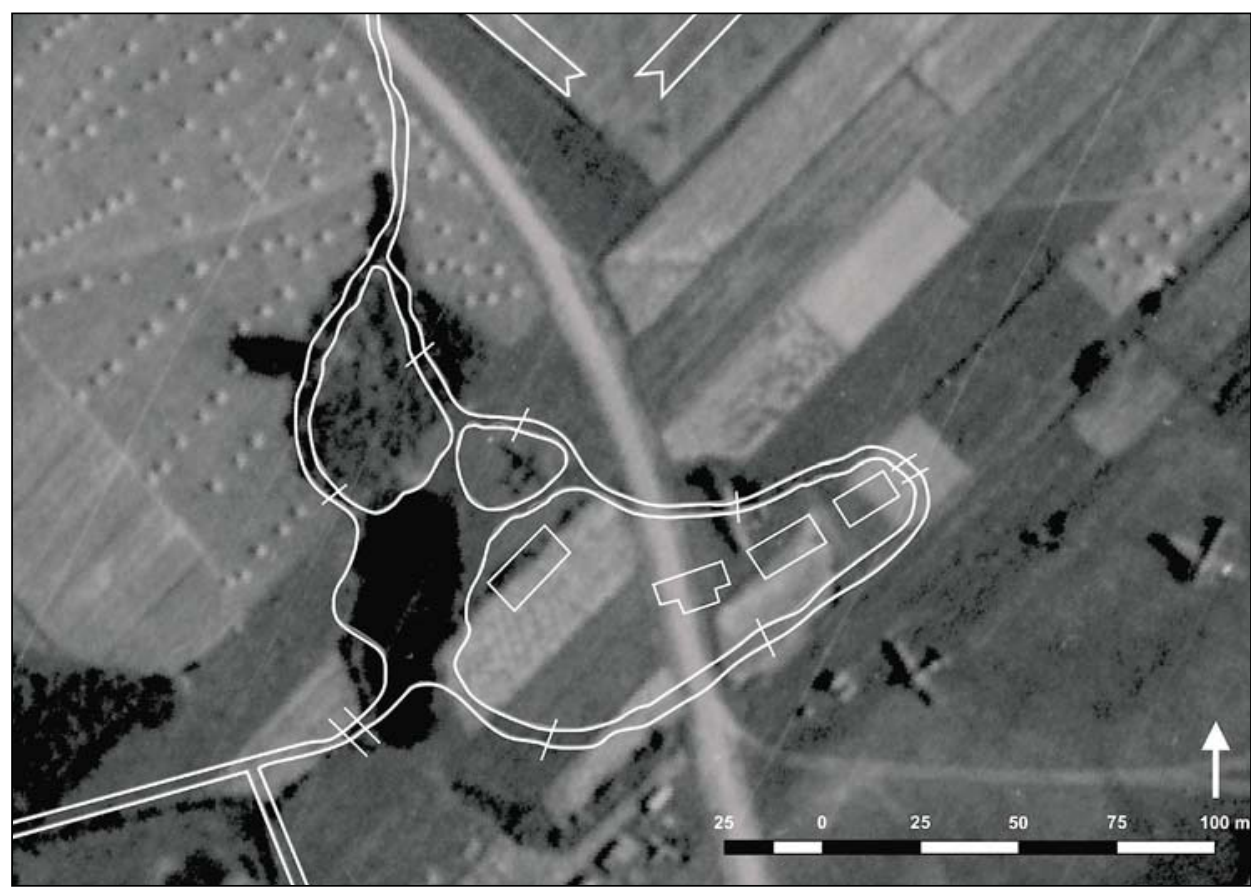

Ryc. 24. Zarys wysp (w tym jednej z zabudowaniami) w zwierzyńcu w Młocinach z Mappy Młocin nałożony na brytyjskie zdjęcie lotnicze z lipca 1944 r. (oprac. M. Napieralski)

Fig. 24. Outlines of the islands (one with buildings) in the game park in Młociny from Mappa Młocin marked on a British aerial photo taken in July 1944 (compiled by M. Napieralski)

Poza tym powstanie teatru w Młocinach nie musiało być uwarunkowane wyłącznie wyżej wspomnianymi niecodziennymi wydarzeniami, ale stanowić mogło wyraz pasji artystycznych właścicieli, zarówno Henryka, jak i Alojzego ${ }^{166}$. Swoista moda na teatry pałacowe i ogrodowe budowane w posiadłościach magnackich ukształtowała się bowiem w Polsce w epoce saskiej pod wpływem dworu królewskiego ${ }^{167}$. W popularyzacji tej sztuki, z racji swych funkcji, sprawującego nadzór nad operą i baletem, uczestniczył także Henryk Brühl ${ }^{168}$. W czasach stanisławowskich zaś jego syn odgrywał w tej dziedzinie różne role, zarówno jako reżyser wielu przedstawień uświetniających oficjalne uroczystości dworskie, aktor, a także autor komedii wystawianych m.in. na warszawskich scenach ${ }^{169}$. Prócz wyżej wymienionych, w Młocinach najpewniej organizowano także inne, choć być może nie tak okazałe widowiska, o czym świadczy np. zachowany projekt dekoracji z 1775 r. autorstwa S.B. Zuga ${ }^{170}$.

Na opracowanym przez pruskich kartografów, prawdopodobnie przez Gustava Johanna Georga von Raucha, planie z ok. 1796 r. ${ }^{171}$ wewnątrz zwierzyńca oznaczonego jako Thiergarten

166 Hniłko A. 1937, s. 16.

167 Zagadnienie teatrów w epoce saskiej ma bogatą literaturę przedmiotu; tu odwołujemy się do przykładowej publikacji — Król B. 1955, s. 70 i n.

168 Dudziak J. 2010, s. 194.

169 Dudziak J. 2010, s. 196-206.

170 Obóz Don Kichota - dekoracja do „fety” urządzonej w Młocinach, 1775 r., rys. ze zbiorów Muzeum Narodowego w Warszawie, Załęski K. 1998, s. 332, [ryc.] 227.

171 Plan von Warschau. ok. 1796. 
uwzględniono m.in. rozległy plac otoczony dziesięcioma budynkami różnej wielkości oraz kanał, ale brak wysp wraz z zabudową (por. ryc. 4). Nie ma po nich śladu również na większości dziewiętnastowiecznych map, zapewne z powodu zagospodarowania terenu zwierzyńca pod nowy folwark ${ }^{172}$.

Obiektami rozlokowanymi w obrębie młocińskiego założenia, głównie o funkcjach utylitarnych, były trzy kolejne. Jeden z nich to b a ż a n c i a r n i a (bażantarnia) - miejsce wydzielone, odpowiednio zagospodarowane i wyposażone w specjalne urządzenia, przeznaczone do hodowli bażantów ${ }^{173}$. To, że istniała w Młocinach, wynika z rejestrów wypłat dla robotników w niej zatrudnionych, w tym dworskiego ogrodnika Thörla, z lat 1752-1757 ${ }^{174}$ i z opisu Ogrodów $w$ Warszawie i jej okolicach z $1784 \mathrm{r} \cdot{ }^{175} \mathrm{Na}$ tej podstawie wiadomo, że znajdowała się w lesie w pobliżu wsi, gdy posiadłość należała do Henryka Brühla, i była „bardzo obszerna”. W momencie spisywania przez architekta informacji była własnością jego syna, „,generała artylerii i hrabiego", lecz prawdopodobnie jej funkcja, pomimo zachowania dawnej nazwy, uległa zmianie, gdyż trzymano tam ,niewielką tylko liczbę sarn”. Z powodu enigmatyczności wzmianki nie dysponujemy innymi precyzyjniejszymi danymi o opisywanym obiekcie. Można jedynie przypuszczać, że bażantarnia miała postać woliery, a założono ją z polecenia saskiego ministra, po przejęciu przez niego młocińskiej posiadłości, co nastąpiło w 1748 r., na potrzeby organizowanych tu polowań. A swą podstawową funkcję mogła przestać pełnić po jego śmierci w roku 1763.

K a r c z m a (austeria) stała „pod górą za ogrodem”176, w sporej odległości od pałacu, przy głównej drodze wsi Młociny ${ }^{177}$, uczęszczanym trakcie komunikacyjnym. Została przedstawiona na kilku obrazach pochodzących z dwóch pierwszych dekad XIX w.: akwareli Zygmunta Vogla, Widok austerii w Młocinach z 1812 r. ${ }^{178}$ (ryc. 25) i na podobnie zatytułowanym rysunku Aleksandra Majerskiego z 1818 r. ${ }^{179}$, które prezentują ją z dwóch różnych stron, a także mniej wyraźnie, gdyż w większym oddaleniu, na innych pracach Vogla - Widoku Młocin z 1803 r., który oddaje jej relację do innych zabudowań przypałacowych (ryc. 22:E), oraz na pejzażu z 1811 r. o tej samej nazwie ${ }^{180}$. Wymienione dzieła ukazują budynek w podobny sposób jako obszerny, drewniany, z jednym piętrem, z dachem dwuspadowym krytym zapewne ceramiczną dachówką, wzniesiony na planie prostokąta, $\mathrm{z}$ ryzalitem $\mathrm{w}$ środkowej części korpusu, gdzie zastosowano dach łamany, co wprowadziło znaczne urozmaicenie bryły. Wejście główne

172 Jedynie na dwóch rosyjskich źródłach kartograficznych — z 1836 r. (Karta okrestnostej Varšavy. 1836-1860, por. ryc. 8) i z drugiej połowy XIX w., opracowanej przez Świątkiewicza (Mapa okolic Warszawy. 2 poł. XIX w.), a szczególnie na drugim, przedstawiono co najmniej jedną wyspę. Na brytyjskim zdjęciu lotniczym z lipca 1944 r. zadokumentowano dwa stawy i wyspę przy północnym brzegu większego z nich (Brytyjskie zdjęcie lotnicze. 1944). Dostrzegalny był też wyróżnik wegetacyjny, tzn. charakterystyczne zmiany w zabarwieniu i rodzajach roślinności, wynikające ze struktury podłoża (por. np. Ławecka D. 2003, s. 59). To ciemniejszy zarys o nerkowatym kształcie, którego kształt odpowiada obniżeniu terenu na podkładzie hipsometrycznym o dynamicznej skali barw ISOK oraz w pewnym stopniu także wyglądowi wyspy z planu Świątkiewicza. Zarys ten różni się od pociągłego kształtu wyspy na planie Gepperta. Różnica ta może wynikać ze zmiany stosunków wodnych w rejonie, spowodowanych melioracją po likwidacji zwierzyńca lub osuszeniem powierzchni pól pod polowe lotnisko założone tu przed drugą wojną światową. Ledwie dostrzegalne relikty fragmentu kanału i jednej z wysp znajdują się przy obecnej ulicy Książąt Mazowieckich, w pobliżu zajezdni Żoliborz (por. Napieralski M. 2017, s. 72-80).

${ }^{173}$ Majdecki L. 2007, s. 459, hasło: Bażantarnia. Z kolei „Ptaszarnię ustawioną na małej polance otoczonej gęstym lasem”, jako składową angielskiej kompozycji ogrodowej wymieniał w swoim traktacie A.F. Moszyński, Morawińska A. 1977, s. 95.

174 Sokołowska-Grzeszczyk K. 1962, s. 144 i przyp. 31; Hentschel W. 1967, t. I, s. 339.

175 Zug S.B. 1898, s. 443.

176 Inwentarz. 1795, s. 70; Aneks.

177 Kwiatkowski M. 1971, s. 83-85.

178 Vogel Z. 1812; Sroczyńska K. 1964, s. 365, [ryc.] 20; Sroczyńska K. 1969, s. 188, nr 263.

179 Sokołowska A., Zalewska A. 1958, s. 32-34, [ryc.] XII; Sokołowska-Grzeszczyk K. 1962, s. 143, [ryc.] 13.

${ }^{180}$ Sroczyńska K. 1969, s. 188, nr 262. 


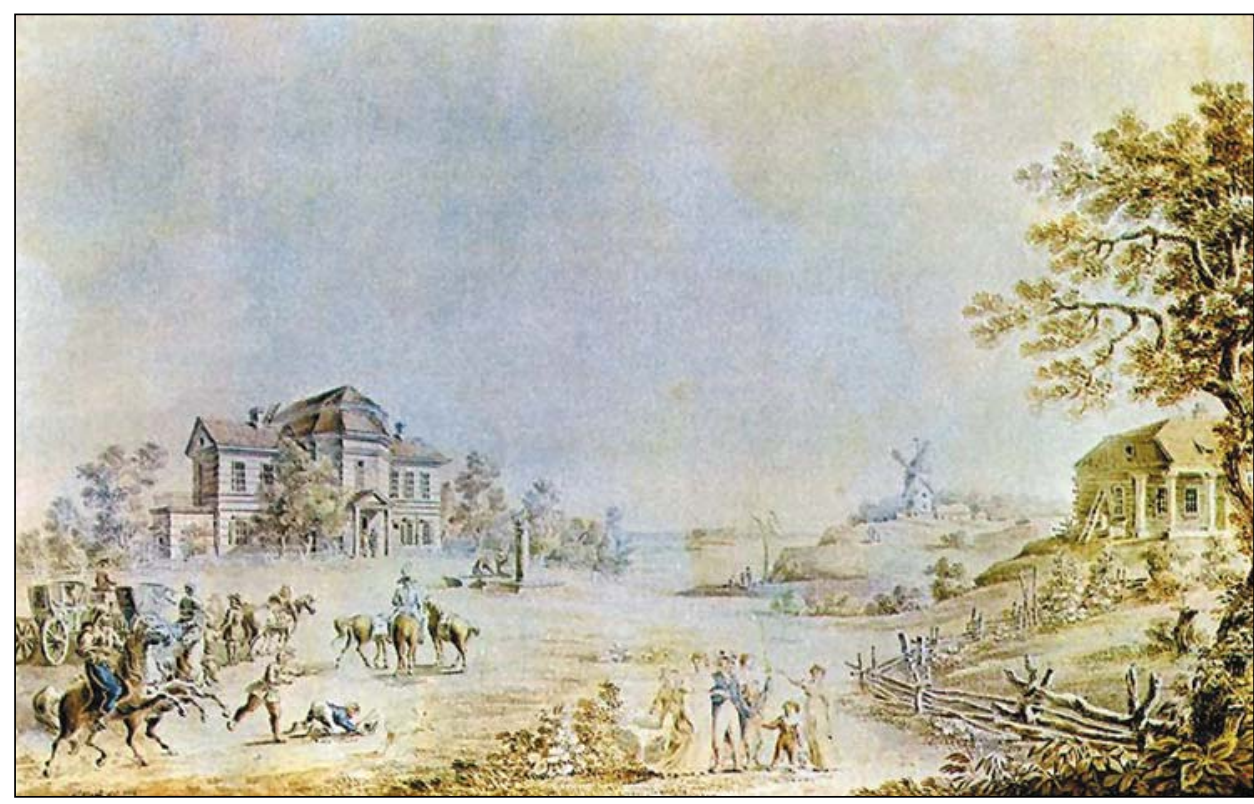

Ryc. 25. Widok austerii w Młocinach, akwarela Zygmunta Vogla, 1812 r.

(w zbiorach Muzeum Narodowego w Warszawie; za: Vogel Z. 1812)

Fig. 25. A view of the inn in Młociny, a watercolour by Zygmunt Vogel, 1812 (the National Museum in Warsaw); after: Vogel Z. 1812)

do budynku, zaopatrzone w ganek, znajdowało się w środkowym ryzalicie fasady. Pomieszczenia na piętrze i na parterze oświetlały podobnej wielkości prostokątne okna. Do szczytowej ściany karczmy przylegał z jednej strony niewielki, czworoboczny budynek parterowy. Wygląd zewnętrzny budowli uzupełnił opis jej wnętrz w inwentarzu dóbr młocińskich z 1765 r. Dokument zawiera też szczegóły odnośnie do techniki budowy oraz niektórych detali trwałego wyposażenia. Stąd wiadomo np. że karczmę wzniesiono w konstrukcji zrębowej (,z drzewa tartego w węgły”), a pokrycie dachowe stanowiły wówczas drewniane elementy (,gontami pobita”). Była ona częściowo podpiwniczona (z „piwnicą murowaną”), na piętro zaś wiodły schody z kuchni. Znajdowało się tu łącznie co najmniej osiem pomieszczeń: sień, dwie izby, w tym jedna określona jako „szynkownia”, gdzie prowadzono wyszynk, dwa alkierze, sala, komórka i piwnica. Budynkiem stojącym przy karczmie była stajnia o konstrukcji „,W słupy”, również $\mathrm{z}$ dachem $\mathrm{z}$ gontów. Przy budynku znajdował się też ogród z miejscem do wypoczynku ${ }^{181}$. Prawdopodobnie na przestrzeni 40-50 lat dzielących oba uwzględnione tu źródła dokonano zmiany pokrycia dachu karczmy — z gontów na dachówkę.

Obiekt ten odnotował także S.B. Zug, który w tekście z 1784 r. nazwał ją „oberżą tutejszą”, tj. w Młocinach leżącą, i podkreślił jako jej walor „,piękny widok”, który „uczynił ją miłą dla mieszkańców miasta przechadzką"182. Zarejestrowano ją również schematycznie na dokumentacji kartograficznej Stanisława Gepperta, z ostatniej ćwierci XVIII w. ${ }^{183}$ (por. ryc. 3:5). To budynek za wsią, ostatni spośród oznaczonych tu zabudowań, najbardziej oddalony na wschód,

181 Inwentarz. 1765, s. 70-71; Aneks.

182 Zug S.B. 1898 , s. 443.

183 Por. Putkowska J. 2016, s. 172-173, [ryc.] 111; por. inne projekty gospód S.B. Zuga, np. dla założeń na Książęcem (ok. 1777 r.) i na Górze (1779 r.), Kwiatkowski M. 1971, s. 56-57, [ryc.] 34, s. 58, [ryc.] 37. 
prostokątny, z dwoma ryzalitami umieszczonymi pośrodku obu dłuższych ścian. Ze względu na dużą dokładność przedstawienia na tej mapie wielu innych szczegółów topograficznych, można z dużym prawdopodobieństwem założyć, że lokalizacja tam austerii najbardziej odpowiada rzeczywistemu jej położeniu. Pod tym względem jest zgodna z umiejscowieniem obiektu na malowniczym ujęciu Młocin z przeciwległego brzegu Wisły z 1803 r. Na współczesnym podkładzie „ISOK Cieniowanie” w pobliżu wschodniego ryzalitu budynku z planu Gepperta zarejestrowano lekkie podwyższenie terenu o prostokątnym kształcie, z dłuższym bokiem równoległym do linii skarpy. Prawdopodobnie jest to zachowany nadal pod powierzchnią gruntu relikt konstrukcji karczmy. Wrysowano go także i zidentyfikowano jako „Kar[czma]” na planie sporządzonym przez Kwatermistrzostwo Generalne Wojska Polskiego w 1819 r. ${ }^{184}$ — na północny wschód od pałacu, w pobliżu drogi, też w formie prostokąta z wyraźnym ryzalitem (por. ryc. 7). Zbliżony obraz prezentuje również mapa z 1829 r. ${ }^{185}$ (por. ryc. 5). Z kolei brak jej już na Planie okrestnostej goroda Varšavy datowanym po roku $1845^{186}$ oraz na Mapie okolic Warszawy z drugiej połowy XIX w. Świątkiewicza ${ }^{187}$. Nie widnieje ona także na żadnym z późniejszych źródeł kartograficznych. Najpewniej nie istniała już w tym czasie. Do jej destrukcji musiałoby zatem dojść najwcześniej w latach trzydziestych XIX stulecia, a okres działania wynosiłby w sumie kilkadziesiąt lat. Dzięki połączeniu Mappy Młocin z planem Environs de Varsovie [Młociny] oraz ortofotomapą i danymi katastralnymi ustalono, że budynek znajdował się na obszarze działek katastralnych nr 147 i 148, przy dzisiejszej ulicy Prozy 20A i 22 (ryc. 23:4).

Najbardziej odsunięty na lewo od północnej fasady młocińskiego pałacu był w i a t r a k, który zamykał ciąg zabudowań na wiślanym brzegu przedstawionych na akwareli Widok Mtocin (ryc. 22:F) To także obiekt z innego, lecz o tej samej nazwie obrazu Z. Vogla z 1811 r. ${ }^{188}$ Dzięki temu można go scharakteryzować jako budynek górujący nad najbliższą okolicą, przypuszczalnie typu holenderskiego, murowany, kryty dachem hełmowym, wyposażony w cztery skrzydła poruszane siłą wiatru, napędzające umieszczone wewnątrz urządzenia. Prawdopodobnie jednak pełnił głównie funkcję dekoracyjną, gdyż ,ustawiony tu na brzegu rzeki, przynosi[ł] piękny widok"189. Wiatrak ten nie został uwzględniony w żadnej ze znanych pisanych relacji. Zaznaczono go natomiast na niektórych materiałach kartograficznych, w tym z roku 1819 i 1829 (por. ryc. 5 i 7). Trudno stwierdzić, jak długo funkcjonował. Był zapewne jeszcze inwestycją brühlowską.

Podsumowując, opisane powyżej różnorodne zabudowania były integralnymi elementami wieloczłonowego zespołu rezydencjonalnego w Młocinach i pełniły w nim wielorakie funkcje. Z tym też wiązał się ich zróżnicowany charakter i postać. W większości przypadków, o ile to można ustalić na podstawie uwzględnionych źródeł, ich forma podporządkowana była zrealizowanej konsekwentnie, spójnej wizji architektonicznej, zgodnej z obowiązującymi trendami w aranżacji przestrzeni założeń pałacowo-ogrodowych. Główny kształt nadali mu architekci działający dla obu Brühlów — Johann Friedrich Knöbel i Szymon Bogumił Zug, których dzieło w głównych zrębach przetrwało niespełna stulecie. Szczególne zasługi poczynił tu drugi z planistów, którego efektowną wizję artystyczną, jak się zdaje, w pełni tu wykonano. Zawierała

\footnotetext{
184 Environs de Varsovie [Młociny]. 1819.

185 Plan okolic Warszawy. 1829.

186 Plan okrestnostej goroda Varšavy. po 1845.

187 Mapa okolic Warszawy. 2 poł XIX w.

188 Sroczyńska K. 1969, s. 188, nr 262.

189 Tak podstawową rolę wiatraka wśród innych budowli ogrodowych określił planista, A.F. Moszyński w 1774 r., a to — jak się wydaje — odpowiadało realiom młocińskim, Morawińska A. 1977, s. 113.
} 
charakterystyczne dla jego twórczości eklektyczne rozwiązania, spajające cechy wielu wpływów kulturowych, tj. zapożyczeń z antyku, motywów bliskowschodnich, oddziaływań wzorów angielskich, nawiązań do architektury wiejskiej i motywów naturalistycznych ${ }^{190}$. Jest prawdopodobne, że przy ich realizacji czerpał obficie z pomysłów Augusta Fryderyka Moszyńskiego, którego projekt ogrodu angielskiego z 1774 r. zilustrował ${ }^{191}$. Te z kolei nie były koncepcjami oryginalnymi, lecz zaczerpniętymi głównie z osiemnastowiecznych wzorów angielskich i francuskich. Te liczne elementy włączono w otaczający krajobraz, którego podstawowymi składnikami oraz walorami były zieleń i woda, zarówno te naturalne, jak i skomponowane zgodnie z wytycznymi osiemnastowiecznej sztuki ogrodowej. Założenie młocińskie niewątpliwie w mniejszej skali, lecz całokształtem koncepcji i jej detalami można porównać do innych projektowanych $\mathrm{z}$ rozmachem stołecznych i podwarszawskich rezydencji magnackich tego czasu.

Do najstarszych zabudowań powstałych w Młocinach za Henryka Brühla ok. 1748-1763 r., będących wynikiem prac Johanna Friedricha Knöbla, należały towarzyszące pałacowi trzy drewniane oficyny i murowana kuchnia, prawdopodobnie pergola na dziedzińcu, sąsiedni folwark, być może wraz z cegielnią, masywna brama od południa, zwierzyniec z bażantarnią, teatr leśny i świątynia Diany. Za kolejnego właściciela, Alojzego Fryderyka, który zatrudnił tu Szymona Bogumiła Zuga, w latach ok. 1772-1784 wzniesiono zapewne większość ozdobnych pawilonów nad rzeką oraz inne użytkowe budynki, także nadając im odpowiedni wygląd. Były to murowane oficyny, towarzyszące im małe budynki zapewne gospodarcze, nowa brama na końcu alei grabowej, pawilon orientalny, monopter, dwie wiejskie chaty, chata rybacka vel ermitaż, karczma i wiatrak. Te ogrodowe budowle nie przetrwały w większości dłużej niż do ok. połowy XIX w. Do znacznej przebudowy założenia i odtworzenia niektórych jego osiemnastowiecznych elementów doszło najpewniej na początku XX w., gdy pałac i jego najbliższe otoczenie przejął Stefan Kazimierz Grodzicki. Odbudowano wówczas oficyny, powiększając ich powierzchnię użytkową, oraz małe, sąsiadujące z nimi budynki przekształcone wtedy na mieszkalne i częściowo palisady — pergole. Wzniesiono także inne obiekty — cieplarnię, stajnię i oborę oraz zmodernizowano ogrodzenie z przejazdem na dziedziniec.

Dzięki badaniom wykopaliskowym przeprowadzonym w obrębie dzisiejszej posesji na południe od pałacu odsłonięto relikty budowli niezachowanych na powierzchni gruntu: oficyn drugich, sąsiadujących z nimi budynków gospodarczych i mieszkalnych, palisad — pergoli, bram i przejazdu. Na podstawie analizy przedstawionych źródeł ustalono w przybliżeniu lokalizację osiemnastowiecznych zabudowań folwarcznych i cegielni. Porównawszy akwarelę Zygmunta Vogla Widok Młocin z treścią map opracowanych w XIX w. określono obszar, na którym mogą zalegać pozostałości kolejnych budowli widniejących na obrazie, a dziś nieistniejących, tj. karczmy (austerii) i pawilonu orientalnego. Dokładna obserwacja archiwalnych źródeł kartograficznych, a następnie ich integracja z podkładami numerycznego modelu terenu pozwoliła też na zidentyfikowanie pozostałości dwóch wysp na terenie zwierzyńca młocińskiego ${ }^{192}$, z których jedna w drugiej połowie XVIII w. była zabudowana. Podjęcie dalszych prac wykopaliskowych i zastosowanie metod geofizycznych umożliwiłoby potwierdzenie dokonanych obserwacji.

Od drugiej wojny światowej omawiane założenie młocińskie, mimo prób remontu pałacu oraz projektów rewaloryzacji parku, nie odzyskało dawnej świetności. Jak na razie nie widać też szansy, by stało się to w najbliższym czasie. Ze względu na zagrożenie destrukcją tego obszaru na skutek współczesnej zabudowy mieszkaniowej i infrastrukturalnej konieczne

190 Por. Kwiatkowski M. 1971, s. 353-378.

191 Morawińska A. 1977, s. 78-79.

192 Relikty te zajmują obecnie powierzchnię niespełna 1,2 ha, co stanowi niewielki procent obszaru dawnego parku, obejmującego pod koniec XVIII w. 42,5 ha - obliczenia M. Napieralskiego, przy użyciu programu QuantumGIS, na podstawie Mappy Młocin Stanisława Gepperta z ostatniej ćwierci XVIII w. (por. Napieralski M. 2017). 
wydaje się wprowadzenie wytypowanych powyżej rejonów, gdzie zarejestrowano omawiane obiekty, do bazy Archeologicznego Zdjęcia Polski jako nowożytnych stanowisk archeologicznych, w przyszłości zaś zadbanie przynajmniej o właściwy nadzór archeologiczny w tych miejscach.

Adresy Autorów:

dr Magdalena Bis

Instytut Archeologii i Etnologii PAN

Al. Solidarności 105

00-140 Warszawa

magdabis@wp.pl

ORCID: 0000-0002-0108-7625

mgr Wojciech Bis

Instytut Archeologii i Etnologii PAN

Al. Solidarności 105

00-140 Warszawa

wojtekbis@wp.pl

ORCID: 0000-0003-1142-408X

mgr Mateusz Napieralski

Wojskowe Centrum Edukacji Obywatelskiej

ul. Nieświeska 54/56 (budynek 35)

03-867 Warszawa

mateusz.t.napieralski@gmail.com

ORCID: 0000-0002-8690-4283

\section{BIBLIOGRAFIA}

\section{Źródła}

Brytyjskie zdjęcie lotnicze. 1944. Młociny 26 lipca 1944 r., brytyjskie zdjęcie lotnicze ze zbiorów brytyjskiego archiwum SPP, za: Zieliński J. 2016, s. 212; http://bielany.waw.pl//data/other/ bielany_przewodnik_historyczny_ix_2016_.pdf (dostęp 20.03.2019 r.).

Environs de Varsovie [Młociny]. 1819. Environs de Varsovie [Młociny], oprac. Kwatermistrzostwo Generalne, wyd. 3 (1820), Warszawa, za: Jankiewicz A. i in. 1999, s. 62, 66-67; https://polona.pl/ item/environs-de-varsovie-mlociny,ODc5NzM4OA/0/\#info:metadata (dostęp 18.03.2019 r.).

Inwentarz. 1765. Inwentarz wsi Młocin w województwie mazowiedzkim ziemi warszawskiey leżacey [...] zalecony dnia ósmego marca roku 1765 [...] spisany, Archiwum Główne Akt Dawnych w Warszawie, Zespół 1/7/10, Seria 11 Archiwum Skarbu Koronnego LVI, Inwentarze Starostw, jednostka 304, s. 67-71, nr mikr. 2915.

Karta okrestnostej Varšavy. 1836-1860. Karta okrestnostej Varšavy sniata instrumentalno v 1836, ispravliena głazomierno v 1860 godu; http://maps.mapywig.org/m/City_plans/Central_Europe/ KARTA_OKRESTNOSTEJ_VARSHAVY_6_18,800K_1836-1860.jpg (dostęp 18.03.2019 r.).

Karta Varšavskogo Učastka. 1875. Karta Varšavskogo Učastka, tzw. Kiriczenki, za: Zieliński A. 2016, s. 173; http://bielany.waw.pl//data/other/bielany_przewodnik_historyczny_ix_2016_.pdf (dostęp 20.03.2019 r.); Archiwum Państwowe w Warszawie, Kolekcja I planów i map Warszawy, sygn. 231.

Mapa okolic Warszawy. 2 poł. XIX w. Mapa okolic Warszawy, oprac. Świątkiewicz, za: Bartoszewicz A., Bartoszewicz H. 2002, s. 185, nr 639. 
Mappa Młocin. 4 ćw. XVIII w. Mappa Młocin, rys. Stanisław Geppert, zbiory on-line Gabinetu Rycin Uniwersytetu Warszawskiego; http://egr.buw.uw.edu.pl/sites/default/files/imagecache/resize_ cooliris/artworks/4000/4253/8995.jpg (dostęp 20.03.2019 r.).

Muzealna. 1976-1977. Muzealna, zdjęcie lotnicze, 1976-1977, Urząd m. st. Warszawy, Historyczne granice miasta, ulica/adres Muzealna, mapa.um.warszawa.pl/mapaApp1/mapa?service=mapa historyczna (dostęp 16.03.2019 r.).

Muzealna. 1982. Muzealna, zdjęcie lotnicze, 1982, Urząd m. st. Warszawy, Historyczne granice miasta, ulice/adres Muzealna, mapa.um.warszawa.pl/mapaApp1/mapa?service=mapa historyczna (dostęp 16.03.2019 r.).

Muzealna. 1987. Muzealna, zdjęcie lotnicze, 1987, Urząd m. st. Warszawy, Historyczne granice miasta, ulice/adres Muzealna, mapa.um.warszawa.pl/mapaApp1/mapa?service=mapa_historyczna (dostęp 16.03.2019 r.).

Muzealna. 2011. Muzealna, zdjęcie lotnicze, 2011, Urząd m. st. Warszawy, Historyczne granice miasta, ulice/adres Muzealna, mapa.um.warszawa.pl/mapaApp1/mapa?service=mapa_historyczna (dostęp 16.03.2019 r.).

Okolice Warszawy w diametrze piaciu mil. 1783. Okolice Warszawy w diametrze piaciu mil, oprac. H.K. de Perthées, ryt. P. Tardieu (1794), za: Gromski J. 1997, s. 270, [ryc.] 2; Jankiewicz A. i in. 1999, s. 44-45.

Plan miasta stolecznego Warszawy i okolic. 1931. Plan miasta stotecznego Warszawy i okolic, oprac. Magistrat Miasta Stołecznego Warszawy, Wydział Techniczny, Dział Regulacji i Pomiarów, Warszawa, https://polona.pl/item/plan-miasta-stolecznego-warszawy-i-okolic,Mzc0MTYxMQ/ \#info:metadata (dostęp 18.03.2019 r.).

Plan okolic Warszawy. 1829. Plan okolic Warszawy. Plan des environs de Varsovie, oprac. T. Polakiewicz, Kwatermistrzostwo Generalne, Warszawa, za: Jankiewicz A. i in. 1999, s. 68-69; https://polona.pl/item/plan-okolic-warszawy-plan-des-environs-de-varsovie,ODc5NzM2Mw/ \#info:metadata (dostęp 18.03.2019 r.).

Plan okrestnostej goroda Varšavy. po 1845. Plan okrestnostej goroda Varšavy, oprac. Voenno-Topografičeskij Otdiel Glavnogo Štaba (Armia Carska), Petersburg, https://polona.pl/item/ plan-okrestnostej-goroda-varsavy,ODc5NzM2MQ/0/\#info:metadata (dostęp 18.03.2019 r.).

Plan von Warschau. ok. 1796. Plan von Warschau und Prag nebst umliegender Gegend, oprac. G. von Rauch, za: Gromski J. 1997, s. 269, [ryc.] 1; Jankiewicz A. i in. 1999, s. 48-49; Weszpiński P. 2007, s. 58; Archiwum Główne Akt Dawnych, Zbiór Kartograficzny, sygn. 86-19.

Planta miasta Warszawy. 1777. Planta miasta Warszawy z okolicami, oprac. M. Deutsch, za: Jankiewicz A. i in. 1999, s. 36-37.

Schlichtegroll Friedrich. 1795. Nekrolog auf das Jahr 1793 enthaltend Nachrichten von dem Leben merkwürdiger in diesem Jahre verstorbener Personen, t. 2, Gotha (hasło: Den 31. Jan. 1793 starb zu Berlin Friedr. Aloysius RsGraf von Brühl, s. 24-66, o Młocinach: s. 43-44).

Sonderplan. 1915. Sonderplan Nowogeorgijewsk-Segrshe-Warschau, za: Królikowski L., Szaniawska L. 1999 , s. 26.

Szkurłat Maria. 2009. Katalog planów, pomiarów i rysunków architektonicznych w zbiorach Instytutu Sztuki PAN, t. II: Warszawa, cz. 1, red. W. Mossakowska, Warszawa.

Vogel Zygmunt. 1803. Widok Młocin, akwarela, w zbiorach Muzeum Narodowego w Warszawie, http://cyfrowe.mnw.art.pl/dmuseion/docmetadata?id=19308\&show_nav=true (dostęp 21.03. 2019 r.).

Vogel Zygmunt. 1812. Widok austerii w Młocinach, akwarela, w zbiorach Muzeum Narodowego w Warszawie, http://www.pinakoteka.zascianek.pl/Vogel/Images/Mlociny_austeria.jpg (dostęp 21.03.2019 r.).

Warschau Zoliborz. 1940. Topographische Karte:25 000. Vorläufige Ausgabe. 3932 G Warschau Zoliborz, oprac. Raichsamt für Landesaufnahme, b.m., http://maps.mapywig.org/m/WIG maps/ series/025K_german/3932_G_Warschau_Zoliborz_1940_LoC_G6520_s25_.G4.jpg (dostęp 10.03.2019 r.). 
Warszawa-Żoliborz. 1936. PAS 39 - SŁUP $32-$ - W Warszawa-Żoliborz, Warszawa, http://maps. mapywig.org/m/WIG_maps/series/025K/P39-S32-G_WARSZAWA-ZOLIBORZ_1936_LoC_ G6520_s25_.P6.jpg (-̄ostęp 18.03.2019 r.).

Thornische wöchentliche Nachrichten. 1765. Thornische wöchentliche Nachrichten und Anzeigen nebst einem Anhange von gelehrten Sachen, nr 37, 12 IX, s. 290-292.

Wiadomości Warszawskie. 1765. „Wiadomości Warszawskie”, nr 67, 31 VIII, nlb.

Zug Szymon Bogumił. 1898. Ogrody w Warszawie i jej okolicach, opisane w roku 1784, „, Kuryer Niedzielny”, R. II, nr 28, 28 VI (10 VII), s. 443-444.

\section{Opracowania}

Bartoszewicz Agnieszka, Bartoszewicz Henryk. 2002. Plany szczegółowe Warszawy 1800-1914 w zbiorach Archiwum Głównego Akt Dawnych: katalog, Warszawa-Kielce.

Bis Magdalena, Bis Wojciech. 2011-2012. Założenie pałacowo-parkowe Brühla na Młocinach - wyniki badań archeologicznych w 2010 r., „Z Otchłani Wieków”, R. 66, nr 1-4 (Archeologia Warszawy), s. 91-99.

Bis Wojciech. 2010. „Sprawozdanie z badań archeologicznych na terenie założenia pałacowo-parkowego Brühla, Warszawa-Młociny, ul. Muzealna 1", Warszawa (maszynopis w archiwum Stołecznego Konserwatora Zabytków).

Böhm Aleksander, Zachariasz Agata. 2005. Architektura krajobrazu i sztuka ogrodowa. Ilustrowany stownik angielsko-polski, [t.] $k-q$, Warszawa.

Böhm Aleksander, Zachariasz Agata. 2017. Architektura krajobrazu i sztuka ogrodowa. Ilustrowany stownik angielsko-polski, [t.] $r-z$, Warszawa.

Bukar Seweryn. 1912. Pamiętniki z końca XVIII i początków wieku XIX, Warszawa.

Carosi Jean Philippe de. 1777. Essai d'une lithographie de Mlocin, écrit à Varsovie en 1777, Dresden.

Chlebowski Bronisław. 1885. Hasło: Młociny, [w:] Słownik Geograficzny Królestwa Polskiego i innych krajów słowiańskich, red. B. Chlebowski, W. Walewski, t. VI, Warszawa, s. 531-532.

Chrościcki Juliusz A., Rottermund Andrzej. 1977. Atlas architektury Warszawy, Warszawa (hasło: Ulica Muzealna, s. 96).

Dix Brian. 2016. Wykorzystanie archeologii w konserwacji zabytkowych parków i ogrodów / Using archaeology in the conservation of historic parks and gardens, „Ochrona Zabytków”, t. 69, nr 1 (Ogrody historyczne: utrzymanie, konserwacja i restauracja / Historic gardens: maintenance, conservation and restoration), s. 93-103.

Dudziak Juliusz. 2010. Alojzy Fryderyk von Brühl (1739-1793), Zielona Góra.

Encyklopedia Warszawy. 1975. Encyklopedia Warszawy, red. S. Herbst i in., Warszawa (hasło: Mtociny, s. 388).

Gołembnik Andrzej. 2015. Podstawy metodyczne badań archeologicznych zespołów pałacowo-ogrodowych na przykładzie rezydencji w Wilanowie i Łazienkach Królewskich, [w:] Renovatio et restitutio: materiały do badań i ochrony założeń rezydencjonalnych i obronnych, red. P. Lasek, P. Sypczuk, Warszawa, s. 9-26.

Gromski Jerzy. 1997. Plany Warszawy i mapy okolic Warszawy w zbiorach Muzeum Historycznego m. st. Warszawy, „Almanach Muzealny”, t. 1, s. 263-294.

Harrison Lorrain. 2011. Jak czytać ogrody? Krótki kurs historii ogrodów, Warszawa.

Hass Ludwik. 1982. Poths (Potz) Jerzy Fryderyk, [w:] Polski Stownik Biograficzny, t. XXVII/1, z. 112, Wrocław, s. 718.

Hentschel Walter. 1967. Die sächsische Baukunst des 18. Jahrhunderts in Polen, t. I-II, Berlin.

Hniłko Antoni. 1937. Brühl Alojzy Fryderyk Józef, [w:] Polski Słownik Biograficzny, t. III, Kraków, s. $13-16$.

Jankiewicz Adam, Weszpiński Paweł E., Witecki Marek. 1999. Atlas historyczny Warszawy: wybrane źródta kartograficzne, Warszawa. 
Kalinowska Anna. brak daty. Pustelnik z Krakowskiego Przedmieścia, [w:] Silva Rerum. Pasaż wiedzy Muzeum Pałacu króla Jana III w Wilanowie; https://www.wilanow-palac.pl/pustelnik z_krakowskiego_przedmiescia.html (dostęp 25.03.2019 r.)

Katalog rysunków. 1967. Katalog rysunków z Gabinetu Rycin Biblioteki Uniwersyteckiej w Warszawie. $C z$. 1. Varsaviana. Rysunki architektoniczne, dekoracyjne, plany $i$ widoki z XVIII $i$ XIX wieku, oprac. T. Sulerzyska, S. Sawicka, przy udziale J. Trenklerówny, Warszawa.

Konopczyński Władysław. 1937. Brühl (von) Henryk, [w:] Polski Stownik Biograficzny, t. III, Kraków, s. $16-19$.

Korotyński Władysław. 1918. Młociny, „Tygodnik Ilustrowany”, nr 19 (11 maja), s. 222-224.

Kozłowska Barbara. 2005. „Skrócone studium rozwoju przestrzennego założenia parkowo-pałacowego w Młocinach", Warszawa (maszynopis w archiwum S. Gardockiego).

Król Barbara. 1955. Teatry na wolnym powietrzu w Polsce w XVIII wieku, „Pamiętnik Teatralny”, z. 2, s. 69-100.

Królikowski Lech, Szaniawska Lucyna. 1999. Plany i mapy Warszawy 1831-1944, Warszawa.

Kwiatkowski Marek. 1971. Szymon Bogumit Zug. Architekt polskiego Oświecenia, Warszawa.

Lepszy Kazimierz. 1953. Instrukcja wydawnicza dla źródel historycznych od XVI w. do pot. XIX w., Warszawa.

Libicki Piotr, Libicki Marcin. 2009. Dwory i pałace wiejskie na Mazowszu, Poznań (hasło: Warszawa-Młociny, s. 462-464).

Ławecka Dorota. 2003. Wstęp do archeologii, Warszawa-Kraków.

Majdecki Longin. 1973. Ogrody warszawskie w XVIII wieku, [w:] Warszawa XVIII wieku, z. 2, red. J. Kowecki, Warszawa, s. 219-257.

Majdecki Longin. 1981. Historia ogrodów. Przemiany formy i konserwacja, Warszawa.

Majdecki Longin. 2007. Historia ogrodów, t. 1: Od starożytności po barok, Warszawa.

Mały słownik. 1974. Mały słownik języka polskiego, red. S. Skorupko, H. Auderska, Z. Łempicka, Warszawa.

Maślanka Mateusz, Wężyk Piotr. 2015. Projekt ISOK — geneza i cel realizacji, [w:] Podręcznik dla uczestników szkoleń z wykorzystania produktów LiDAR, GUGiK, red. P. Wężyk, Warszawa, s. $12-21$.

Mączyński Ryszard. 2016. Zug (Cug, Zuck, Zugh, Zugk) Simon (Szymon) Gottlieb (Bogumit), [w:] Słownik architektów i budowniczych środowiska warszawskiego XV-XVIII wieku, red. P. Migasiewicz, H. Osiecka-Samsonowicz, J. Sito, Warszawa, s. 498-509.

Morawińska Agnieszka. 1977. Augusta Moszyńskiego Rozprawa o ogrodnictwie angielskim 1774, Wrocław.

Napieralski Mateusz. 2017. „Założenie pałacowo-parkowe von Brühla na Młocinach. Próba rekonstrukcji z zastosowaniem metod nieinwazyjnych", Warszawa (maszynopis pracy magisterskiej, w archiwum IA UW).

Ogród. 1998. Ogród. Forma - symbol - marzenie, red. M. Szafrańska, Warszawa.

Olbrzymi pożar. 1934. Olbrzymi pożar w pałacu w Młocinach, „5-ta Rano: bezpartyjny dziennik żydowski”, R. 4, nr 135 (16.05), s. 3.

Pape Dorota. 2008. „Analizy historyczne dla założenia pałacowo-parkowego w Młocinach”, Warszawa (maszynopis w archiwum S. Gardockiego).

Pevsner Nicolaus, Fleming John, Honour Hugh. 1992. Encyklopedia architektury, przeł. A. Dulewicz, Warszawa.

Pustoła-Kozłowska Ewa. 1991. „Warszawa-Młociny, Zespół pałacowo-ogrodowy. Skrócone studium historyczne wraz z wytycznymi konserwatorskimi do projektu ośrodka konferencyjnego Instytutu Matematyki PAN", Warszawa (maszynopis w archiwum S. Gardockiego).

Pustoła-Kozłowska Ewa, Konopka Marek, Pacuski Kazimierz, Urbaniak Pola. 2005. Dawne Łomianki. Historia, ludzie, zabytki, Łomianki. 
Putkowska Jolanta. 2016. Warszawskie rezydencje na przedmieściach i pod miastem $w$ XVI-XVIII wieku, Warszawa.

Sito Jakub. 2016. Knöbel Johann Friedrich, [w:] Słownik architektów i budowniczych środowiska warszawskiego $X V-X V I I I$ wieku, red. P. Migasiewicz, H. Osiecka-Samsonowicz, J. Sito, Warszawa, s. 259-262.

Siuder Henryk. 1974. „Warszawa-Młociny: zespół pałacowy — badania architektoniczne”, Warszawa (maszynopis, w Archiwum NID oddział w Grodzisku Mazowieckim).

Słownik Polszczyzny. 2010-2019. Słownik Polszczyzny XVI wieku, Toruń-Wrocław, hasło: Cyrkut, http://spxvi.edu.pl/indeks/haslo/47124\#znaczenie-1 (dostęp 29.03.2019 r.).

Sokołowska Alina, Zalewska Antonina. 1958. Warszawa w rysunkach Aleksandra Majerskiego, Warszawa.

Sokołowska-Grzeszczyk Kazimiera. 1962. Ogród i pałac w Młocinach, „Rocznik Warszawski”, R. III, s. 124-148.

Sourcebook. 2013. Sourcebook for Garden Archaeology: Methods, Techniques, Interpretations and Field Examples, red. A.-A. Malek, Bern.

Spacerownik. 2009. Spacer drugi. Z Burakowa do pałacu w Młocinach, [w:] Spacerownik po Łomiankach, oprac. pod kier. E. Pustoły-Kozłowskiej, http://www.lomianki.pl/lomianki2/media/ 2011/04/3150_2_Z_Burakowa_do_palacu_w_Mlocinach.pdf (dostęp 21.02.2019 r.).

Sroczyńska Krystyna. 1964. Podwarszawskie rezydencje magnackie w obrazach Zygmunta Vogla, „Rocznik Muzeum Narodowego w Warszawie”, R. VIII, s. 345-376.

Sroczyńska Krystyna. 1969. Zygmunt Vogel, rysownik gabinetowy Stanisława Augusta, Wrocław.

Tołłoczko Zdzisława. 2016. Kostium francuski w architekturze XIX wieku i jego recepcja na ziemiach Polski na przykładzie pałaców w Świerklańcu i Kronenberga w Warszawie / French costume in architecture of the 19th century and its reception in Poland on examples of the palaces in Świerklaniec and of the Kronenbergs in Warsaw, „Wiadomości Konserwatorskie”, nr 48, s. $106-118$.

Waga A. 1843. O Janie Filipie Karozym (de Carosi) i Karolu Pertesie (de Perthées), dwóch naturalistach Polskich pod Stanisławem Augustem, „Biblioteka Warszawska”, t. 4, s. 193-210.

Weszpiński Paweł. 2007. Warszawa - obrazy z dziejów, Katalog wystawy - Muzeum Historyczne Miasta Warszawy czerwiec-lipiec 2007, Warszawa.

Załęski Krzysztof. 1998. Obóz Don Kichota — dekoracja do „fety” urządzonej w Młocinach, [w:] Ogród. Forma — symbol - marzenie, red. M. Szafrańska, Warszawa, s. 332, [ryc.] 227.

Zieliński Jarosław. 2015. Bielany. Przewodnik historyczny, Warszawa (rozdział 7: Zabytki, podrozdział: Mtociny, s. 211-224).

Żabicki Jacek. 2010. Leksykon architektury Mazowsza i Podlasia, Warszawa (hasło: Warszawa-Bielany, s. 254-255).

From research on the history of country residences near Warsaw.

The precincts of the Brühl family palace in Młociny

(from the mid-18th century)

The palace in the village of Młociny near Warsaw was part of a large early-modern complex, including a park, outhouses and outbuildings, as well as gardens on the bank of the Vistula, decorative pavilions, a game park, an inn and a windmill. It was the most northward residential complex of this type along the Warsaw Embankment. It did not survive long in its most extensive form, as it started to be reshaped at the end of the 18th c., which led to its degradation. 
The article discusses structures that were part of the Młociny palace-and-garden design and had various functions (some were used as living quarters, some for leisure pursuits and entertaining guests, some were purely decorative). Various available data were collected, including written and iconographic sources, archival maps and photographs, results of excavations from 2010 and of non-destructive research (an analysis of numerical models of the area generated by the GIS software). Correlating data from all those sources made it possible to the characterize the buildings and trace their histories from the design through the construction to the gradual destruction, as well as localize and identify those that have disappeared completely.

The oldest structures, designed by Johann Friedrich Knöbl and constructed in the years 1748-1763, when the palace in Młociny was owned by Henryk Brühl, were three wooden outhouses and a brick kitchen, probably a palisade-pergola on the courtyard, a neighbouring home farm with a brickyard, a game park with a pheasantry, a massive gate facing the south, a forest theatre and a temple of Diana. The next owner, Alojzy Fryderyk Brühl, who employed the architect Szymon Bogumił Zug, probably commissioned most of the decorative pavilions on the riverbank and some utility buildings, constructed in the years 1772-1784. These were brick outhouses, some small outbuildings (?), a new pillared gate, an Oriental pavilion, a monopteros (gloriette), two "peasant cottages", a "fisherman's cottage", alias hermitage, an inn and a windmill. Most of those garden structures did not survive beyond the mid-19th century. The complex was largely transformed and some of its 18th-century elements were rebuilt at the beginning of the 20th c., when the palace with its closest surroundings was taken over by Stefan Grodzicki. The elements reconstructed at that time were the outhouses, whose usable floor space was extended, the small neighbouring buildings, which were turned into living quarters, and - partly - the palisades. A new greenhouse, stable and barn were built, while the garden wall was modernized to make a passage to the courtyard.

Excavations on the plot to the south of the palace revealed relics of some of those structures, i.e. the outhouses further from the palace, the neighbouring outbuildings, the palisades-pergoles, the gates and the passage. An analysis of the sources resulted in establishing the approximate location of the 18th-century home-farm buildings and brickyard. A comparison of Zygmunt Vogel's watercolour A View of Mlociny with 19th-century maps helped to identify the location of the possible remains of the structures visible in the painting but non-existent now: the inn and the Oriental pavilion. A thorough analysis of the archival cartographic sources and their integration with the numerical model of the area revealed remnants of two islands in the game park, on one of which there used to be some buildings in the mid-18th c.

The buildings described above were integral parts of the residential complex in Młociny and had varied functions, which influenced their varied form and character. In most cases, as far as it can be established on the basis of the available sources, their form was determined by a coherent architectural vision reflecting current trends in designing palace-and-garden complexes. The Młociny complex was shaped mostly by the two architects commissioned by the owners, Johann Friedrich Knöbel i Szymon Bogumił Zug, whose work survived for less than a century. Most credit goes to Zug, whose artistic vision was fully implemented here, with eclectic solutions characteristic of his designs integrated into the Vistula landscape. Due to its coherent design and varied details, the Młociny complex can rival larger grandiose magnate residences of that epoch located in Warsaw or nearby.

Translated by Izabela Szymańska 


\begin{abstract}
ANEKS*
Oryginał: Archiwum Główne Akt Dawnych w Warszawie, Archiwum Skarbu Koronnego LVI, Inwentarze Starostw, jednostka nr 304, nr mikr. 2915, s. 67-71.

W edycji inwentarza zmodernizowano pisownię i interpunkcję według instrukcji wydawniczej dla źródeł nowożytnycha.
\end{abstract}

[s.] 67

Inwentarz wsi Młocin w województwie mazowieckim ziemi warszawskiej leżacej, który mnie niżej podpisanemu listem podawczem w Warszawie na Komisyi Rzepltej Skarbu Koronnego dnia 25 miesiaca lutego roku pańskiego 1765 wyszłym do spisania zalecony dnia ósmego marca roku 1765 infundo $^{\mathrm{b}}$ spisany

Ta wieś leży o milę od Warszawy nad Wisłą, na gruntach dobry[ch], pole hojne, w której poddanych jako i Burakowie do tejże wioski należący[ch] gospodarzów osiadłych jedynastu, ma pola taż wieś włók dziesięć. Powinnoś[ć] poddanyc[h], mają robić ciż poddani cały dzień, dwa dni męskie lub kobiece.

I tak powinni corocznie trzy odprawiać, straż kolejną czynić.

Czynszu corocznie na Święty Marcin po groszy 12 wypłacać powinni, drew fur dwanaście każdy corocznie jest przywozić obligowany,

połowę gęsi także do dwory dać, kapłonów trzy,

jajec piętnaście.

\title{
Opisanie Palacu
}

Najwprzód jadąc z Warszawy grobla z piasku usypana, przy której lipy dwiema rzędami sadzone, po prawej stronie ulicy w szpaler, grabowem drzewem sadzona ulica do bramy idąca.

Wjazd alias brama podwójna w słupach na zawiasach i hakach potrójnych, idąc od bramy po prawej ręce fu[rt]ka takaż, od której palisadów w słupach murowanych przęseł pięć, przy których

oficyna, od której wchodząc sień, do niej drzwi podwójne fasowane, na zawiasach ejsowych i hakach z zamkiem, kluczem, hantabami i suffryglami[?], nad którem okno o dwóch kwaterach w ramach dębowych w ołów oprawne z prętami, dobre. Pułap z tarcic płótnem wybity. Posadzka z cegły. Z sieni po prawej ręce

pokój pierwszy do niego drzwi podwójne fasowane na zawiasach essowych i hakach z zamkiem, kluczem, hantabami i suffryglami[?], w nim okno krzyżowe futrowane o czterych kwaterach w ramach dębowych w ołów oprawne, na zawiasach, haczykach z zakładkami, prętami, do niego okiennica z nadworza podwójna na zawiasach. Komin murowany kapiasty, pułap z tarcic płótnem obity. Podłoga $\mathrm{z}$ tarcic heblowanych. $\mathrm{Z}$ tego pokoju

pokój drugi, do niego drzwi pojedynczych na zawiasach podwójnych dwoje, w nim okna krzyżowe futrowane o czterech kwaterach w ramach dębowych w ołów oprawne na zawiasach, hacz[y]kach z okiennicami. Komin murowany kapiasty. Pułap z tarcic płótnem wybity. Podłoga z tarcic heblowanych, z którego pokoju

* Za pomoc w przygotowaniu edycji tekstu oraz w tłumaczeniu wyrażeń łacińskich dziękujemy mgr. Maciejowi Radomskiemu z IAE PAN.

a Lepszy K. 1953.

b Tłum.: gruntownie. 
sala do niej drzwi podw[ó]jne fajsowane na zawiasach essowanych i hakach z zamkiem w niej. Okien krzyżowych futrowanych o czterych każde kwaterach, dwa dobrych, do nich okiennice podwójne, drzwi do nich podwójne fassowane, podłoga $\mathrm{z}$ tarcic, pułap płótnem obity. $\mathrm{Z}$ sali pokój trzeci, do niego drzwi podwójne fasowane

na zawiasach essowych i hakach z zamkiem, w nim okna o czterych kwaterach z zawiaskami ze wszystkim dobre, okiennica $\mathrm{z}$ dworu podwójna, pułap płótnem wybity i podłoga $\mathrm{z}$ tarcic. $\mathrm{Z}$ tego pokoju

pokój czwarty, do niego drzwi pojedynczych z hantabami dwoje, w nim okno krzyżowe futrowane o czterych kwaterach w ołów oprawne, okiennica do niego z dworu podwójna, pułap płótnem wybity, podłoga $\mathrm{z}$ tarcic. $\mathrm{Z}$ tego pokoju drzwi do sieni podwójne fajsowane na zawiasach podwójnych.

Ta oficyna na fundamencie murowanym, $\mathrm{z}$ drzewa tartego postawiona, na której dach gontami czerwono malowanemi pobity. Od tej oficyny dalej idąc po prawej ręce palisadów podmurowanych przęseł 10, w których brama takaż podwójna w cyrkuł u wierchu dana, przy której furtka takaż. Przy tych palisadach

oficyna, do której wchodząc z sieni drzwi podwójne fajsowane na zawiasach ejsowych z zamkiem, kluczem, okno w niej o dwóch kwaterach w ołów oprawne dobre, dach, czyli pułap na zakładkę. Z sieni po prawej ręce

pokój pierwszy, do niego drzwi pojedyncze fasowane na zawiasach ejsowych z zamkiem, kluczem i hantabami w nim. Okno cum omnibus requisitis ut supra ${ }^{\mathrm{c}}$ dobre. Do niego okiennica podwójna dobra na zawiasach. Komin murowany kapiasty, pułap na zakładkę, podłoga z tarcic. $\mathrm{Z}$ tego pokoju

pokój drugi, do niego drzwi pojedynczych na zawiasach podwójnych $\mathrm{z}$ antabami dwoje, w nim okno krzyżowe futrowane o czterech kwaterach, do niego okiennica znadworna. Podłoga $\mathrm{w}$ nim $\mathrm{z}$ tarcic, pułap $\mathrm{z}$ tarcic na zakładkę. $\mathrm{Z}$ tego pokoju

sala, do niej drzwi pojedyncze fajsowane na zawiasach ejsowych z zamkiem, kluczem, w nim okien o czterech kwaterach z haczykami i innemi [?]ytami dwa dobrych. Okiennice podwójne znadworza, pułap na zakładkę, podłoga z tarcic. Drzwi do sieni fajsowane pojedyncze za zawiasach ejsowych. $Z$ tej sali

pokój trzeci, do niego drzwi pojedyncze fajsowane na zawiasach ejsowych, z zamkiem, kluczem i hantabami, w nim okno jedne o czterech kwaterach, dobre. Do niego okiennica znadworza, pułap na zakładkę i podłoga z tarcic. Z tego pokoju pokój czwarty. Do niego drzwi pojedynczych na zawiasach podwójnych dwoje, w nim okno krzyżowe futrowane jedno o czterech kwaterach, do niego okiennica podwójna na zawiasach.

Ta oficyna na fundamencie murowanym z drzewa tartego postawiona, na której dach gontami czerwono malowanymi pobity, od której oficyny dalej idąc palisadów podmurowanych przęseł pięć, przy których

oficyna, do której wchodząc drzwi podwójne fajsowane za zawiasach ejsowych z zamkiem i kluczem, nad nim okno o dwóch kwaterach. Pułap za zakładkę z tarcic, posadzka z cegły, z tej sieni po obu stronach izbów cztery, do nich drzwi podwójne fajsowane na zawiasach ejsowych, w nich okien krzyżowych na zawiaskach o czterech kwaterach. W nim pułapy za zakładkę, podłogi z tarcic.

Ta oficyna na fundamencie murowanym $z$ drewna tartego postawiona, dach na niej gontami czerwono malowanymi pobity. Od tej oficyny idąc dalej na lewą rękę palisadów podmurowanych w słup przęseł dziesięć, przy tych palisadach

kuchnia, do której z dziedzińca drzwi ślepe malowane, przy których schodki z balów sosnowych podmurowane.

c Tłum.: ze wszystkimi potrzebnymi rzeczami jak wyżej. 
Do tej zaś kuchni zaschody z boku od ogroda, do której drzwi podwójne fasowane na zawiasach ejsowych, w niej po prawej ręce izdebka.

Izdebka do niej drzwi pojedyncze za zawiasach hakowych, w niej okno krzyżowe o czterech kwaterach w ramach dębowych jedno. Sufit gipsowy, posadzka z cegły, przy tej izdebce w kuchni okien krzyżowych o czterech kwaterach dwie, przy oknach w kuchni.

piekarnia do niej drzwi pojedyncze fajsowane na zawiasach ejsowych, z zamkiem, kluczem i hantabą w niej. Okno krzyżowe o czterech kwaterach. Sionka, do której drzwi pojedyncze dębowe, w niej okno krzyżowe o czterych kwaterach.

Piwnica, do której uchody z balów dębowych, w niej komórek trzy, ta piwnica z gruntu murowana, na której dach karpiówką pobity.

\section{Palac}

Sień do niej drzwi podwójne fasowane dębowe na zawiasach ejsowych, z za[m]kiem, kluczem i hantabami, nad któremi okno stoczyste[?] o dwóch kwaterach w drzewo osadzone, cała sień malowana. Z sieni po prawej ręce

garderoba, do niej drzwi podwójne fasowane sosnowe przerżnięte, na zawiasach ejsowych, w niej okien dwa na zawiaskach, o czterech każde kwaterach. Z tej garderoby

pokój pierwszy, do niego drzwi pojedynczych dwoje na zawiasach ejsowych i hakach, w nim okien krzyżowych o czterych każde kwaterach dwa, do nich okiennice sosnowe, posadzka sosnowa. $Z$ tego pokoju gabinet.

Gabinet do niego drzwi sosnowe podwójne fasowane na zawiasach, w nim okno krzyżowe o czterych kwaterach dobre, posadzka sosnowa w taflach. Z tego gabinetu przedpokój, sala do niej, drzwi z pokoju sosnowe podwójne fasowane, na zawias[a]ch francuskich, w niej okien w balustradę danych trzy, do niech okiennice sosnowe w cztery każda składane sztuki, posadzka taflowa sosnowa. $Z$ tej sali po lewej ręce

przedpokój do niego drzwi sosnowe podwójne fasowane, na zawiasach ejsowych i hakach z zamkami, w niej okien dwa krzyżowych o czterech każda kwaterach, drzwi do sieni sosnowe, podwójne, fasowane, na zawiasach ejsowych. Ten cały przedpokój malowany.

Pokój drugi stołowy do niego drzwi z przedpokoju sosnowe podwójne fasowane na zawiasach ejsowych, okien w nim trzy o czterych każda kwaterach dobrych, okiennice do nich sosnowe podwójne, podłoga z tarcic heblowanych. Cały ten pokój malowany.

Pokój trzeci do niego drzwi z sali sosnowe podwójne fasowane, na zawiasach francuskich, w nim okien dwa o czt[e]rych każdy kwaterach, okiennice z pokoju we cztery składane. $Z$ tego pokoju

gabinet do niego drzwi sosnowe podwójne fasowane na zawiasach francuskich z zamkiem, w nim okno krzyżowe o czterech kwaterach, posadzka sosnowa o małych taflach. Z tego gabinetu przez pokój po prawej ręce

garderoba do niej drzwi z pokoju pojedynczych

sosnowych fasowanych dwoje, pierwsze na zawiasach francuskich z antabami, drugie na zawiasach ejsowych i hakach z zamkiem, kluczem, antabami, w niej okno krzyżowe o czterech kwaterach jedno dobre, podłoga $\mathrm{z}$ tarcic.

Sionka wąska przy kredensie, do której drzwi sosnowe pojedyncze fasowane na zawiasach ejsowych, w nim okno krzyżowe o czterech kwaterach jedne. Z tej sionki

sień do niej drzwi sosnowe pojedyncze fasowane, na zawiasach ejsowych i hakach, w niej okien krzyżowych o czterych każde kwaterach dwie, z sieni 
kred[e]ns fensztowany[?], do niego drzwi sosnowe pojedyncze fasowane, na zawiasach ejsowych i hakach, w nim okno jedno o dwóch kwaterach.

Ten pałac z gruntu murowany, na których dach dachówką karpiówką pokryty, rur blaszanych po rogach i kątach sześć, dymników w dachu pięć.

Ogród szpalerami i różnemi drzewkami wysadzany, ogród drugi na boku wsi nowo zasadzony drzewkami, ogród trzeci mniejszy do grobli się ciągnący.

Folwark na boku pałacu, do którego wchodząc od kuchni sień, do niej drzwi na przestrzał, drzwi pojedynczych sosnowych, z tej sieni po prawej ręce

izba do niej drzwi sosnowe pojedyncze na zawiasach, hakach, w niej okien w ołów oprawnych dwa, pułap na zakładkę, podłoga $\mathrm{z}$ tarcic. $Z$ tej izby

komora, do niej drzwi sosnowe pojedyncze na zawiasach $z$ hakami, w niej okien dwa, okiennica $\mathrm{z}$ dwora do jednego okna, pułap na zakładkę, podłoga $\mathrm{z}$ tarci[c], z sieni na lewej ręce izba.

Izba druga do niej drzwi sosnowe pojedyncze na zawiasach, hakach, w niej okien o dwóch każde kwadratowych dwa.

$\mathrm{Z}$ izby komora, do niej drzwi sosnowe na zawiasach, hakach, w niej okno jedne, okiennica $\mathrm{z}$ dworu sosnowa.

Kurnik do niego drzwi sosnowe pojedyncze na zawiasach, hakach, dobry. Piwnica murowana do niej drzwi na wadze, u tej piwnicy okien jedno przy izbie.

Wozownia do niej drzwi z dworu podwójne sosn[o]we, u niej pułap z tarcic.

Stajnia do niej wchodząc po mostku drzwi sosnowe pojedyncze, nad któremi okno w ołów oprawione. Ten folwark cały na fundamentach murowanych, $\mathrm{z}$ drzewa tartego w węgły postawiony.

\section{KARCZMA}

Pod górą za ogrodem, do której wchodząc

sień do niej drzwi pojedyncze sosnowe na zawiasach, hakach, z klamką, hantabą, ryglem i skoblami, u niej pułap na zakładkę. Z sieni po prawej ręce

izba do niej drzwi sosnowe pojedyncze na zawiasach, hakach, z zamkiem, kluczem, hantabami, w niej okien dwa o dwóch każde kwaterach pięć dobrych, pułap na zakładkę i podłoga z tarcic.

Alkierz do niego drzwi sosnowe pojedyncze sosnowe, na zawiasach, hakach, okien o dwu każda kwaterach dobrych dwa, do nich okiennice $\mathrm{z}$ dworu, podłoga $\mathrm{z}$ tarcic. Z tego alkierza kuchnia, do niej drzwi pojedyncze sosnowe na zawiasach, hakach, z zamkiem, hakiem i hantaby.

Piwnica murowana, do niej drzwi pojedyncze sosnowe, wschody do niej stare niedobre. Po lewej ręce

izba szynkownia, do niej drzwi pojedyncze sosnowe na zawiasach, hakach, w niej okien dwa o dwóch każde kwaterach. $Z$ tej izby

alkierz do niego drzwi sosnowe pojedyncze na zawiasach, hakach, okno jedno o dwóch kwaterach. Z k[u]chni wschody na górę $\mathrm{w}$ trepów 13, na której

komórka do niej drzwi na zawiasach, hakach, od stajni zabicie z tarcic, przy izbie od drogi wschody na ganek w trepów 12, u których drzwi na zawiasach. Z tego ganku

sala do niej drzwi z ganku pojedyncze na zawiasach, hakach, w niej okien o dwóch każde kwaterach pięć. Przy izbie szynkownej

stajnia do niej wrót na przestrzał podwójnych za zawiasach dwoje. Ta karczma z drzewa tartego w węgły, stajnia zaś w słupy, cała stajnia i karczma gontami pobita. Przy karczmie ogród chrustem ogrodzony, w którym pod gankiem ława jedna. 


\section{ZWIERZYNIEC}

Ex opposito ${ }^{\mathrm{d}}$ pałacu w kwadrat parkanem ogrodzony, do niego brama na przestrzał z wrzeciądzem, z skoblami, przy niej furtek dwie, w nim budynek z dwiema izbami i dwiema komorami. Ten zwierzyniec parkanem w słupy cały ogrodzony, in parte maiori ${ }^{\mathrm{e}}$ nadrujnowany.

\section{KARCZMA}

W Burakowie, do której wchodząc sień, do niej drzwi pojedyncze na zawiasach, hakach, z tej si[e]ni izba.

Izba do niej, drzwi pojedyncze na zawiasach, hakach, w niej okien o jednej każde kwaterze dwa. $Z$ tej izby

komora do niej drzwi pojedyncze na zawiasach, z wrzeciądzem i skoblami. Ta karczma z drzewa jest w słupy budowana, na której dach snopkami pokryty.

Ta wieś inkludując kresencyje i arendy jako mam de certis narratis ${ }^{\mathrm{f}}$ czyni razem z wsią Burakowem intraty rocznej zł 1000.

Który to inwentarz infundo supraspecificatas villas ${ }^{\mathrm{g}}$ spisawszy ręką własną podpisuję

Krzysztof Frankowski, burg[rabia] grodzki warsz[awski] manu propria ${ }^{\mathrm{h}}$.

Inwentarz niniejszy wsi Młocin jest na dnia 22 miesiąca października roku pańskiego 1765 ad Archiwum Economium Kommissyi Rzpltej do Skarbu Koronnego oddany.

\footnotetext{
d Tłum.: naprzeciwko.

e Tłum.: w większej części.

f Tłum.: szczegółowe dane.

g Tłum.: na miejscu w wyżej wymienionych wsiach.

h Tłum.: ręką własną.
} 